\title{
LOSS OF COOLANT: CONTROL OF CONSEQUENCE BY EMERGENCY CORE COOLING[a]
}

G. F. Brockett, Acrojet Nuclear Company

R. W. Ciriebe, Asrojel Nuclear Company $[$ lh
R. W. Shumway, Aerojet Nuclear.

J. O. Zane, Aerojet Nuclear Com

\section{INTRODUCTION}

For ccrtain postulaiced accidents in central-station nuclear power plants, engineered safety systems are mitigate potential consequences to both the public and the plant. These engineered safety systems are intended range of possible plant failures including the design basis accident (DBA) which, for certain liquid-cooled red postulated to result from a large rupture of one of the primary system coolant pipes. The pipe rupture and the $\mathrm{a}$ are identified as the loss-of-roolant accident ( $\mathrm{LOCA}$ ). This accident and its consequences are controlled $b$ emergency core cooling (ECC) systems which are standby auxiliary cooling systems.

'This paper is directed to the current state-oi-understanding of those factors which, as idertified by the analy repuirements for and the performance of emergency cooling systems. Emphasis is placed on light water-coole pressurized water and boiling water types. The approach taken, to detcrmining the design requirements 8 performanee, in general, is applicable to ofher reactor syslems having liquid coolant at elevated temperatures and

'The Lody of the paper is divided into three parts as follows: The first part (Section II) describes the proo ECCS performitlee criteria into design requirements and uses a "fault tree" technique to identify systematicafy analyzing the phenumena and system behavior in the LOCA which are important to the selection of EC. requiremints. The second part (Section III) presents "performance maps" of current emergency core cooling s] both pressurized and boiling water reactors. These performance maps are derived from postblowdown core he based on information obtained from experimental programs on emergency core cooling, metal-water reaction rat embrittlement. Part three (Section IV) presents a survey of the research and development, on an internation addressed to the various arcas of hydraulic, thermodynamic, and mechanical effects surrounding the performar core conling systems in light water-cooled reactors. The concluding section (Section V) summarizes the more i delermining the selection of ECC system design requirements. Additionally, the relevant research and devel planned and needed for improving the analytical base for ECC design and evaluation are cited.

Appendices are included which provide (a) a summary description of contemporary PWR and BWR primas and thu answeiatcd emergency core conling systems, and (b) a summary description of the loss-of-coolant process BCC for both PWR's and BWR's.

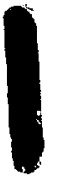

\section{FACTORS AFFECTING ECCS PERFORMANCE AND DESIGN REQUIREMENTS}

The basic rritcrion for limiting the consequenees of an L,OCA in contemporary light water-cooled reactor follows:

A reikelor core, in the unlikely event of a loss-of-roolant accident, must be maintained in a definable he.. transfor prometry iti order to assure the potential for continued removal of after-heat.

Sulseguen critcria can then bs derived that distute the upper limits for certain properties of reactor core material exiraled. ussure that the structural integrity of core internals is maintained. Property limits of core materials masimum lemperature, ind possibly time-al-temperuture, limits which the hotter regions of the core can be allowed 


\section{F COOLANT: CONTROL OF CONSEQUENCE BY EMERGENCY CORE COOLING[a]}
Company
Company $|1|$
R. W. Shumway, Aerojet Nuclear Company
J. O. Zane, Aerojet Nuclear Company

\section{INTRODUCTION}

central-station nuclear power plants, engineered safety systems are incorporated to e public and the piant. These engineered safety systems are intended to control a wide the design hasis accident (DBA) which, for certain liquid-cooled reactor systems, is one of the primary system coolant pipes. The pipe rupture and the subsequent events ent (LOCA). This accident and its consequences are controlled by the action of h are standby auxiliary cooling systems.

ate-of-understanding of those factors which, as identified by the analysis, influence the emergoncy cooling systems. Emphasis is placed on light water-cooled reactors of the s. The approach taken, to determining the design requirements and ECC system er reactor systrms having liquid coolant at elevated temperatures and pressures.

three parts as follows: The first part (Section II) describes the process of translatinge irements and uses a "fault tree" technique to identify systematically the key factors in havior in the LOCA which are important to the selection of ECC system design presents "performance maps" of current emergency core cooline system designs for s. These performance maps are derived from postblowdown core heatup calculations mental programs on emergency core cooling, metal-water reaction rates, and zirconium sents a survey of the research and development, on an international scale, which is thermodynamic, and meehanical effects surrounding the performance of emergeney reactors. The concluding section (Section V) summarizes the more important aspects design requirements. Additionally, the relevant research and development activities tical base for IECC design and evaluation are cited.

7f: (a) a sumnury description of contemporary PWR and BWR primary coolant circuits stems, and (b) a suminary description of the loss-of-eoolant process with the action of

\section{TING ECCS PERFORMANCE AND DESIGN REQUIREMENTS}

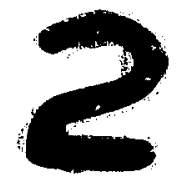




\section{INTRODUCTION}

For certain postulated accidents in central-stalion nuclear power plants, engineered safety systems ari mitigate polential consequences to both the public and the plant. These engineered safety systems are intended range of possible plant failures including the design basis accident (DBA) which, for certain liquid-cooled 1 postulated to result from a large rupture of one of the primary system coolant pipes. The pipe rupture and the are identified as the loss-of-eoolant accident (LOCA). This accident and its consequences are controlled emergency core coolme (ECC) systems which are standby auxiliary cooling systems.

This paper is directed to the current state-of -understanding of those factors which, as identified by the anal requircuents for and the performance of emergency cooling systems. Emphasis is placed on light water-coole pressurized water and boiling water lypes. The approach taken, to determining the design requirements preformanee, in general, is applicable to other reactor systems having liquid coolant at slevated temperatures and

The body of the paper is divided into three parts as follows: The first part (Section II) deseribes the proi ECCS performance criteria into design requireme'nts and uses a "fault tree" technique to identify systematically analyzing the phenomena and system behavior in the LOCA which are important to the selection of EC requirements. The secund part (Section III) presents "performance maps" of current emergency core cooling $\mathrm{g}$. both pressurized and boiling water reactors. These performance maps are derived from postblowdown core he based on information obtained from experimental programs on emergency core cooling, metal-water reaction rat embrittlement. Part three (Section IV) presents a survey of the research and development, on an internation addresend to the varions areas of hydraulic, thermodynamic, and mechanical effects surrounding the performar: core cooling systems in light water-cooled reactors. The concluding section (Section V) summarizes the more i determining the selection of ECC system design requirements. Additionally, the relevant rescarch and devel planne.i and needed for improving the analy tical base for ECC design and evaluation are cited.

Appendices are included which provide (a) a summary deseription of contemporary PWR and BWR primar. and tir atsociated curergency eore cooling systems, and (b) a summary deseription of the loss-of-coolant process $y$ ECC for both PWR's and BWR's.

\section{FACTORS AFFECTING ECCS PERFORMANCE AND DESIGN REQUIREMENTS}

Thu basic criterion for limiting the consequences of an I.OCA in contemporary light water-cooled reactorg follows:

A reactor core, in the unlikely event of a loss-of-coolant accident, must be maintained in a definable hea transier weometry iti urder lo alssure llee potential for continued removal of after-heat.

Sulsecfuent eriteriu can then be derived that dictute t!e upper linits for certain properties of reactor rore materi "xceceded, assure that the structuril integrity of core infermals is maintained. Property limits of core material maximum l'mperature, and possibly lime-it-lemperature, limits which the hotter regions of the core can be allowe

[a] Nork performed under auspiens of the Unitrd States Alomic Energy Commission under Contract No. An (î0

[b] Currently with Encrgy Incorporated, Idaho falls, Idaho.

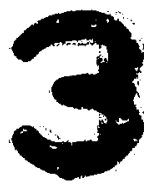




\section{INTRODUCTION}

ation nuclear power plants, engineered safety systems are incorporated to ind the plant. These engineered safety systems are intended to control a wide I hasis accident (DBA) which, for certain liquid-cooled reactor systems, is he primary system coolant pipes. The pipe rupture and the subsequenl events A). This accident and its consequenees are controlled by the action of dby auxiliary cooling systems.

ferstainding of those factors whin h, as identified by the ainalysis, influence the y cooling systems. Emphasis is placed on light water-cooled reactors of the "pproseh caken, to determining the design requirements and ECC system systems having liquid coolant at elevated temperatures and pressures.

arts as follows: The first part (Section II) deseribes the process of translating fand uses a "fault tree" technique to identify systematically the key factor: in the LOCA which are important to the selection of ECC system design "performance maps" of current emergency core cooling system designs for performance maps are derived from postblowdown core heatup calculations fograms on emergency core cooling, metal-water reaction rates, and zirconium urvey of the research and development, on an international scalc, which is dynamic, and mechanical effects surrounding the performance of emergency The concluding section (Section V) summarizes the more important aspects equirements. Additionally, the relevant research and development activitics for ECC design and evvaluation are cited.

Inmmary description of contemporary PWR and BWP primary coolant rircuits hd (b) a summary description of the loss-of-roolant process with the action of

\section{CS PERFORMANCE AND DESIGN REQUIREMENTS}

es of an LOCA in contemporary light water-cooled reactors may be stated as

-of-coolant accident, must be maintained in a definable heat

al for continued removal of after-hcat.

the upper limits for certain properties of reactor core materials which, if not fr int(ruals is maintained. Property limits of core materials in turn dictate fure, limits which the hotter regions of the core can be allowed to reach.

tates Atomic Energy Commission under Contract No. AT(10-1)1375. Talls, Idaho.

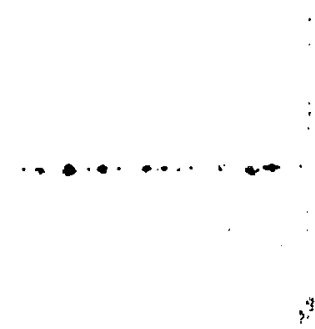




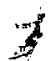

These erileria must be reduced to prerlormaner and funclional design requirements for removal of a speeifie sensible he al from the reaclor core by auxiliary cooling. 'I'his section reviews the prencesses which could be used by the translate the performance requirements into functional requirements and ultimately into suit able: FCC system design ro

The first step in the transhation process would be for the designer to evaluate bOC $\Lambda$ thermal-hydraulic beh? partieular plant design in order to intermine the demand requirements for ECC. These evaluations would be perform? range of break sizes and locations will partieular emphasis on the influene that the blowdown hydraulic forces migh" effretiveness of the emergency core eoolant. In these evaluations, the designer would obtain the histories of the me and the fluid stites in the rore by using digital computer codes that are capable of tracking the mass, momentum redistribut ion of the coelant as the system depressurizes. The core flow rate and the siate of the fluid at the core inle be tsed in addlitionai calculations of the core thermal response to determine the extent to which the energy generate within the fuel is translierred to the coolant. The core thermal response: calculations would produce histories of temperalure.

These claulding lemperature histories, oht ained for a variety of assumed primary system ruptures, would provid

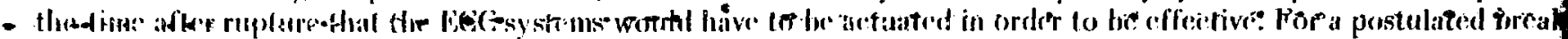

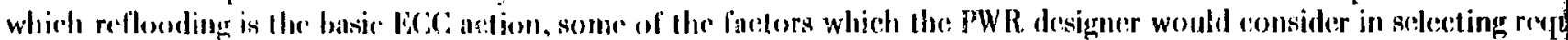
an LCC: system are the following:

(1) The rladeling femprerature and rate of temperature rise in the latter phase of blowdown prior to reflowtiing

(2) The volume and injelion rate of water which must be supplied to fill the lower plenum and initiate core: reflooding al il prescribed time

(3) The magnitude and duration of system decompression forces which could act on the injected water and prevent it from reaching the iower plenum

(4) Cort thermal bethavior once reflooding is initiated, and also the potential system effects which permit or inhibit the design flooding rate to be achicved.

Acquisition of llis information with adequate precision to permit quantifieation of ECC effectiveness significant demantis on the completeness and correctness of the analysis methods used to characterize the thers processes occurring during a loss-of enolant accident with emergency core coolant injection. The analysis methe available to the designer have been partially verified by experiment in certain areas, and, as discussed in Section IV further efforl is being arldressed lo llor verification process.

'To assist in detormining the adrofuacy of ECC performance requirements developed using the current anal systematic investigations can bo condueted to determine whether uncertainties in the analysis methods col underpredietions of claddling temperalures, emergency coolant delivery rates, and heat removal rates. Such investiga be ronducled to show where improvements in the completeness and precision of the analysis will lead to quantifi potential conservatisns and margins in ECC system designs. Ultimately the refinement and experimental verifi analysis techniques can lead to an increased level of confidence in the determination of (a) the adequacy of ECC sy? existence of margins and (b) the potential for unnecded system complexity which could be a causative factor in accid

As an illustration of prohing the uncertaintics in the analysis techriques a fault tree evaluation method has exhibit the potential for crror in the modeling methods which could lead to an erroneous eonclusion on re performanre. The Irec presented was grenerated for discussion purposes and is only developed to the level neede sperific rlements of the analysis. In general, grealer detail is provided for those elements of the tree within the time LOCA in which BCC: artion is involverl.

Since cach plant design responds somewhat differently to a particular pipe break area during a postulated LOCA type of plant and pipe brrak wis necessarily selected for the study. The example fault tree developed applies to a typ PWVIt planl mubjocted to the hypothelie al design basis aceident which for this plant is a double-ended break in an inlet

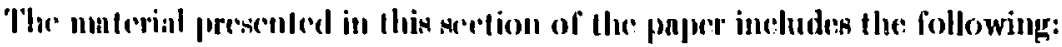

(1) limult Irece altrilnuter, lengie, and sy mboslism

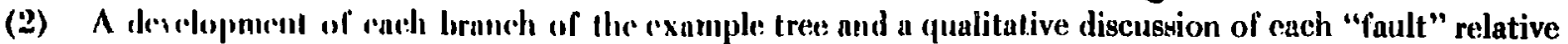
lo ils potcontial for enusing a signifient error in analysis results 
(3) Comments on the magniturle of the error required to cause an unexpected violation of the stated limits

(4) A summary of the overall PWR analysis fault tree identifying what appea a be the most significanth end faults for the tree?

(5) A discussion of how the example trec could be modified for application to analysis of a BWR.

\section{FAULT TRER ATTRIBUTES, LOGIC, AND SYMBOI,JSM}

Spreifie altributes of lhe fatult trec evaluation method used in this paper to highlight the important face

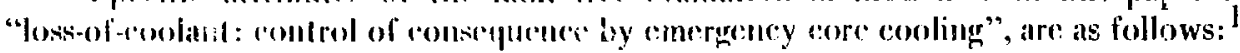

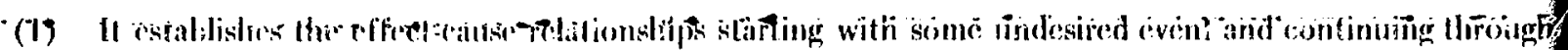

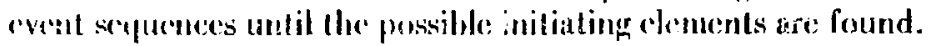

(2) It involves a deduetive sacth od of reasoning. Generally, the rules of divelopment are straightfor ward For a griven cvent, the conditions neeessiry to carse the event and those sufiticient to cause it ars reypuired.

(3) It involves a recorded process which uses logic symbology to show relationships in a form which? follows Boolean rules and relationships (basic laws of thought) and in the language of the system being: evaluated.

(4) It is a comminnication tool, expressed in terms of the system, understandable by designer and management alike.

Fault trec analysis is a systematic procedure that identifies and records the various combinations of con actions, or cvents that can result in a predefined system statc or undesired event. The development of a fault definition of an undesired condition. 'The system is then methodically analyzed to determine all the logical e functional fault events that can cause the undesired event. The principal contributory fault events are then furt establish the logical chain of subevents. All fault events are coupled through logic gates. Figure l summarizes the in construcling the tree and defines sureh of the logic gates.

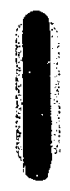

TYPICAL EXAMPLE OF A FAULT TREE FOR ANALYSIS OF THE DESIGN BASIS ACCIDENT IN A PWR

The top structure for an example PWR fault trec is shown in Figure 2. The undesired event is "analysis adequate ECC requirements-cladding temperature or embrittlement limits exceeded". The "and" gate and the immediately below the undesired event reflect the fact that the remainirg structure of the tree is developed to inves sources of errors in the analysis which is used to detcrmine the requirements for and the adequacy of ECC system design basis accident situation.

The investigation near the top of the tree was separated into analysis of events that would eause high claddir prior to core reflooding and analysis of events that would cause high temperatures after core reflooding is initiated places emphasis on two major aspects of an ECC system design-.first, the time in the accident seapuence at which $\mathrm{E}$ be initiated, and second, the effectiveness of the energy removal process once ECC action is initiated.

The five major branches of the: fault tree, shown on Figure 2, are developed individually in the remainder of general, carh branch of the tree is developed only to a level suitable for discussing potential ertors or deficie portione of the andysis. Onee the desired level is achieved the fasalt is shown as a diamond which indicat development of the Iree is required 10 define the primary faults. Each diamond is briefly discussed to provide an it rolevance of the identified event to ECC system design and performance requirements. The specific statenent evaluation of the behavior of a four-loop PWR during a design basis accident. The term "predicted" on the fanlt event or conclition that is based on the aceident concept portrayed by existing safety analysis codes. 
error required to ease: an uncxpected violation of the stated limits

lysis fault tree identifying what appear to be the most significant

could be modified for application to analysis of a BWR.

\section{MBOI.JSM}

Wation method used in this paper to highlight the important factors related to Furency core cooling", are as follows: 1

Inships starting with some andesired event and continuing thoough tialing dements are found.

asoning. Generally, the rules of development are straighlforward. vecessary to cause the event and those sufficient to cause: it are

ch uses logic symbology to show relationships in a form which ips (basic laws of thought) and in the language of the system being

essed in terms of the system, understandable by designer and

lure that identifies and records the various combinations of component states, ed system state or undesired event. The development of a fault tree begins with in then methodically analyzed to determine all the Iogital combinations of sired event. The principal contributory fault events are then further analyzed to tevents are coupled through logie gates. Figure: I summarizes the symbolism usted byic gates.

\section{LL EXAMPLE OF A FAULT TKEE FOR F THE DEGIGN BASIS ACCIDENT IN A PWR}

Tault tree is shown in Figure 2. The undesired event is "analysis fails to identify ure or embrittlement limits exceeded". The "and" gate and the two "houses" e fact thit the remaining structure of the tree is developed to investigate potential determine the requirements for and the adequacy of ECC system designs given a

was separated into analysis of events that would cause high cladding temperatures hat would cause high temperatures after core reflooding is initiated. This approach system design-first, the time in the accident sequence at which ECC, action must energy removal process once ECC action is initiated.

shown on Figure 2, are developed individually in the remainder of this section. In Only to a level suitable for discussing potential errors or deficiencies in specific orl is aclieved the fault is shown as a diamond which indicates that further primary faults. Each diamond is briefly discussed to provide an indication of the Im design and performance requirements. The specific statements are based on Juring a design basis accident. The term "predicted" on the fault tree indicates an oncept portrayed by existing safety analysis codes. 


\section{EVENT REPRESENTATIONS}

The rectengle identifies on event that results from the combination of fault events through the input logic gote.

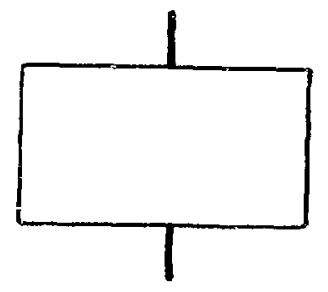

The circle describes a bosic fault event thot requires no further development. Frequency and mode of foilure of items so identified are derived from empirical data.

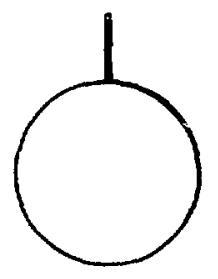

The triangles are used as transfer symbols. A line from the apex of the triongle indicates a transfer in and a line from the side denotes a transfer out.
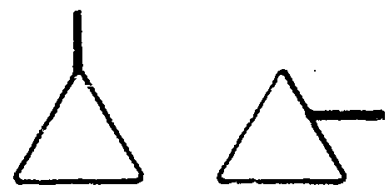

The diamond describes a foult event that is considered bosic in a given fault tree. The possible causes of the event ore not developed either becouse the event is of insufficient consequence or the necessary information is unevailable.
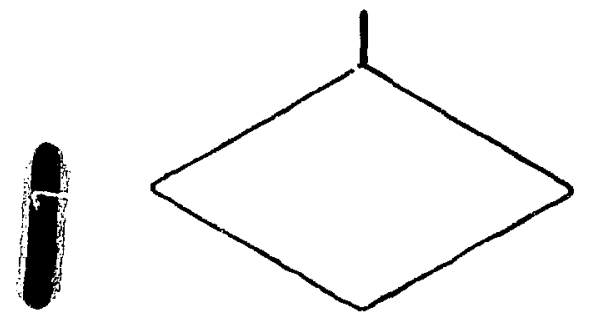

The house indicates an event that is: normaliv expected to occur.

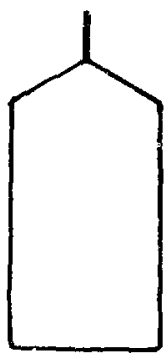

\section{LOGIC OPERATIONS}

The AND gate discribes the logical operation whereby the coexistence o oll input events is raquired to produ. ine output evant.

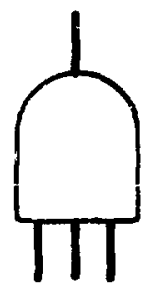

The OR gate defines the situation whereby the output event will exist if one or more of the input event exists.

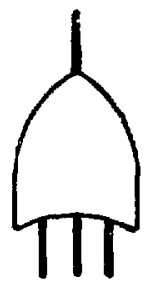

The INHIBIT gote describes a causal relationship between one foult and another. The input event directly produces the output event if the indicated condition is sotisfied. The condifional input defines a stat of the system thot permits the fault sequence to occur, and may be eith normal to the system or results fron feilures.

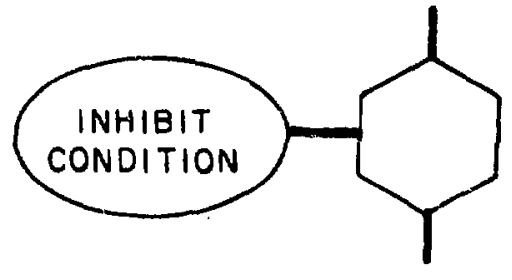

ANC $-A-929-H$ 
ent thai

fault

gate.

fault event opment.

of items in empirical
The house indicates an event thot is normally expected to occur.

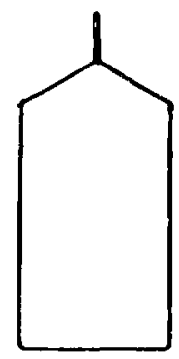

LOGIC OPERATIONS

The AND gate discribes the logical operation whereby the coexistence of all input events is required to produce the output event.

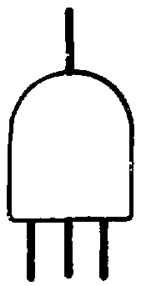

The OR gate defines the situation whereby the output event will exist if one or more of the input event exists.

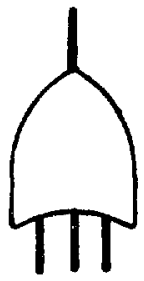

sfer symbols.

riangle

line from

.

vent that

it tree.

it are

he event

or the

lable.
The INHIBIT gate describes a cousal relationship between one fault and onother. The input event directly produces the output event if the indicoted condition is sotisfied. The conditional input defines a state of the system that permits the fault sequence to occur, and may be either normal to the system or results from failures.

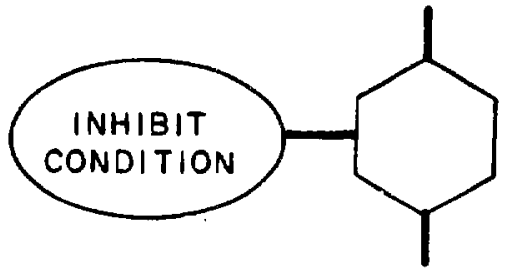

ANC $-A-929-H$

Fig. 1 Fault tree symbolism. 


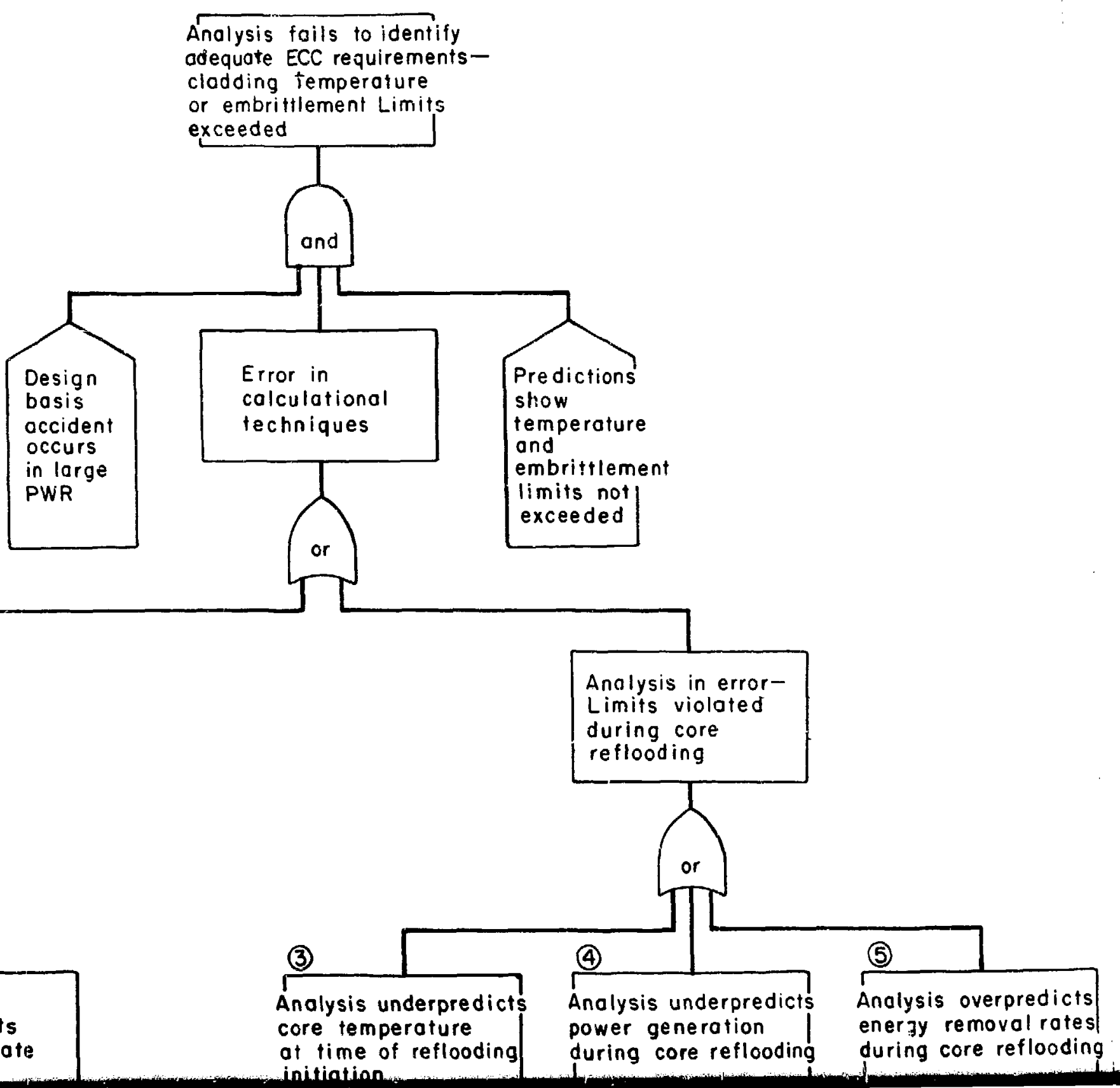




\section{(1)}

Analysis overpredicts

energy removal rates

or underpredicts

stored energy

\section{(2)}

Analysis

underpredicts

time to initiote

reflooding

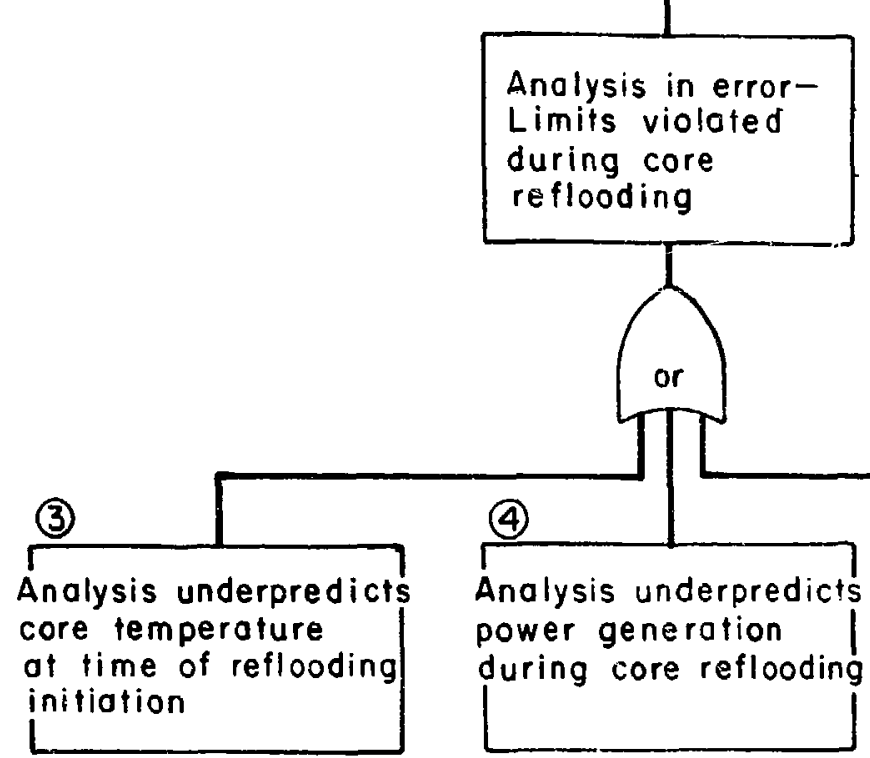

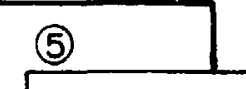

Anolysis overpredicts energy removal rates during core reflooding I

$A N C-B-930-H$

Fig. 2 Tree development for cladding temperature or embrittlement limits exceeded because analysis fails to identify adequate ECC requirements. 


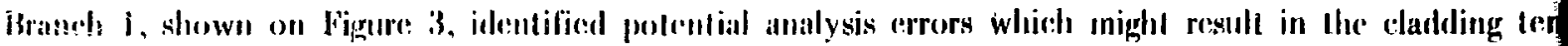
underpredieted prior to core reflooding. For the development of this branch the blowdown and refill tiones are: assu predicled.

This branch is not developed in extensive detail because large errors would have to exist in the analysis would occur and such errors are considered unlikely. Only potential faults associated with the analysis underpi generated or stored or overpredicting energy removal rales are shown. The period of interest for this branch is ab This period, based on current predictions, can be separalled into three equal time increments: (a) ten seconds fo depressurize 10600 psi, (2) ten seconds for the systcin to firlher depressurize to the containment pressure, and (3) ten seounds for the accumulators to refill the lower plenum after blowdown is complete. The expected maxim during lhis period is several hundred degrees Fahrenheit below the temperature limit; however the possibility do cladding temperature limit could loc exceeded. For example, if the energy stored within the fuel is as predicted, bi heal transfer oceurs, eladding temperatures potentially could rise to above $2500^{\circ} \mathrm{F}$ by the time reflooding is if wilhoul blowdown heat transfer, temperatures would reach about $2000^{\circ} \mathrm{F}$ in 4 or 5 seconds as a result redistribution in the fuel rod. After this time, a relative!y slow heatup rate exists which is primarily dependen: generation. $\Lambda t$ about 30 seconds after rupture the adiabitic heatup rate is about $20^{\circ} \mathrm{F} / \mathrm{sec}$ in the high-power densi renctor core.

(11 Ihe left sidir of Jigure 3 under "analysis overpredicts blowdown heat trangfer" the Iree is terminated wi "analysis overprediets surface: heat Iransfer eocefiecients". If the Iree had been developed further the following po the analysis woild have been included:

(1) Analysis overpredicts the lime to CHF

(2) Analysis overpredicts lacat transfer during transition boiling

(3) Analysis overpredicts energy removal rafes during the period when film boiling and convectios correlations are applied.

Development of the tree below cach of the various heat transfer processes noted would have reflected crrors re inapplicability of the correlations to a transient environment or from errors in the calculation of core mass flow re Frrors it core nass flow rate or fluid state calculations may result from errors in the break flow model, the $p$ hydraulic resistance model, or the steam generator model, and from errors in calculatlons of the flow maldistribut flow or biockage.

Scnsitivity studies are either not available or not sufficiently complete to quantify the magnitude of the calculalions whic!l would be required to causv: a fault on Branch 1 due to analysis errors associated with the di overpredicts surface herat Iransfer coefficients". Ilowever, the anthors' opinion is that for this fault to occur act cocficients used after core dryout would have to be at liast 30 to $40 \%$ less than predicted and the transition coc in the codes would have to be applied for a longer period of time than is actually appropriate, probably 30 to eurrently planned research programs, in the blowdown heat transfer area are expected to show that not only $i$ branch of the tree unlikely but that current analysis underpredicts blowdown heat transfer.

If the right side of Figure 3 under "analysis underpredicts stored energy or power generation rate" had further, the need to examine models or assunptions in the analysis associated with the following areas would evicient:

(1) Cinp condiarlunro:

(2) $\mathrm{HO}_{2}$ physical propertien (thermal coudurtivily and specific heat)

(i) Prorupture power densily

(4) Decay juwor gencrution rates.

I'ler anp conduelunce is probulbly the most influenlial und the most difficult parameler to quantify and, then

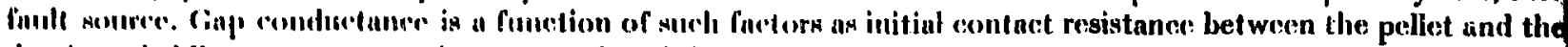

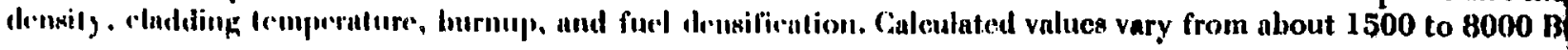


polential analysis errors which mighl result in the eladding lemperature beingr development of this branch the blowdown and refill times are assumed to occur as

e detail because large errors would have to exist in the analysis before this fault nlikely. Only potential faults associated with the analysis underpredicting energy moval rales are shown. The period of interest for this branch is about 30 seconds. be separalled into three equal time increments: (a) ten seceonds for the system to system to furlher depressurize to the containment pressure, and (3) approximately lower plenum after blowdown is complete. The expected maximum temperature: hrentocil below the lemperature limit; however the possibility does exist that the For exinnple, if the energy stored within the fuel is as predicted, but no blowdown tontially could rise to above $2500^{\circ} \mathrm{F}$ by the time reflooding is initiated. In fact, ss would reach about $2000^{\circ} \mathrm{F}$ in 4 or 5 seconds as a result of temperature a ribatively slow heatup rate exists which is primarily dependent on decay heat he adiahatic heatup rate is about $20^{\circ} \mathrm{F} / \mathrm{sec}$ in the high-power density regions of the

Gis overpredicls blowdown heat tranafer" the tree is terminated with the statement ficients". If the Iree had been developed further the following potential errors in

uring transition boiling

val rates during the period when film boiling and convection

ious heat transfer processes noted would have reflected errors resulting from the enviroument or from errors in the calculation of core mass flow rate or liuid state. lculations may result from errors in the break flow model, the pump model, the tor morkel, and from errors in calculatlons of the flow maldistribution due to cross

e or not sufficiently complete to quantify the magnitude of the orror in present a fault on Branch 1 due to analysis errors associated with the diamond "analysis However, the authors' opinion is that for this fault to occur actual heat transfer to be: al least 30 to $40 \%$ loss than predicted and the transition cooling correlations ger period of time than is actually appropriate, probably 30 to $40 \%$ longer. The pwdown heat transfer area are expected to show that not only is a fault on this yeis underpredicts blowdown heat transfer.

ysis underpredicts stored energy or power generation rate" had been developed ptions in the analysis associated with the following areas would have been male

hductivily and specific heat)

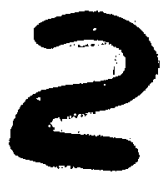

inflemenial and the most difficult parameter to quantify and, therefore, conld be a ycl, furlurs as initiul content resistance belween the pellet and the chadding, power drousilinulion. Calculated values vary from about 1500 to $8000 \mathrm{Btu} / \mathrm{hr}-\mathrm{ft}^{2}$."F; the 


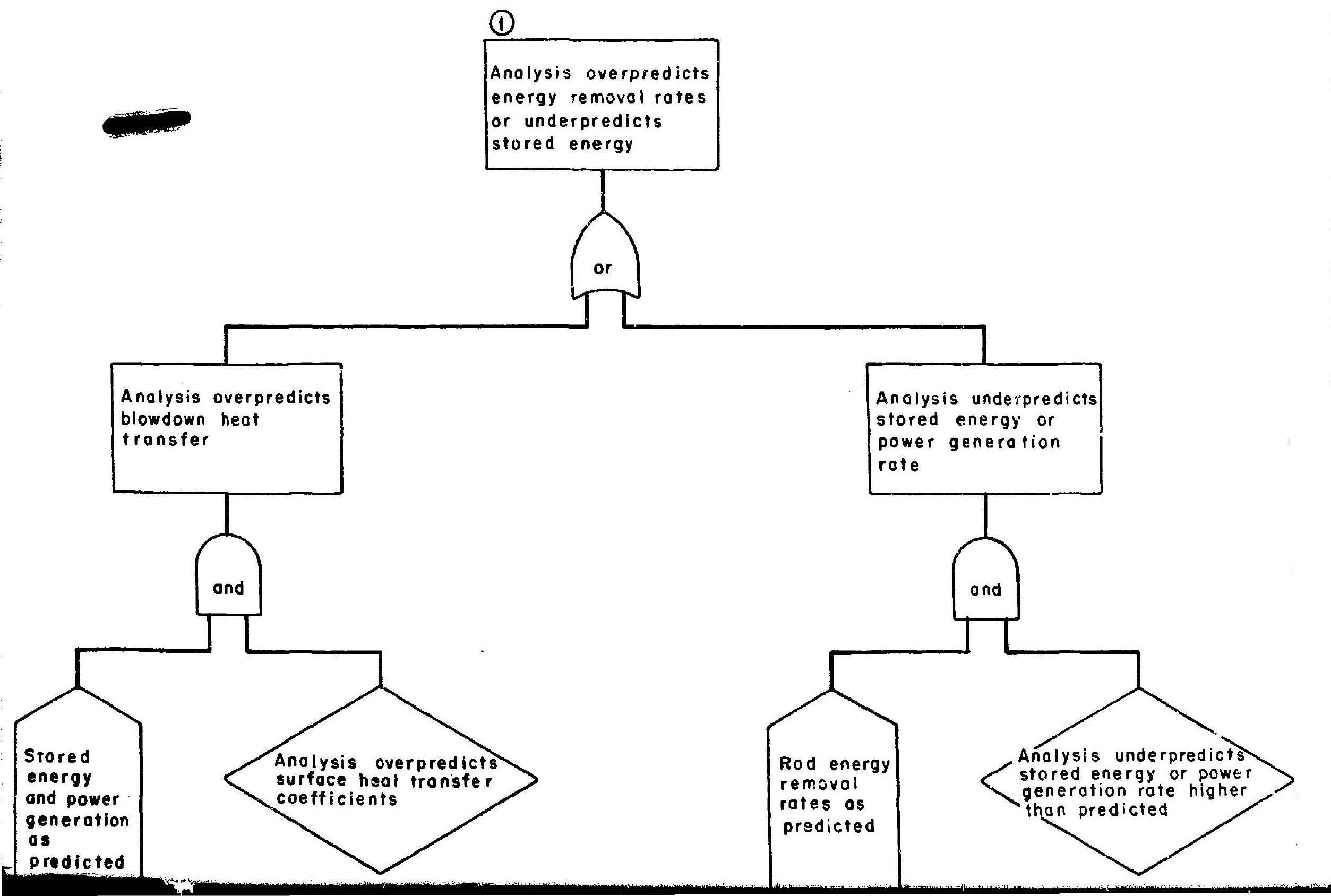


values are lowest at the beginning of life and increase with burnup. For the higher values, large changes have little effec as values drop to about $1500 \mathrm{Btu} / \mathrm{hr}-\mathrm{ft}^{2}{ }^{\circ} \mathrm{F}$, the time-temperature response of the cladding starts to be affected. believe that the analysis is not likely to underpredict the stored energy by more than $20 \%$ whick, is the minimum errot be needed to cause a fault on this branch of the tree. The early LOFT tests are expected to provide a basis for estab] bounds on the stored energy calculations and showing that the fault is indeed unlikely.

The houses on Figure 3 are shown to identify assumptions required to make the event chaine independent.

\section{Branch 2-ANAi,YSIS UNDERPREDIC'TS TIMF, TO INI'IIATE REFI.OODING}

This brameh of the tree, shown in Figure 4. addregses the problem of whether elements of the analysis co

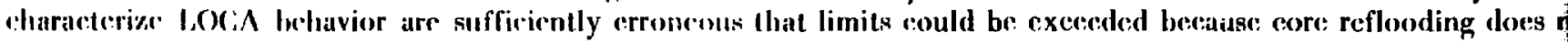
predictid. For this discussion the litowdown heat trausfor, prerupture stored energy, and decay power generation Branch 1) are assumed to occur as predicted. As would loc expected, clemonts on this branch include itcms related t reaches the lowar plenun and how fas! the vessel lower plenum could be filled by injection of the inventory in the ac The dianonds and the inhibit gate arc diseussed in the following subsections. The inhibit gate is used to emphasize t signilicant portion of the injected ECC. (40\% or more) bypasses the core and is expelled through the break during blo water level in the lower plenum and the blowdown time are not of particular significance to this fault.

(1) Analysis Overpredicts ccumulator Delivery Rate. For the particular type of plant and accident considered, three acrim intors, each with a nominal water volume of $850 \mathrm{ft}^{3}$, are assumed available. The fourlh accumulator, the one on the broken loop, is assumed to discharge into the containment. The nominal predicted discharge rate for the three accumulators is ahout $80 \mathrm{it}^{3} / \mathrm{sec}$. The predicted behavior is for the accumulators to fill the lower plenum, downcomer, and core bypass area which is connected to the downcomer (a total volume of about $1750 \mathrm{ft}^{3}$ ) in slightly more than 20 seconds after the blowdown is completed. The lower plenum would refill up to the bottom of the core in about 12 scconds after blowdown.

The analyses would overpredict the actual delivery rates if the hydraulic resistances bctween the accumulators and the primary systom are higher than assumed, or if the accumulator gas pressure or water volume is lower than assumed. To bie a significant problem on this branch of the tree, the error, in the author's opinion, would have to result in the predicted delivery rate being more than a factor of two greater than the actual accumulator delivery rate. $\Lambda$ reduction of the delivery rate by two from iliat predicted would introduce about a ten second delay in the time required to fill an empty lower plenum or, for an adiabatic heatup rate, permit the temperature to rise aboul $200^{\circ} \mathrm{F}$ higher than predicfed. Although extremely unlikely, a combination of elrors involving the prerupture accumulator water level, the coolant bypassing the core to the break during blowdown, and the length of the biowdown time could oceur such that, contrary to prediclions, the lower plenum does not fill before the accumulators are emptied. The time: would then be ample for temperature limits to be exceeded before the low pressure injection system (I,PIS) could raise the water level to the core bottom and initiute reflooding. The delivery ratr of the L.PIS, which is cight to ten times less than the delivery rate for the three accumulators, would be inadequate to prevent this fault.

(2) Analysis Underpredicts ECC Bypass lo the Break During Blowdou'n. The possibility exists that mechanisins not properly accounted for in the analysis could result in the predictions of the injected ECC carried to the break being less than actually occurs. The primary concern is the analytical difficulty in characterizing the countercurrent flow situation in the downcomer region of the vessel. Steam flow at high velocity up the down'omer during blowdown may prevent water from falling to the lower plenum. However, even if $100 \%$ of the ECC injected is assumed to bypass the core and is expclled through the: break, a fault does not occiur for this branch of the tree unless the lower plenum is empty at the end of blowilown and the lbowilown time from 600 p8i to containment pressure is significantly longrer than predicted. For exumple, in lerms of the cladding temperature rise resulting from ECC lypans atad a loigur blowdown tinie, an crror of a factor of two in the exprected blowilown time would add, af anost, $300^{\circ} \mathrm{F}$ to the: cladding temperillure at initiation of reflooding. However, because of the

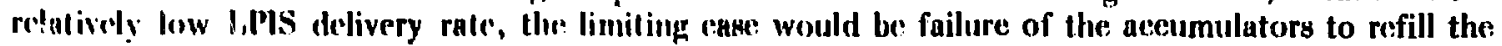
lower plomum. 'I'his siluntion would probubly wecur with 100\% bypuss if the depressurization time; from

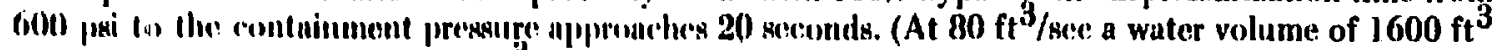
would be lost out of about $2500 \mathrm{ft}^{3}$ total in the three arecumulators.) 
ind increase with burnup. For the higher values, large changes have little ef fect. However, ${ }^{\circ} \mathrm{F}$, the time-temperature response of the cladding starts to be affecled. The authors inderpredict the stored energy by more than $20 \%$ which is the minimum error that would of the tree. The early LOFT tests are expected to provide a basis for establishing error nd showing that the fault is indeed unlikely.

identify assumptions required to make the event chains independent.

\section{THES TO INITIATE REFLOODHG}

l'igure 4, addresses the problem of whether elements of the analysis codes used to atly erroneous that limits rould be exceded beeause core reflooding does not occur as bown heal transfer, prerupture stored energy, and decay power generation celemenss of fted. As would be expected, elements on this braneh include items rolated to whon fic: tie vessel lawer planum could be filled by injection of the inventory in the accumulators. scussed in the following subsections. The inhibit gate is used to emphasize that, unless a $40 \%$ or more) bypasses the core and is expelled through the break during blowdown, the lowdown time are not of particular significance to this fault.

hulator Delivery Rate. For the particular type of plant and accident s, each with a nominal water volume of $850 \mathrm{ft}^{3}$, are assumed available. one on the broken loop, is assumed to discharge into the eontainment. arge rate for the three accumulators is about $80 \mathrm{ft} / \mathrm{sec}$. The predicted ors to fill the lower plenum, downcomer, and core bypass area which is (a total volume of about $1750 \mathrm{ft}^{3}$ ) in slightly more than 20 seconds after The lower plenum would refill up to the bottom of the core in about 12

diet the achual delivery rates if the hydraulic resistances between the y system arr higher than assumed, or if the accumulator gas presiure or ssumed. To be a significant problem on this branch of the tree, the error, I have to result in the predicted delivery rate being more than a factor of eccumulator delivery rate. A reduction of the delivery rate by two from ice about a ten second delay in the time required to fill an empty lower heatup rale, permit the temperature to rise about $200^{\circ} \mathrm{F}$ higher than ly unlikely, a combination of errors involving the prerupture accumulator passing the core to the break during blowdown, and the length of the guch that. rontrary to prediclions, the lower plenum does not fill before d. The time would then be ample for temperature limits to be exceeded :ction system (LPIS) could raise the water level to the core bottom and ery rate of the L.PIS, which is eight to ten times less than the delivery rate ould be inadequate to prevent this fault.

Bypass to the Break During Blowdown. The possibility exists that ounted for in the analysis could result in the predictions of the injected seing less than actually occurs. The primary coneern is the analytical he countercurrent flow situation in the downcomer region of the vessel. p the downcomer during blowdown may prevent water from falling to the if 100\% of the FCC injected is assumed to bypass the core and is expelled ses not occur for this branch of the tree unless the lower plenum is cmply the blowdown time from 600 psi to containment pressure is significantly example, in trrms of the eladding temperature rise resulting from ECC ' $n$ time, an crror of a factor of two in the expected blowdown time would ladding tenperature at initiation of reflooding. However, hecause of the rate, the limiling case would be failure of the accumulators to refill the would probably ureser wilh $100 \%$ bypass if the depressurization time from

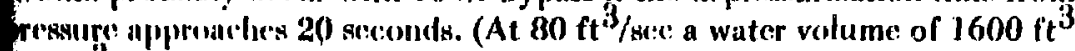

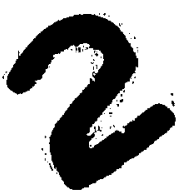
$.00 \mathrm{ft}^{3}$ Lotal in the three accumulators.) 
Analysis underpredicts time to initiote reflooding

Analysis underpredicts ECC byposs to break during blowdown

System effects delay core reflooding
Analysis overpiedic occumulator delivery rate

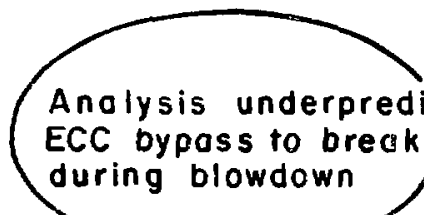

Y
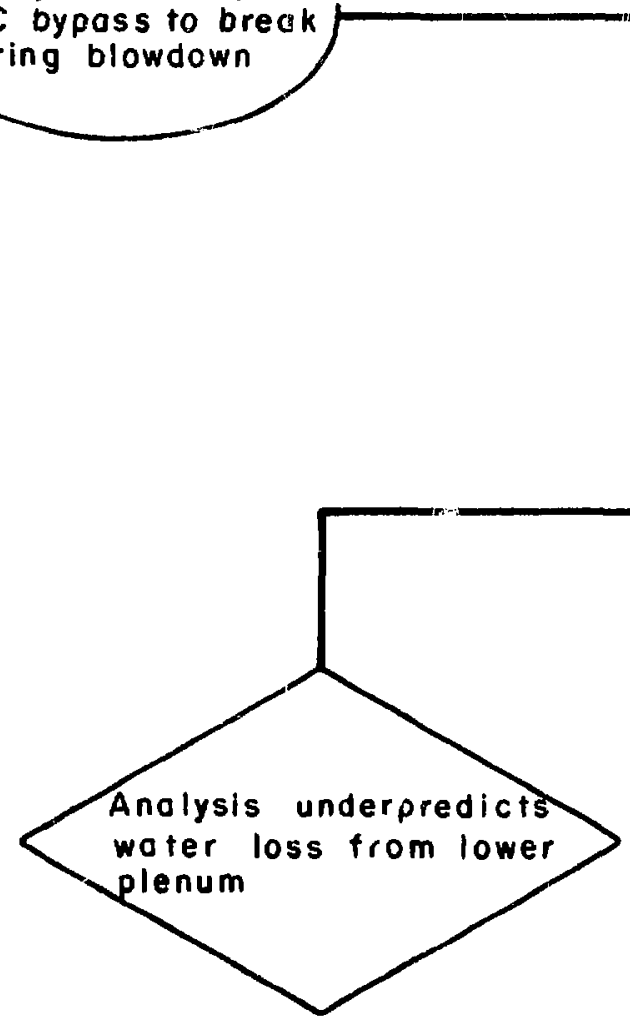

Analysis underpredicts blowdown time

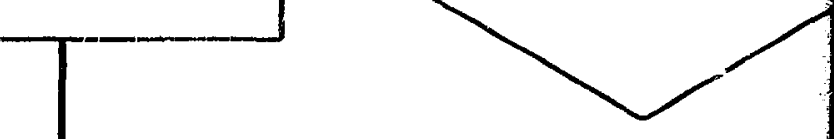




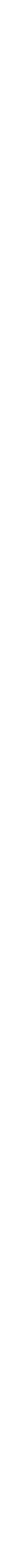


Although hydraulic mechanisms resulting in $\mathrm{ECC}$ bypass of the core during blowdown are not precisely modeled in the analysis code, indications are that the calculated effectiveness of the ECC will be suitably conservative if $100 \%$ by pass is assumed to occur until the time in the blowdown process at which calculated momentum fluxes up the downcomer are below the value at which countercurrent flooding cor elations 2 predict downflow of water.

(3) Analysis Limberpredicls Bli.wdown Time. lior this branell of the trec the preceding discussion indicaleal that the artual bowdown time from Gol) pes to the eontainmen! pressure would have fo be at least a

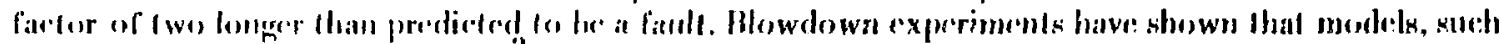

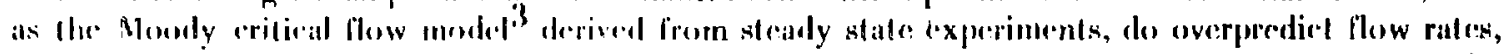

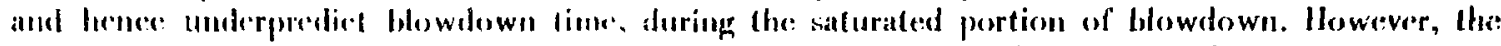

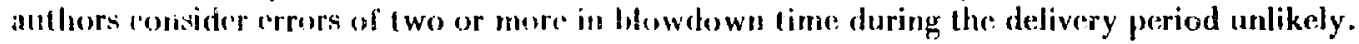

(4) Analysis Underpredicts Water Loss from the Lower Plenum. If a system is slowly depressurized from operating conditions to containment pressure, about $40 \%$ of the fluid in the lower plenum ilashes to steam and is lost from the lower plenum. A few percent also flashes due to heat transfer from surrounding wiriaces. To empty the lower plenum at the end of blowdown, the other $60 \%$ of the fluid would have to be removed by entrainment. For large breaks accompanied by rapid depressurization rates, high-velocity reverse flow could occur in the core and empty the lower plenum.

Present analysis models, limited to a onc-dimensional representation of the fluid flow, cannot directly accomnodate entrainment in the lower plenum. For large breaks, homogeneous one-dimensional representation of the lower plenum docs predict that the lower plenum is nearly empty at the end of blowdown. Thus, in general, the predic:led rosults are not expected to deviate significantly from worst anse conditions. $\Lambda$ significant crror could possibly be introduced in the predictions of the water remaining in the lower plenum if the moklels are manipulated to accommodate modeling difficulties regarding the delivery phase of the aceident. For example, if the model is changed so that the accumulators discharge: cold water into the lower plenum during blowdown and then in effect remove some assuriced fraction of the ECC at the end of blowdown to aecount for ECC by pass, the results may show significantly inore water remaining in the lower plenum than would actually occur.

\section{Branch 3--ANALYSIS UNDERPREDICTS CORE TEMPEKATURE AT TIME OF REFLOODING INITIATION}

This branch of the tres addresses the problem of betermining whether errore can occur in the calculated time-t behavior of the eladding such that the predicted temperalures are sufficiently lower than the actual temperatures there in the temperature limits being exceeded even if reflooding effectiveness is as predicted.

The tree developed for this branch is shown in Figure 5. It has essentially the same elements as those on Branc (Figures 3 and 4), but the acecptable error in maximum temperature rise during blowdown is several hundreel degred branch of the tree, based on predicted energy removal rates during reflooding, takes into account the fact thal $t$ curnaround docs not occur at the initiation of roflowing for certain designs and points ont that a temperature exis execeded at the time of core reffooding, will result in violation of the upper limit. The faulte on this brancle of essuntially the same an for the two brunches previonely discussed under the fault "analysis in orror-linite violated pr refleoding". If developed, the dianond on the right "unalysis overpredicts energy removal rates during blowdown or un stored energy" would include all elemente of Branch ! of Figure 3 . The inputs on the left side of Branch 3 are the san" shown on Bramrh 2. If the predicted temperalures at the start of core reflooding are about $1600^{\circ} \mathrm{F}$, the magnit acecptable crrors discussed for inputs on Branches I and 2 would have to be reduced by aboul $40 \%$ to be appropriat this Iranch. In lle indliors opinion, faulte on Bramelh 1 concerned wilh errors in predicted blowdown heat transfer (probally! resulting from crrors in calculated core flow aroas and fluid slate) and in prerupture stored energy would be thin the oiluer crrors on these I wo lorunches.

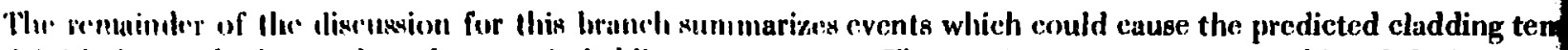

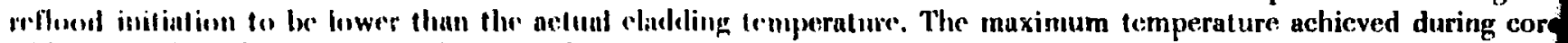

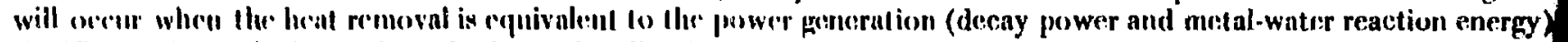
kignificant line will hase dapned after refloodling is initialed belore overull maximum temporatures are reached (40)

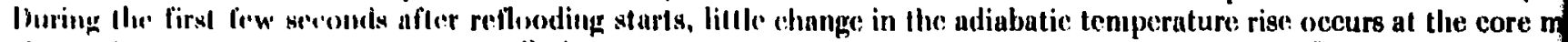
ubowe. A rate of lemperalure rise of $20^{\circ} \mathrm{F} / \mathrm{sec}$ alone prolentially permits lemperatures to rise by $100^{\circ} \mathrm{F}$. After the first waler levels in the corr are sulficiently high to provide sufficient steam generation to entrain fluid and carry it? clevations. 'Typically, the energy removal rates at this time are still less than the power generation rate because syc 
ting in ECC bypass of the core during blowdown are not precisely yations are that the calculated eficctiveness of the ECr will be s is assumed to occur until the time in the blowdown $p$ seess at up the downcomer are below the value at which counteicurrent ow of water.

ime. For this loranch of the Irec the preceding discussion indicated 600() psi to the containment pressure: would have to loe at heast a Ior a fiult. Blowdown experimenls have shown that modrels, such friverl from stealy state experiments, do overpediel flow rates, time, during the saturated portion of blowdown. However, the: a in blowowown time during tho delivery period unlikely.

tom the Lower Plenum. If a system is slowly depressurized from pressure, about $40 \%$ of the fluid in the lower plenum flashes to plenum. A few percent also flashes due to heat transfer from lower plenum at the end of blowdown, the other $60 \%$ of the fluid inment. For large breaks accompanied by rapid depressurization occur in the core and empty the lower plenum.

onc-dimensional representation of the fluid flow, cannot directly ower plenum. For large breaks, homogencous one-dimensional does predict that the lower plenum is nearly empty at the end of redicled results are not expected to deviate significantly from rror could possibly be introduced in the predictions of the water e models are manipulated to accommodate modeling difficulties accident. For example, if the model is changed so that the to the: lower plenum during blowdown and then in effect remove the enci of blowdown to account for ECC bypass, the results may ting in the lower plenum than would actually occur.

\section{TEMPERATURE AT TIME OF REFLOODING INITIATION}

lem of determining whether errors can occur in the calculated time-temperature temperatures are sufficiently lower than the actual temperatures thereby resulting eflooding effectivenesis is as predicted.

In in Figure 5. It has essentially the eame clements as those on Branches I and 2 aximum temperature rise during bluwdown is scveral hundred degrees less. This removal rates during reflooding, takes into aceount the fant that leniperalure reflooding for certuin designa and points out that a temperature exists which, it esult in violation of the upper limit. The faults on this brancli of the trece are evicusly discussed under the fault "analysis in error-linits violated prior to core tht "analysis overprediets energy removal rates during blowdown or underpredicts - anch 1 of Figure 3. The inputs on the left sides of Branch 3 are the same as inputs tures at the start of core reflooding are about $1600^{\circ} \mathrm{F}$, the magnitude of the ses I asol 2 would have to be reduced by about $40 \%$ to be appropriate errors for ranch I concerned with errors in predicted blowdown heat transfer coefficients (c. flow art:as and fluid state) and in prerupture stored energy would be more likely

rumel summarizes events which could cause the predicted cladding temperalure at idding temperature. The maximum temperature achicved during core reflooding the: power parceration (decay power and metal-water reaction energy). In general, has is initiated before overull inaximum temperatures are reached (40 to 80 sec). Is, little change in the adiabatic temperature rise occurs at the core midplane and ne polentially perınits lemperatures to rise by $100^{\circ} \mathrm{F}$. After the first few seconds, provide sufficient steam generation to entrain fluid and carry it to the high t this tine are still less than the power generation rate because system effects, 


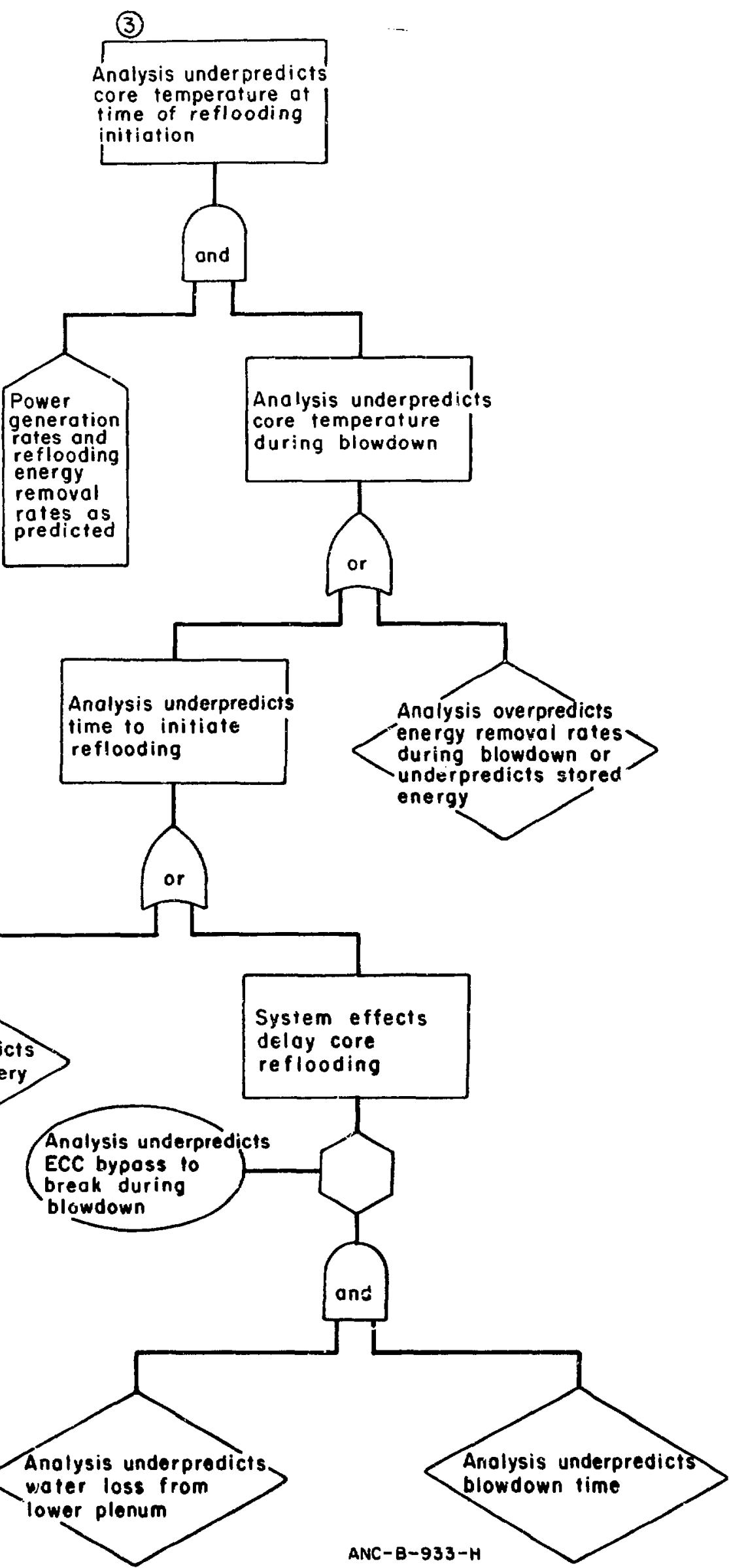

Fig. 5 Treo develupment for antalysis underpredicts core temperature at time of reflooding initiation. 
rehaled lo sicam binding, limit reflooding rates. Temperalures conlinue: to rise but at a kower rate. $\Lambda$ s time passes in the core inewes to higher elevations, the conergy remowal rales inerease, decay power levels decrease, and tempe occors.

The relationship of the maximum calculated cladding tomperature to this temperalure at refloonl inít reflooting ratis is sioww in Sivtion IJ] which presenls a summary of sensitivity study results. Jor the particuid for this eximple tree, the study show: that, if attual temperatures are about $2000^{\circ} \mathrm{F}$ at the start of core reflood rates are as predicted, temperature limits will he exceeded. 'This branch of the tree points out the need for. precision in the analysis of system brhavior during blowdown than would be required to show that faults on the (hranches 1 and 2) will nol occur.

\section{Branch 4-ANALYSIS UNDERPAEDICTS POWER GENERATION DURING CORE REFLOODING}

Branch 4 ileseribes events which would eause cladding temperature and temperature-time limits to be exc power gentration rales are lower than actual rates. The tree developed fo: this branch is shown in Figure 6.

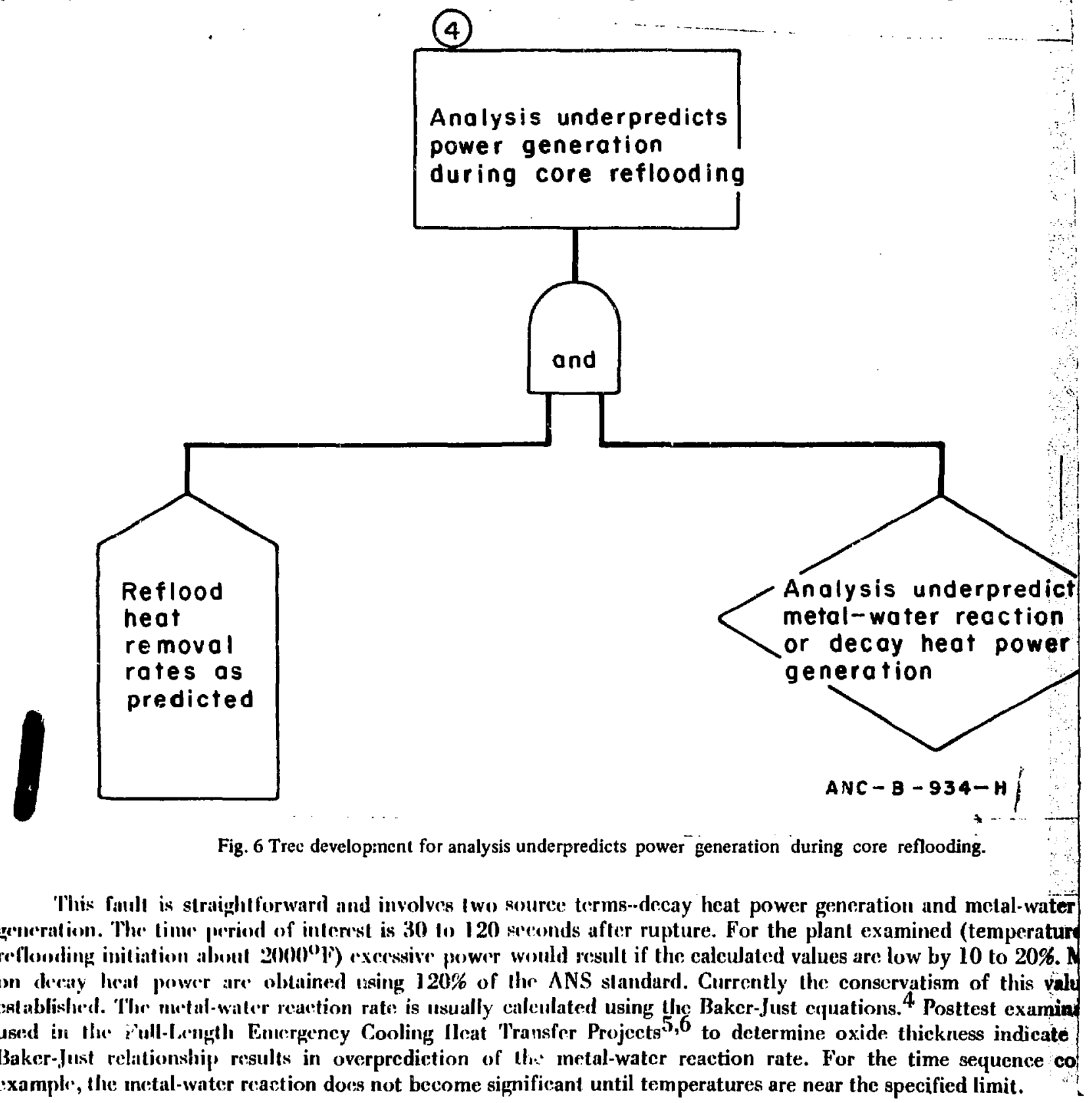

In the anthors" opinion, predietions based of a power generation rate of 1.2 times the $\Lambda$ NS standard and a multi in the lBuker-Just ancrgy calculation will prevent a funlt on Braunh 4. 
calculated clateling tromperature to the lemperalure at reflood iniliation for varions gich presents a summary of sensitivity sludy results. leor the partieular plant aomsidereol , if achual trmperatures are aboit $2000^{\circ} p$ al the start of core reflooding and reflooding will be excereded. This branch of the trre points out the need for considerable more during blowdown than would be required to show that faults on the previous branclies

\section{POWER GENERATION DURING CORE REFLOODING}

ald cause cladding temperature and temperature-time limits to be exceeded if predieted il rates. The trec developed for thi $i$ branch is shown in Figure 6.

Analysis underpredicts power generation during core reflooding

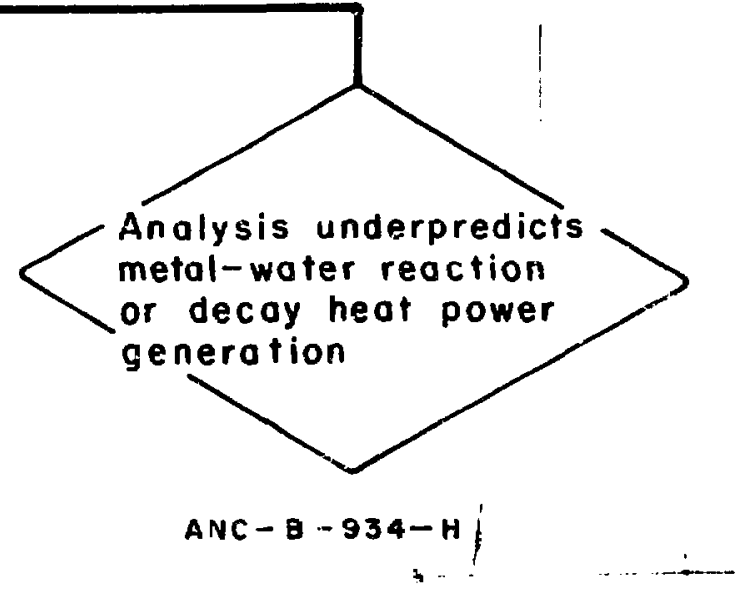

for analysis underpredicts power generation during core reflooding.

blves two source terms--decay heat power gencration and metal-water reaction energy 30 to 120 seconds alfer rupture. For the plant examined (temperatures at the time of No power would result if the calculated values are low by 10 to $20 \%$. Most calculations $120 \%$ of the ANS sindard. Currently the conservatism of this value lias not loeen 3 usually calculated using the Baker-Just equations. 4 Posttest examination of bundles ing Ileat Transfer Projects ${ }^{5,6}$ to determine oxide thickness indicate that use of the fiction of the metal-water reaction rate. For the time sequence considered in this become significant until temperatures are near the specified limit. 
This branch of the tree considers those crrors that could exist in the predicted energy removal rates such limits are cxceceled unexpectedly during core refloweling. The fault tree for Branch 5 is shown in Figure 7. Figure development of the troc for "analysis overprediets reflooding flow rate".

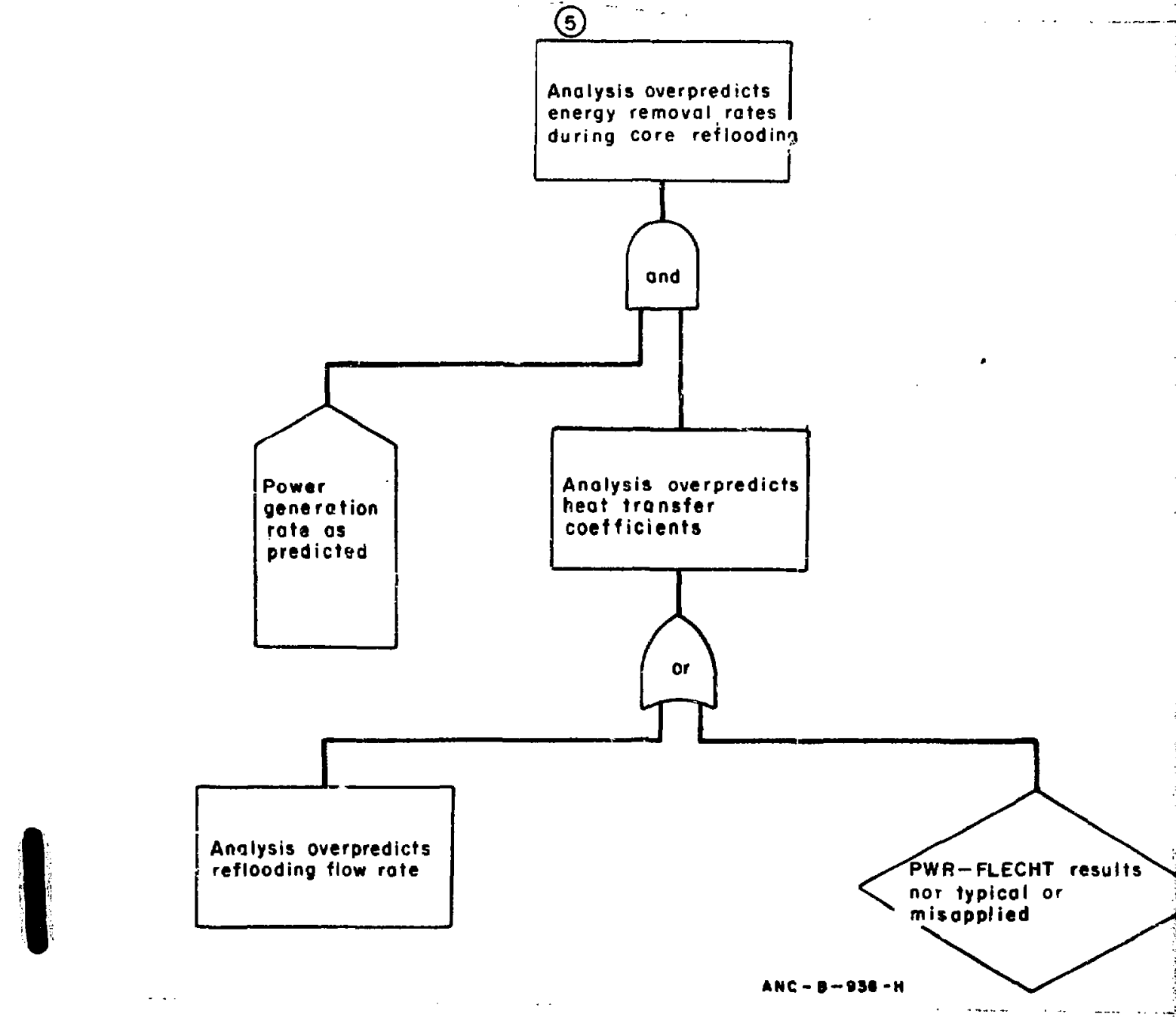

Fig. 7 Tree development for analysis overpredicts energy removal rates during core reflooding.

The time period of interest for this fault is the same as noted in the discussion on power generation; th seconds. The actual duration is, of course, a fisnction of plant design, temperature levels, and ECC system pe' potenlial sources of errors in analysis, which are considered in the upper section of the tree, include methods fo water level in the dowicomer (the driving head for reflooding), the major elements of the steam binding $P$ resislance to steam flow from the corc to the break), and the potential for errors in the experimental base use reflooding heat transfer coufficients.

1 general understanding of the present method used to derive the predieted heat transfer coefficients is use the devefopment of the. tree below the slatement "analysis overpredicts heat transfer coefficients". In safety prodicled values are simply heat transfer confficionls derived from PWR-FLECHT tests. 5 The applicable PWR-FLE a disign problem are selected by identifying the appropriate systeni and core conditions existing at the time refloo will sprevilie consideration given to containment pressure, eladding temperature, water temperature in the low

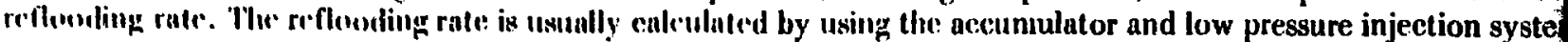
miss frantion of the flow inlo llon botlom of the cors: whish is assumed to exit the bundle (derived from FLEC

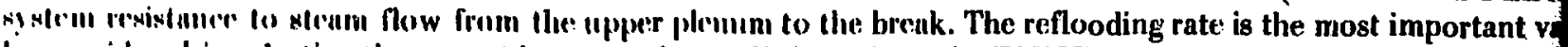

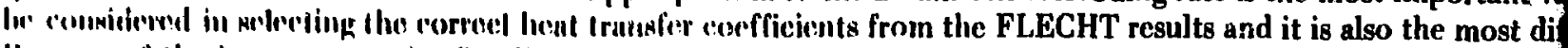

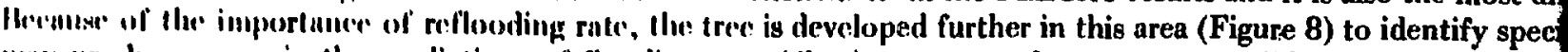
muy prodice crrors in the prediutions of floodiug rale. All other sources of errors are consolidated in the discussi

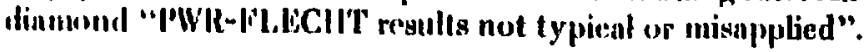




\section{ERGY REMOVAL RATES DURING REFLOODING}

e errors that could exist in the predicted energy removal rates such that temperature re reflooding. The fault tree for Branch 5 is shown in Figure 7 . Figure 8 shows further zdicts reflooding flow rate".

(5)

Analysis overpredicts

energy removal rates

during core reflooding

Analysis overpredicts

heat transfer

coefficients

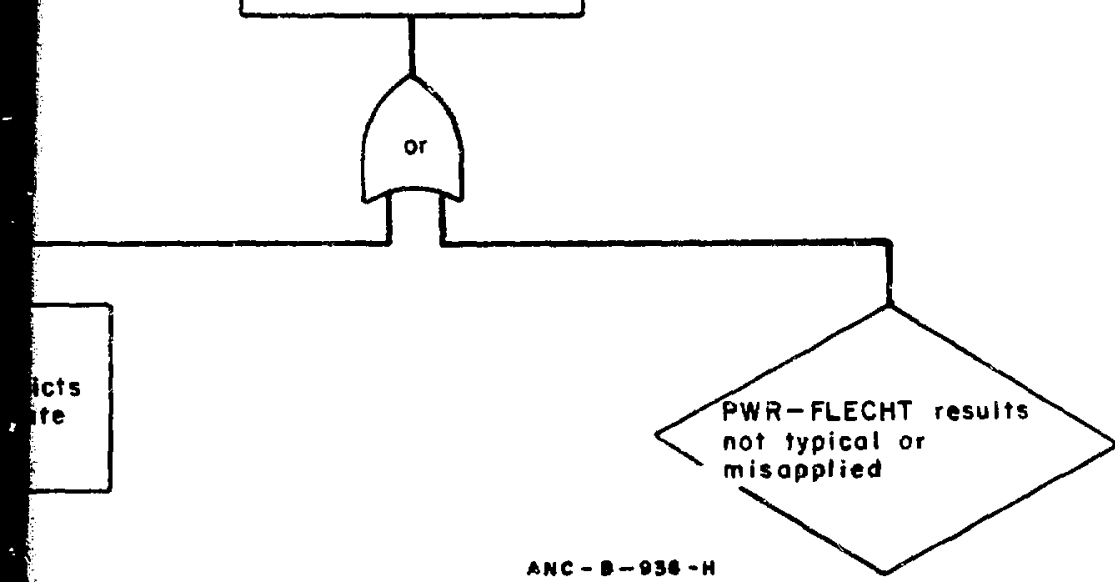

ment for analysis overpredicts energy removal rates during core reflooding.

is fault is the same as noted in the discussion on powen genera: on; that is, 30 to 120 e, a function of plant design, temperature levels, and ECC aystem performance. The iich are considered in the upper section of the tree, include methods for evaluating the ing head for reflooding), the major elements of the stcam binding problem (system to the break), and the potential for errors in the experimental basc used to obtain the

went method used to derive the predicted heat transfer coefficients is useful in following statement "analysis overpredicts heat transfer coefficients". In safety calculations, the corfficients derived from PWR.FLECHT tests. 5 The applicable PWR-FLECHT results for

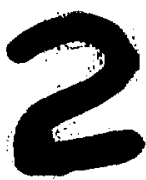
Ing the appropriate system and core conditions existing at thr time reflooding is initiated, tainmeni preseure, cladding temperature, water temperature in the lower plenum, and blly culvolined by using the accumulator and low pressure injection system delivery rates, In of llue cors: whith is assumed to exit the bundle (derived from FLECHT results), and (upper plomun to the brenk. The reflooding rate is the most important variable that must trunsfir verfficients from the FLECHT results and it is also the most difficult to obtain. snte, the tree is developed further in this area (Figure 8) to identify specific events which flooding rate. All other sources of errors are consoildated in the discussion related to the "al or misnpplied". 


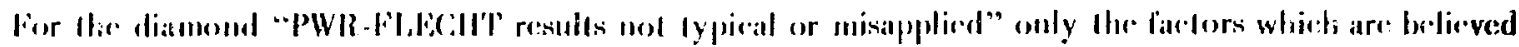

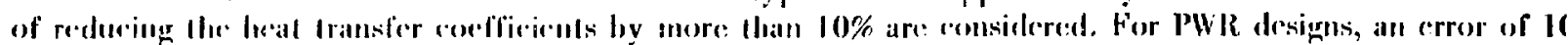

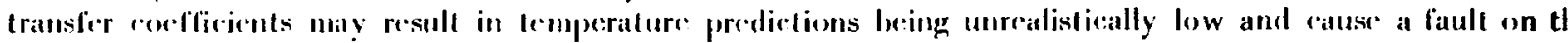
temperatures at reflooding iniliation are above: $1600^{\circ} \mathrm{F}$. With regard lo heat transfer confficients oblained from lests nol being lypieal, the following I wo areas of uncertainty wot:ld have been incentified if the tree had ber more leverl:

(1) Now maldistribulion resulting from blockage or radial ecmperalure gradients in a large core produce heat transicer coefficients lower than observed for PWR-FIECCIT'

(2) Iheal transler coefficionts for zirealoy-elad rods al low reflooding rates may be lower than heat trar cocflicients olutainced from PW'R-Fl,ECIIT' tests which used stainless sterel-clad rods.

As noted in Seetion IV both areas are being considered for investigation by additional experimental work.

lu larms of misapplication of the Fl, QCUT' results, a 10\% overprediction in the value of the heat

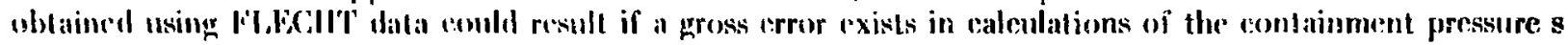
presisures are 15 an 20 pri higher than the an:(nal pressures. Also for low reflooding, if the FIJC(IIT hest trans used, the predieled condfiesent may be high by more: than 10\%.

\section{Analysis Overpredicts Reflooding Vlow Rate}

The subbranch of the tree for low core reflooding rates was shown in Figure 8. In calculations of thil the pressure Jrop from the core inlet to the core outlet plus the pressure drop from the core outlet back to equated to the licad of water in the downcomer. A $17 \%$ error in reflooding rate calculations would be necess error in heat transfer coefficients. The three diamonds on the right relate to the supply of water to the downce factor in the reflooding rate calculations. In order for a fault to occur, the predicted downcomer water heigh about $40 \%$ higher than the actual height.

Further development of the tree bolow the diamond "aecumulators empty before predicted" would inclu' errors shown on Brameh 2. The magnitude of the aceeptalie difference between predieted and actual behavior : considerably less on this branch than on Branch 2. On this branch, the predicted belıavior for a pr *dicted ace rate of about $80 \mathrm{ft}^{3} / \mathrm{sec}$ is for the lower plenum downeomer and dewneomer bypass region (a total volume of be filled before the accumulators are emptied. Since the total volume of the accumulators is only about 2250 by pass of the core during hlowlown and a blowdown time 4 or 5 seconds longer than predicled conld cause this

Onee the downcomer is full, for H.CC entrainment to affict the water height in the downeomer, mor incoming I,PLS flow weuld have to be lost, The polenlial lour an analysis error resulti.ng in an overpredietion unlikely because in actıalily two systems are available and the predictions are based on lice assumption that one

The event in the diamond of Figure 8, "analysis underpredicts mass flow rate from vessel", would uccu core outlet flow to the core inlet flow is about $17 \%$ higher than observed in the FLECIIT lests. At present, cald used for reflooding evaluations do not treat the mass and cnergy transfer process rigorously. Instead, time-de data are used in the ealculations to account for the fraction of the core inlet mass flow which exits the vessel. vendors indicate that the inass fraction out of the vessel as derived from the FLECIT experiments is higher than reactor cores because of the small size of the PWR.FLECIIT lundle and the fact that a hot seclion of the PWR

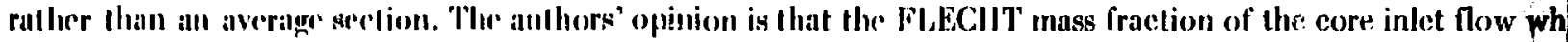

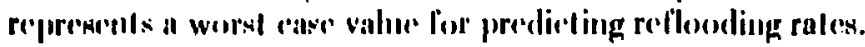

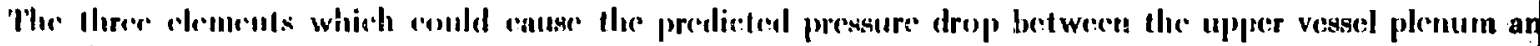

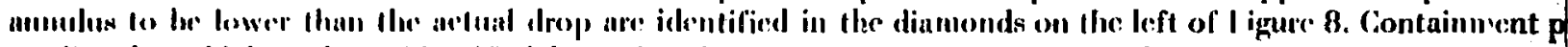

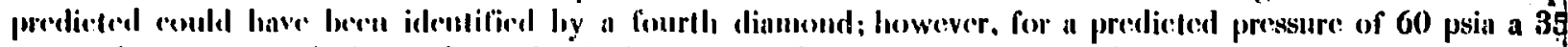

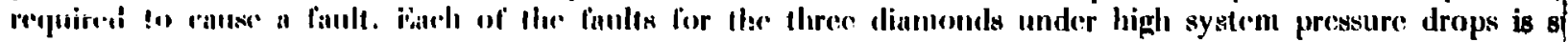

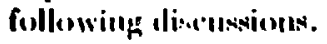

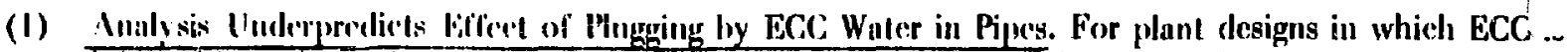
injectod into llie piping, the actual pressure drops will be complex functions of inor entum and energy exehumges between the liCC and the steam flowing in the lines. Two-phase pressure drops of real significame. in lerms of core reflooding rates are most likely to occur during accumulator injection 


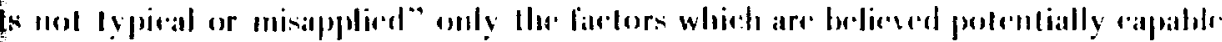

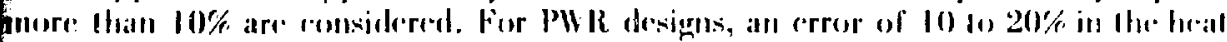

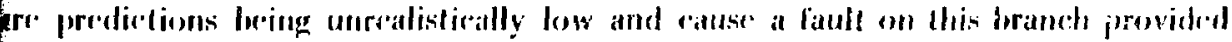

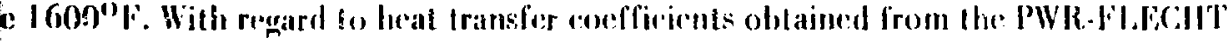
as of uncertainty would have been identified if the tree had been developed to one

fom blonkange or radial temperature gradients in a larese core may

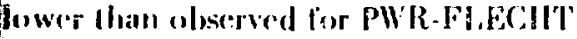

aloy -elici rods at fow reflooding rates may be lower than heat transfer IdGCIIT losks which used stainlets steel-rlad rods.

nsidereni for investigation by additional experimental work.

ECLIT results, a $10 \%$ overprediction in the value of the heat transfer cocfficient a gross caror exists in calculations of the containment pressues such that calcolated

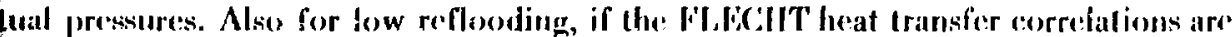
more than $10 \%$.

1

reflooding rates was shown in Figure 8 . In calculations of the core reflooding rate, eore outlet plus the pressure drop from the core outlet back to the downcomer is mer. A $17 \%$ error in reflooding rate calculations would be necessary to cause a $10 \%$ diamonds on the right relate to the supply of water to the downeomer which is a key order for a fault to occur, the predicled downcomer water height would have to be

the diamond "accumuiat ors emply hefore predieted" would include all the potential the acecptable, difference between predicted and antual behavior would, however, be: heh 2. On this branch, the predicted behavior for a predicked accumulator discharge fum downeomer and downcomer bypass rejion (a total volume of ahout $1750 \mathrm{ft}^{3}$ ) $\mathrm{io}$ 1. Sinec the total volume of the accumulators is only about $2250 \mathrm{ft}^{3}$, complete EC.C. wown time 4 or 5 seconds Jonger than predicted could cause this faull.

fentrainment to affect the water height in the downeomer, more than $25 \%$ of the The potential for an analysis crror resulting in an overpredietion of LPIS delivery is vailable: and the predictions are based on the assumption that one systern fails.

"analysis underyedicts mass flow rate from vessel", woald oceur if the ratio of the ut $17 \%$ higher than observed in the FLECIIT tests. At present, caiculational methods the mass and energy transfier process rigorously. Instead, time-dependent FLECHIT or the fraction of the core inlet mass flow which exils the vesscl. At present, several the vessel as derived from the FLECl1T experiments is higher than expected in larger PWR.FLECIT hendle and the fact that a hot section of the PWR core was simulated pinion is that the l.ECII' mass fraction of the core inlet flow which exits the verisel loceding ralos.s.

the pereliefed pressure drop betweren the upper vessef plenum and the downeomer inlentified in the dinnsends on the ieft of rigure 8. Containment pressure lower than burth dianond: hewever, ior a predlieted pressure of 60 psia a $35 \%$ error would be: lor the Ihree diamonds under high system pressure drops is summarized in the

Phugging by EC.C. Water in Pijes. For plant designs in which ECC is I prexsure : Irops will be complex functions of momentum and energy the steam flowing in the lines. Two-phase pressure drops of real corting ates are most likely to occur during accumulator injection 
when ECC flow rates are high. The authors' opinion is that if the angle of the ECC injection line is such that the ECC momentum is directed down the pipe the plugging problem would be less than for an ECC. line with a 90 degrce angle to the inlet piping. Although perhaps not significant, the assumption that one of the two LPIS systems fails to operate, which is customarily assumed in safety analysis, would not be conservative in caleulating core reflooding rates provided the downeomer is filled by the accumulator.

(2) Analysis Underpredices Encrgy or Mass Transfir from Steam Generator Secondary System to Primary

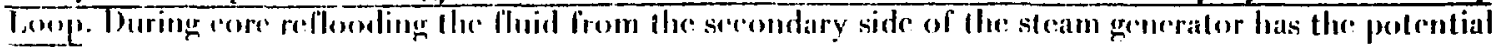

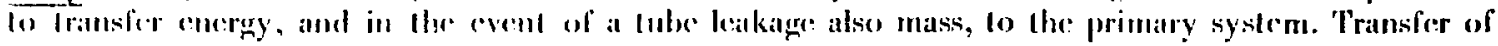

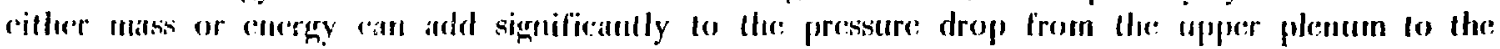
downeomer antulus. Vuless lon: secondary side has depressurized before reflooding is initiated, signifieant errors in refloseling rales would occur if conergy transfer processeses are not properly taken inte areoumt. Current predietions, which are hased on the secondary side of the steam generator being al normal operaling temperatures at reflooding initialion, are considered to account for all cenergy Irinsiler processes. If only a feu tubes leak, mass tansfer processes can also significantly add to the error in the ealculated reflooding rates. To provide a $17 \%$ reduction in reflooding rates (at $1.5 \mathrm{in} . / \mathrm{sec}$ ), a tube break arca of about $0.003 \mathrm{ft}^{2}$ would be required. Present predictions are based on the assumption that none of the tuloes fail.

(3) Analysis Underpredicts Pump Resistance. During the reflooding phase of the accident the pump is subjected to a superheated stcan flow at a rate which considerably exceeds the pump capacity. In this situation the pump is simply a resistance. It is, however, the component with the highest resistance in the operating loop and would cause unacceptable reflooding rates if actual values of pump resistance excered predicted vilues by about $50 \%$. Potential sources of croors in evaluating pump resistance include:

(1) Error in calculating pump speed

(2) Application of an inappropriate pump characteristic curve

(3) Compressibilily effects not taken into account.

Current licensing criteria require the assumption of a locked rotor resistance for the pump when ECC perfurmance is being evaluated. This assumption provides a resistance about twice as high as would be: obtaincd on the basis of the predicted pump speed.

\section{SUMMARY OF FAULT 'TREE APPLICATION}

The following discussion summarizes the example trec developed for a PWR and shows how the faul: tree mi to a BWR.

\section{Example Fault Tree for PWR's}

Figure 9 shows a composite of the tree developed in this section. Because of space limilations the louses whice? state asstamptions and none of the boxes which were included for explanatory notes have been removed. The tree record of the logic: processers used to determinc systematically the sources of errors in current predietive analysis $n$

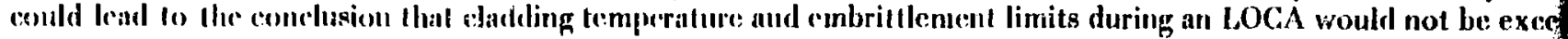

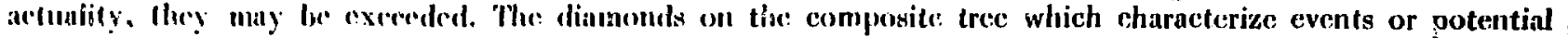
cousidered to loc signifieanl in sprecifying ECC design requirsunents have been enclosed by double lines.

The: double: lines should not loc considered as an indication that present ECC system designs are inadequate; $t$ intended lo highlight variables or items within the analysis which exhibit relatively high influence. For the particul considered in this "xample, finlts on branches I and 2, "analysis in error--limits violated prior to core reflooding", (o) be unlikely and are not enclosed by double lines. Faults on Branches 1 and 2, involving blowdown heat trans mergy Ne nlao shown on Brameh 3. (1) Branch 3 acceptable eirors in the two variables are considerably less thas faulis on Branch I. For this renson, factors contributing to core reflooding being dolayed in time are not enclosed 1

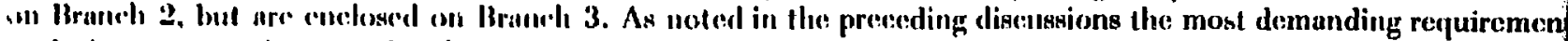
minlysis crrors on inpuls relited lo core refloseding deluyed in time would loe identified by development of the

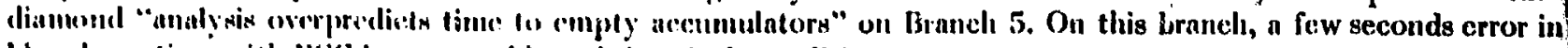

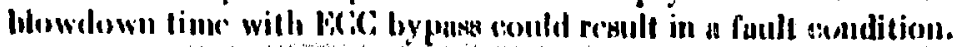


ppinion is that if the angle of the FCC: injection line is such the pipe the plugging problen would be less than for an piping. Although perhaps not significant, the assumption operate, which is customarily assumed in safely analysis, e reflooding rates provided the downeomer is filled by the

Isfer from Steam Generator Secondary System to Primary flic: scenondary side of the steam grencralor has the peotential nube loakage also mass, to the primary system. 'Transfer of y to the pressure drop from the upper plenum to the y side: has depressurized before refloceding is initiatcel. oceur if encrgy transfer provesssess are not properly taken - based on the secondary side of the steam generator beingr bding initiation, are considered to account for all energy mass tansfer processes can also signitiicantly add to the error e a $17 \%$ reduction in reflooding rates (at $1.5 \mathrm{in} . / \mathrm{sec}$ ), a tulse uired. Present predictions are based on the assumption that

During the reflooding phase of the accident the pump is rate which considerably execeds the pump capacity. In this is, however, the component with the highest resistance in ptable reflooding rates if actual values of pump resistance. folential sources of errors in evaluating pump resistance:

pump characteristic: curve

into account.

"ption of a locked rotor resistance for lle pump when ECC ption provides a resistance about twice as high as would be: speed.

tree developed for a PWR and shows how the fault tree might be applicel

in this section. Because of space limitalions the houses which were: used to neluded for explanatory notes have been removed. The tree is primarily a atically the sources of errors in current predictive analysis me:thods which and conbrittlement lienits during an $1,0 \mathrm{C} A$ would not be execeded when, in he composile Irec which characterize cvents or potential analysis faults uirements have been enclosed by double lines.

Indication that present ECC system designs are inadequate; they are simply ysis which exhibit relatively high influence. For the particular plant design "analysis in error--limits violated prior to core reflooding", are considered Tau'ts on Branches 1 and 2, involving blowdown heat transfer and stored ptable errors in the two variables are considerably less than for the same ay to core reffooding bcing delayed in time are not enclosed by double lines in the preceding dinceussions the most demanding requirement for ininionum anyed in time would be identified by development of the tree below the tors" un Branch 5. On tlais branch, a fiw seconds error in the calculated mdition. 


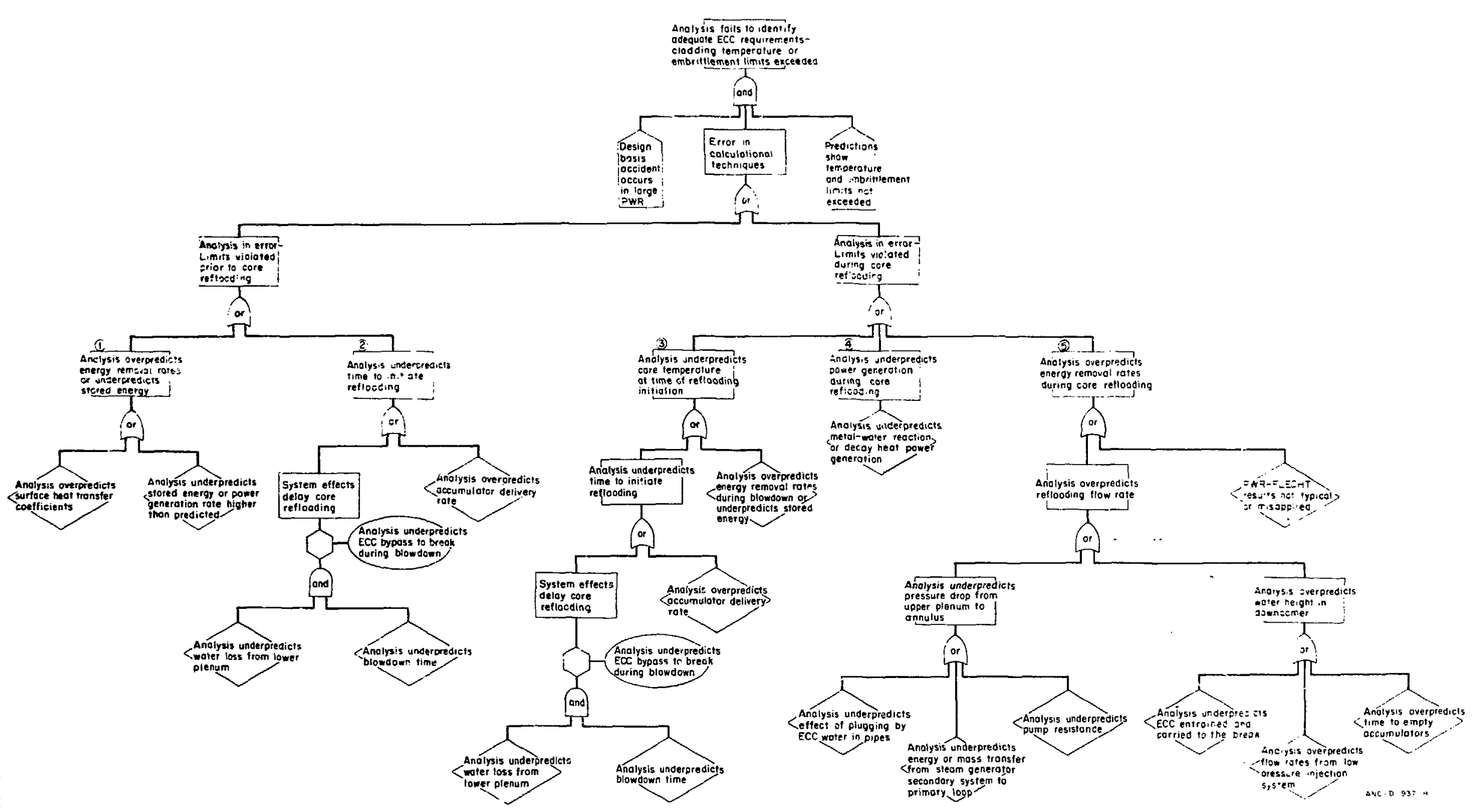

Fig. 9 Summary fault tree for analysis of PWR design basis actident. 
On the composite faull tres all of Branch 4 has been reduced to a single double-lined diamond "analysi metal-water reaction or decay leat power generation". The double line has been added because power generation I correlation with maximum temperature and time-at-temperature when heat transfer coefficients are small.

On Branch 5, which identifics events that can reduce cnergy removal rates during reflooding, five of the eigl enclosed in double lines. As discussed in the preceeding text, the PWR-FLECHT results are among the key facto reflooding heat transfer rates and must loe carefully used in evaluating ECC performante. Another important overprediction of the lime for the accumulators to empty such that in reality the low pressure injection system : downeomer. Beeanse of the relatively small system pressure drops involved, all three of the diamonds under th underpredicts pressure drop from upjer plenum to anuulus" have been enclosed in double lines.

\section{Diseussion of' Factors Affecting Selection of BWR-HCCS Design Requirements Using Example "Tree"}

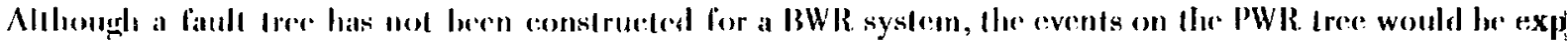
in similar form on the BWR Iree. Since the BWR system uses core sprity and reflooding serfuerned in lime, the th

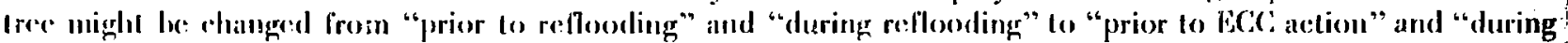
this approach were taken, Branch I of the trec could remain cssentially lloc same but the lop would have "analygi temperaiture--limit execeded prior Io predicted tinu to spray initiation". The top of Branth 2 might loc chang underpredicts time: Lo spray initiation". "The clements on Branch 2 would also have to be changed fo refleet the fol analysis fiults:

(1) Analysis underprediets spray system delivery

(2) System effects delay spray initiation

(a) Analysis underprediets blowdown time:

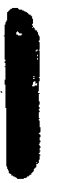

(b) Analysis overpredicts core spray rate--core stcam flow distorts spray distribution until the end of: blowdown.

The top of Branc! 3 would probably he changed to "analysis underpredicts tomperature at spray initialion" and th" inchede fanles similin to those of" Branelese I and 2. Branch 4 would remain the same with the execption that "dur would be chlanged to "during liCC: acelion".

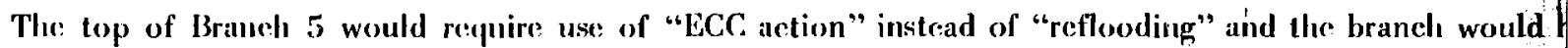
below the Lop "or" gale on "BWR-F'L.ECHT results" much like the one for "PWR-FLECHT tesults". The remainde Branch 5 bolow the first "or" galc: would change considerably. Perhips the event "analysis underpredicts core $\mathrm{r}$ would be replaced with "analysis miderpredicts core spray rate to hot bundles" and the tree would be developed fue event. Another event would also be drfined for input to lle top "or" gate and this event would be "analysis under initiate core refluodiug". In a BWR, a stcam binding problem is not expeeted, but for high power density plants core reflooding could be eritical because the spray system only slows the rate of the cladding temperature rise. The the time to start core reflooding is shown by the performance studies in the next section.

\section{PERFORMANCE OF LIGHT.WATER REACTOR ECC SYSTEMS}

'This serelion presents an evaluation of the sensitivily of the performanee of ECC systems for BWR's and $P$ range of possible condilions axisting at the timo ECC: action is initialed. Calculated cladding temporalures and emb

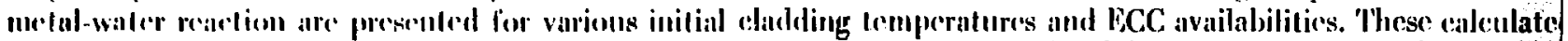

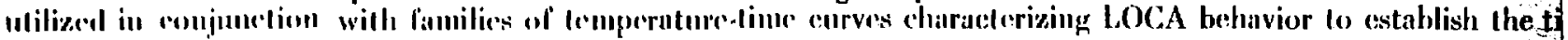

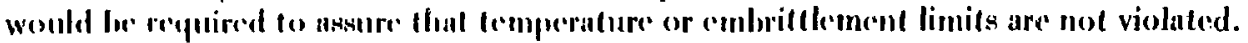

Fing a Pll wilh reflooding as the EC:C action, performance maps are presented which relate the max lemperal ure and cmbrittlement to the lemperature al reflooding initialion for a wide range of nominal core refloo influener of other pintumeters which affect the maximum eladding temperature during ECC action are abo discussiou covers the sensilivily of lemperature and combrittement to initial power, containment backpressur thickness, metal-walce reaclion ratc, and delay in reflooding time. To assist in relating the performance m characterislics that control reflooding rutes in LWR's, calculational results are presented showing reflooding rates for al break in the four-loop plant considered previously in this paper. The sensitivity of the reflooding rate in the reference $p$ to water pluming in thre inlet piping, pump resistance, and depletion of the accumulators before the downeomer is ref shown. 
4 has been reduced to a single double-lined diamond "analysis underpredicts "tion". The doulyc line has been added because power generation has a one-to-one -at-temperature when heat transfer cocfficients are small.

can reduce energy removal rates during reflooding, five of the right diamonds are: eceeding text, the PWR-FLECHT results are among the key f'actors in calculated efully used in evaluating ECC performance. Another important fault would be: to empty such that in reality the low pressure injection system had to refill the tem pressure drops involved, all three of the diamonds under the box "analysis to anmulus" have beren enclosed in double lines.

\section{-LCCS Design Requirements Using Example "Tree"}

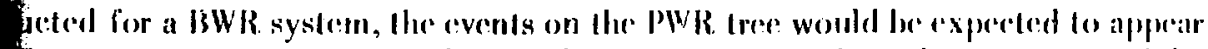
R system uses core spray and reflooding sequeneed in lime, the lopecenents of the"

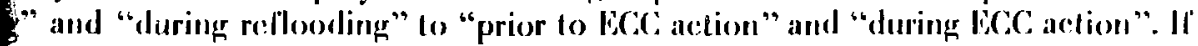
could remain essentially ihe same but the lop would have "analysis underprediels time to spray initiation". The lop of Branch 2 might be changed to "analysis pents on Branch 2 would also have to be changed to reflece the following types of

Helivery

wn time

y rate--core steam flow distorts spray distribution until the end of

to "analysis underprediets temperature at spray initiation" and the branch would 2. Branch 4 would remain the same with the exception that "during reflooding"

f "ECC action" instead of "reflooding" and the branch would have a diamond ts" much like the one for "PWR-FLECHT' results". The remainder of the tree for ge considerably. Perhaps the event "analysis underpredicts core reflooding rale"" gre spray rate to lot bundles" and the tree would be developed further under this" aput to the top "or" gate and this event would be "analysis underprediets time to ting problem is nol expected, but for high power density plants the time to start y system only slows the rate of the cladding temperature rise. The importance of erformance studies in the next section.

\section{E OF LIGHT-WATER REACTOR ECC SYSTEMS}

gensilivity of the performanee of ECC systems for BWR's and PWR's to a wide: SCC, action is initiated. Calculated claddling temperatures and embrittlement from tial cladding temueralures and BCC.C availabilities. 'Tliese calculated results can be ure-lime curves characterizing I,OCA behtovior to establish the time ECAC action nlsrittlement limils are not violated.

petion, performance maps are presented which relate the maximum cladding fo at reflooding initialion for a wide range of nominal core reflooding rates. The maximum eladdling temperature during ECC action are also discussed. The and embrittement to initial power, containment backpressure, initial oxide in reflooding time. To assist in relating the performance maps to system ' 's, calculational results are presented showing reflooding rates for a inlet piping in this paper. The sensitivity of the reflooding rate in the reference plant design nce, and depletion of the accumulators before the downcomer is refilled is also 


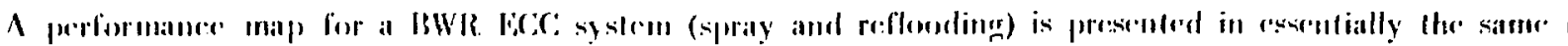

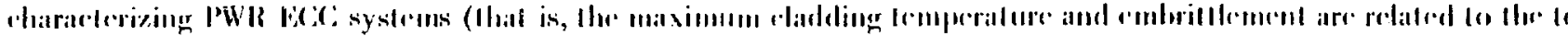

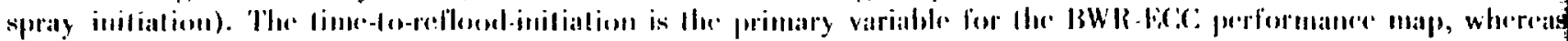

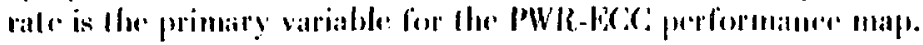

Cladding cmbrilt!emenl values are also slown on the PWR and BWR performanes maps in terms of percent en

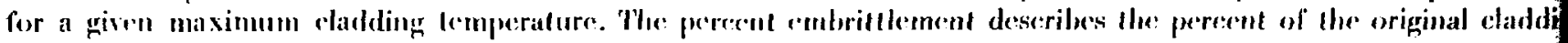

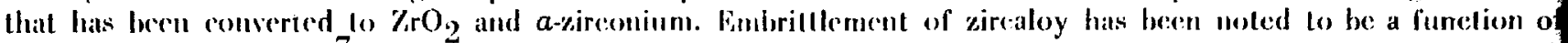
content of the material. ${ }^{7}$ Oxyeren, in addition lo forming a britte layer of Z,r(th on the outer storface of the elad temperalures diffuses thromgh the oxide layer to form a layer of brittle oxygen-induced a-zireonium. Photomicrogra reactor zircaloy samples's were used to establish thall a lactor of approximately 2.2 is regured to correlate $\mathrm{ZrO}_{2}$ thi total thiekness of $\mathrm{ZrO}_{2}+$ a-zirconimm. Thus, the prereenl cmbrittlement is calculated direclly from the predicted $\mathrm{Zr}$, by assuming oxidation occurs on only the cutside surface of the cladding. A gencrally accepted value for the $p$ cladding that can be oxiclized and still survive rod quenching is 17 to $18 \%$. 8 ,9 These percentages correspond to an e: of approxinately $4.0 \%(2.2 \times 18 \%)$ of the original dadding thiekness. At $40 \%$ embrittlement, a radial load of 80 pound sample: wats foutud to cause birille, failure?

\section{PRESSURIZEV WATER REACTOR LCCS PERFORMA NCE}

T'le" selection process for PWR-FCC system design requirements discussed in previous sections involved use of temperalure-time curves porl raying system loc A response: for the eomplete range of break sizes and localions in conj" system respense dala after lic.C action had been laken. This section presents calculational methods and resuits of sludy using these melloods to provide: PWR systent respense after reflooding is initiated. The results are expected to the overall process of seleeting ECC system design requirements. The results presented can be used to evaluate the is the errors in items identified on the lault tree in the: previous section as having significant effect on reflooding en rates.

\section{Source of Heat Transfer Coefficients for Study}

As discusted in previous sections, evaluation of PWR system performance during core reflooding involves applic transfer coefficients derived from the PWR-FI.FCHT test program. 5 The PWR-FLECHT program provided steady sta dat:a for a wide range of reactor conditions. Isocal cladding surface temperatures were measured in PWR-FLECHT te heat transfer coeffieienls based on the saturation temperature as the reference temperature were calculated. The Pr experimental program included reflooding experiments on 12-ft clectrically heated rods (both 49. and 100-rod bundle 'T'he rod diameter and spaceing were typieal of those of a PWR. $\Lambda$ filament down the center of each rod was wound chopped-eosime axial power profile. 'The filanent was surromeled by boron nitride which served as an electrical insul? results used in the following diseussion were obtaincel from stainless sicel-elad rods.

Fignure 10 is a typical example of heat transfer coeffieionts obtained at five axial locations along a PWR-FIBCIIT test. 'The data on which these coctlicients are based were obtained during an experiment which temperature of $2000^{\circ} \mathrm{F}$ and which employed a reflooding rate of $1 \mathrm{in} / \mathrm{sec}$. Even though the heat transfer significantly lower at elevations higher than the 6-ft elevation (midplane), the maximum temperatures usually oc midplane because of the cosine power distribution. Heat transfęr coefficients for the midplante were used in the study

\section{Application of Heat Transfer Data to Obtain Nuclear Rod Performance Using the HEAT-1 Code}

The IIEAT'- 1 computer code ${ }^{10}$ was used to solve the transient encrgy conduction equation for one axial $l$ midplanc) on a simulated nuclear rod. The code: represents the rod with 33 radial nodes from flue rod center line

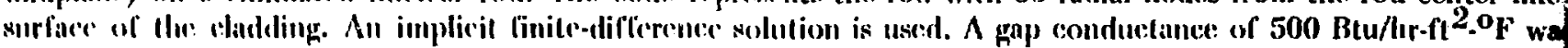

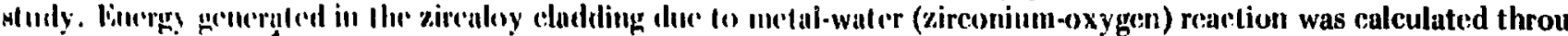

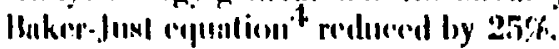

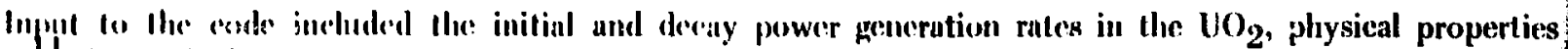

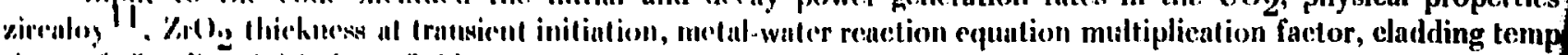

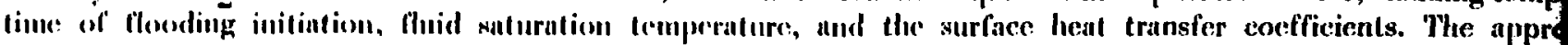
comditions at llw time core refloceding was intiated were oblitined by setting the rod materials temperatures 200 .

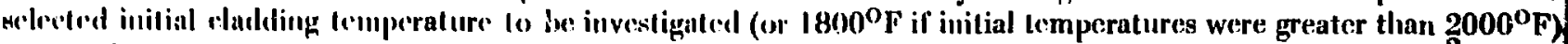

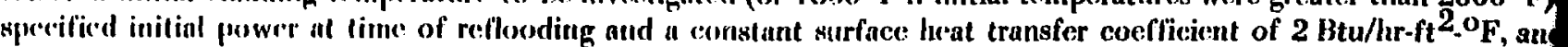
calculation of cladding surtace tomperature to continue. Wlien the calculated cladding temperature reached the selec temperature: vuluc, the programnied power decay was applied and the appropriate heat transfer coefficie PWR-lidifC.11T bundle midplane were substituted for the constant value. 


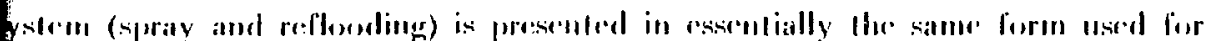

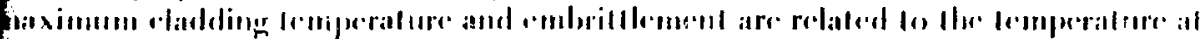

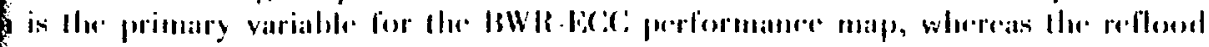
thrormallure mily.

Hown on Ihe PWR and BWR prerformanec: malps in terms of pereant embriltement

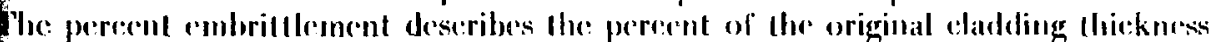
nium. Finbritllement of zircaloy hats been noted to be a function of the oxygren to forming a britle layer of $\mathrm{ZrO} \mathrm{O}_{2}$ on the ouler surface of the cladding, at high to form a layer of brittle oxygen-indueed a-xirconium. Pholomicrographs laken of sh that a lactor of approximately 2.2 is requared to correlate $\mathrm{ZrO}_{2}$ thickness to the the percent embrittement is calculated directly from the predicted $\mathrm{ZrO}_{2}$ thickness utside surface of the cladding. A generally aceepted value for the perechtage of rod quenching is 17 to $18 \% .8,9$ These percentages correspond to an embritllement ail cladding thickness. At $40 \%$ embritlement, a radial load of 80 pounds per inch of

\section{RFORMANCE}

a'm dresign requirements discussed in previous sections involved ust: of a farrily of CA response for the complete range of break sizes and locations in conjunction wilh een laken. This secelion presents caleulational methods and results of a sensitivity stem response after reflooding is initiated. The results are expected to be helptul in sign requirements. The results presented can be used to evaluate the import ance of e in the previous section as having significant effect on reflooding energy removal

fion of PWR system performance during core reflooding involves application of heat FCII'T test program. 5 The PWR-FLECHT program provided steady state reflooding ocal cladding surface temperatures were measured in PWR-Fl.ECHT lests, and loceal fion L'mperature as the reference temperature were calculated. The PWR-l'LECII'l' erimenls on 12-ft clectrically heated rods (holh 49- and 100-rod hundles were usied). those of a PWR. A filament down the center of each rod was wound to produce a ent was surrounded by boron nitrides which served as an relectrical insulalor. The lest taincel from stainless stcel-celad rods.

Eat transfor cocfficients obtained al five axial locations along a rod during a se coeflicients are based were obtuined during an experiment which started al a ed a reflooding rate of 1 in./sec. Even though the heat transfer coefficient is the 6.ft elevation (midplane), the maximum temperatures usually occurred at the fon. Heat transfer coefficients for the midplane were used in the study discussed.

\section{uclear Rod Performance Using the HEAT.I Code}

d to solve the transient energy conduction equation for onc axial location (core. ond: represents the rod with 33 radial uodes from the rod center line to the ouler foremee solution is used. $\Lambda$ gap eonduntance of $500 \mathrm{Btu} / \mathrm{hr}-\mathrm{ft}^{2}{ }^{\circ} \mathrm{F}$ was used in the g dur Io merlal-wailer (virconium-oxygen) reartion was calculated through use of the:

and deraly power generation rates in the $U()_{2}$, physical properties of $\mathrm{U}_{2}$ and in, imetal-waler reat:tion ecpuation multiplieation factor, eladding lemperalure at the (1:onperature, and the surfiace heal transfer coefficients. The appropriale initial iiliated were obticimed by setting the rod enaterials temperatures $200^{\circ}$ lo bolow the stigaled (or $1800^{\circ} \mathrm{F}$ il initial temperatures were greater than $2000^{\circ} \mathrm{F}$ ), applying the id a constant surface heat transfer coeflicient of $2 \mathrm{Btu} / \mathrm{hr}-\mathrm{ft}^{2}{ }^{\circ} \mathrm{F}$, and allowing the continue. Wlicen the calculated cladding temperature reached the selected reflooding decay was applied and the appropriate heat transfer coefficients from the d for the constant value. 


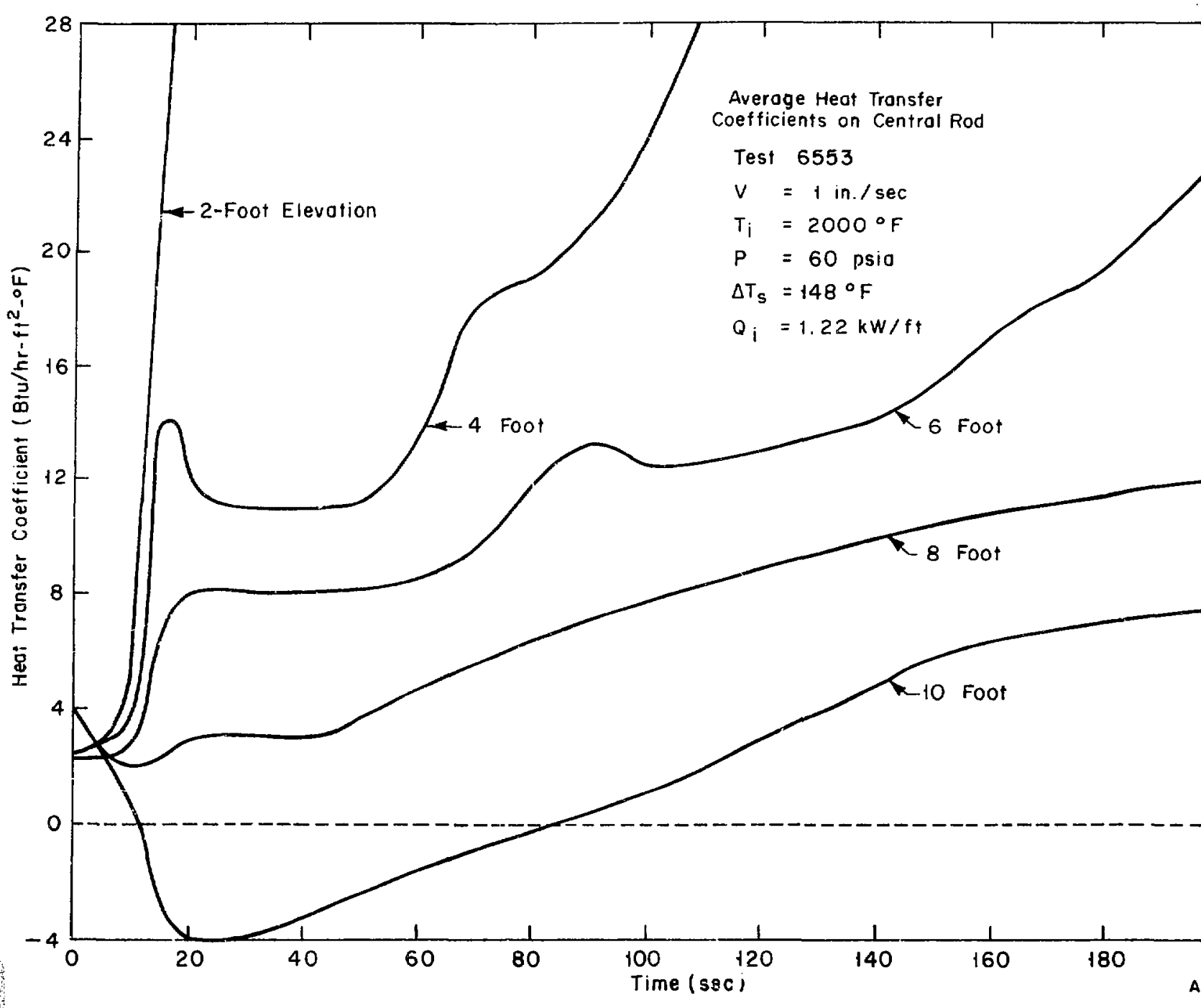

Fig. 10 PWR-FLECHT nominal heat transfer coefficients.

The code output was the radial temperature distribution aeross the rod and the pereent of eladding embrit functions of time after initiation of seflooding.

lipure 11 presents examples of the results calculated by the: JEAT-] code. These particular examples of the cladding temperature-time behaviur and the percent embrittlement of the cladding at various times after refiouding of caleulations based on an initial chateling temperalure at lime of reflooding of $2000^{\circ} \mathrm{F}$ and various core flooding examples, the elacleling is subjected Io ligh temperatures for a relatively long time.

To proside a summary of rors: performance during refiooding, a map, shown in Figure 12, was constructe maximun cladding temperature to the temperature al rellooding initiation. Each point on the map is taken

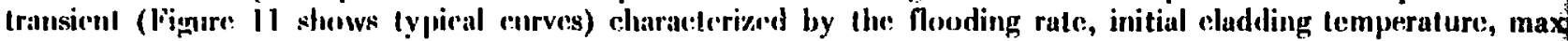

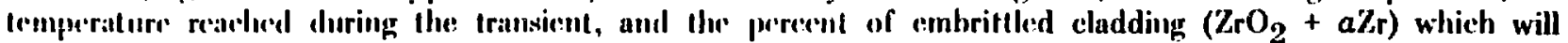
coobdown. 'Iloc initial reladeling temperature reffers lo llue clalding temporalure at the core hot spot at the time the lo the reaclor is filled and liooding of the eore begins.

Kristits shown on lhe niap are for a peak initial power of $1.22 \mathrm{~kW} / \mathrm{ft}$ at reflood initiation, the PWR-FLECh

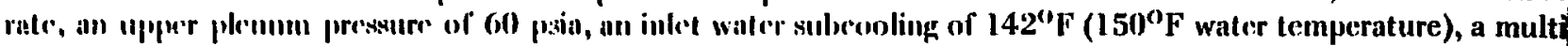

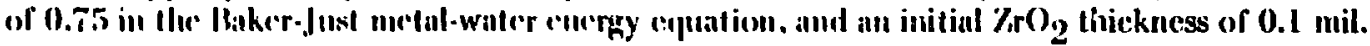

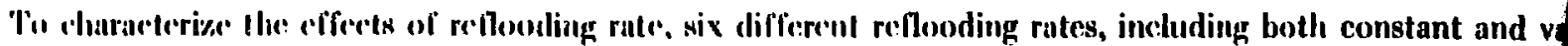

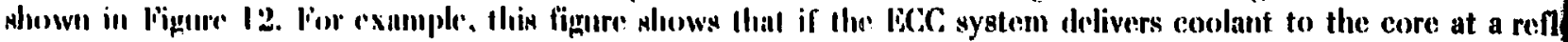

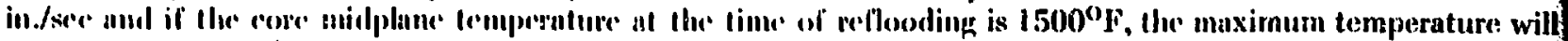

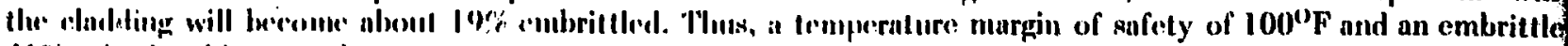

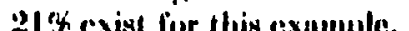




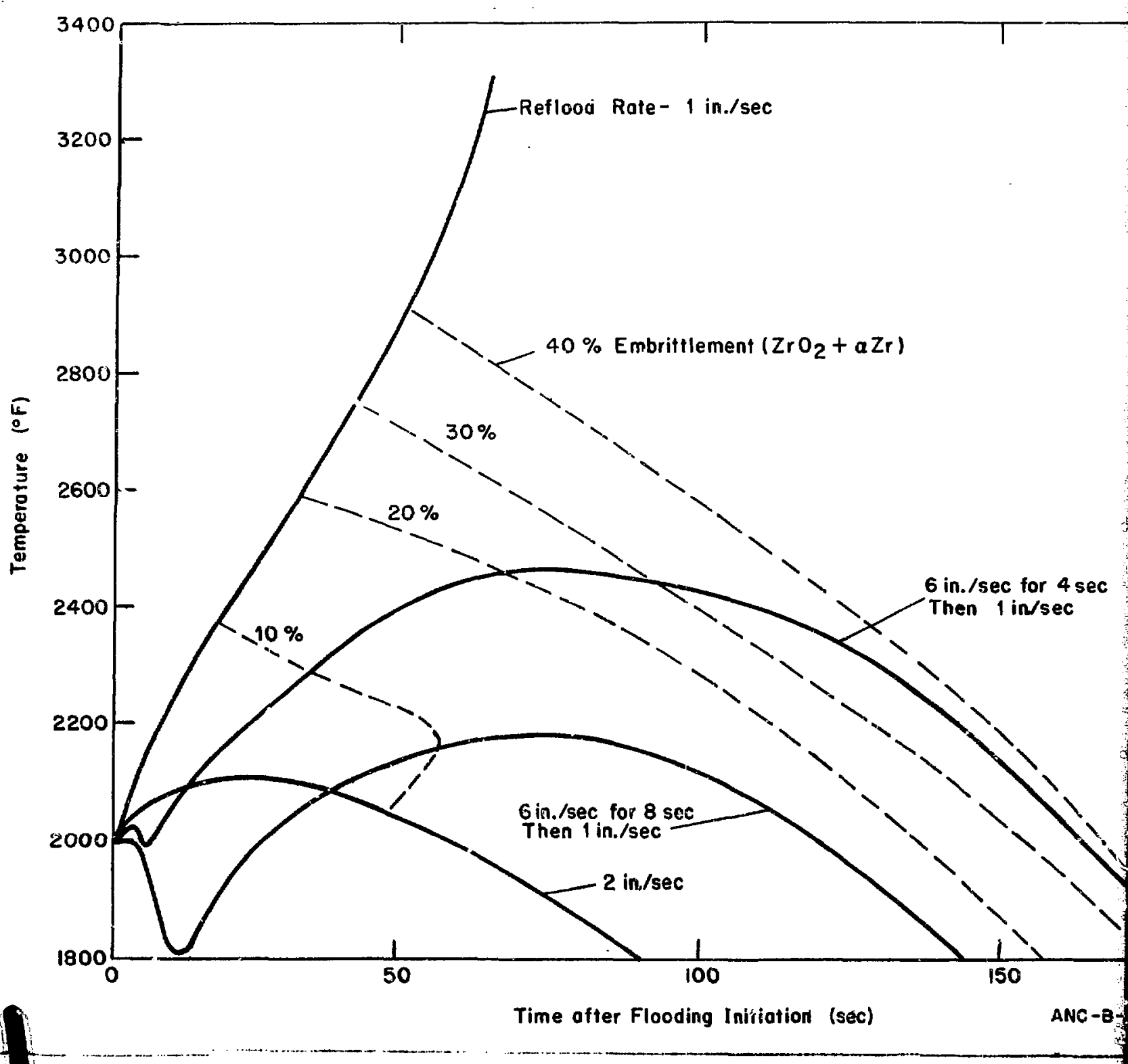

Fig. 11 Calculated PWR temperature-time behavior for various flooding rates.

An interesting characteristic revealed by Figure 12 is that the calculated lines of constant percent 0 approximately horizontal. For the type of temperature transients investigated, embrittlenient was almost wholly maximum temperature. Although the time at temperature is important, variations in the time to reach the maxi were generally overshadowed by the dependence of the exponential iemperature rise on the reaction rate coeffici

As an aid in estimating the effect of several other parameters, results from other sensitivity studies are pre This table shows the percent change in the cladding temperature rise and embrittlement for two points on Figure are for 2000 and $1600^{\circ} \mathrm{F}$ initial temperatures for a flooding rate of $5 \mathrm{in} . / \mathrm{sec}$ for 4 seconds followed by a floodin By utilizing the information in Table I and the curves of Figure 12, new performance maps could be constructed.

The: largent rhunges occur in the $2000^{\circ} \mathrm{F}$ coslumn besenuse the metul-water reaction energy is more

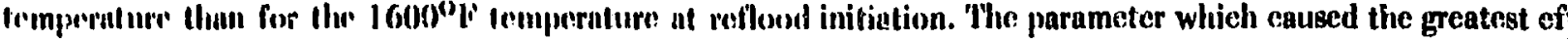
power. Nest, in the urdar of impostance, are: (a) metal-water reaclion energy multiplying factor; (b) the time a brgins; and (o) $\mathrm{ZrO} \mathrm{O}_{2}$ thickness.

Anolher important parameter alfeeting the relationship between the temperature at the time of reflooding maximum! fempernlure for " given reflonding rate is contuinnent pressure. The containment pressure affects th well as the hent transler for a apeeific flooding rate. As an example of this effect, if the corc pressure is 25 psia 


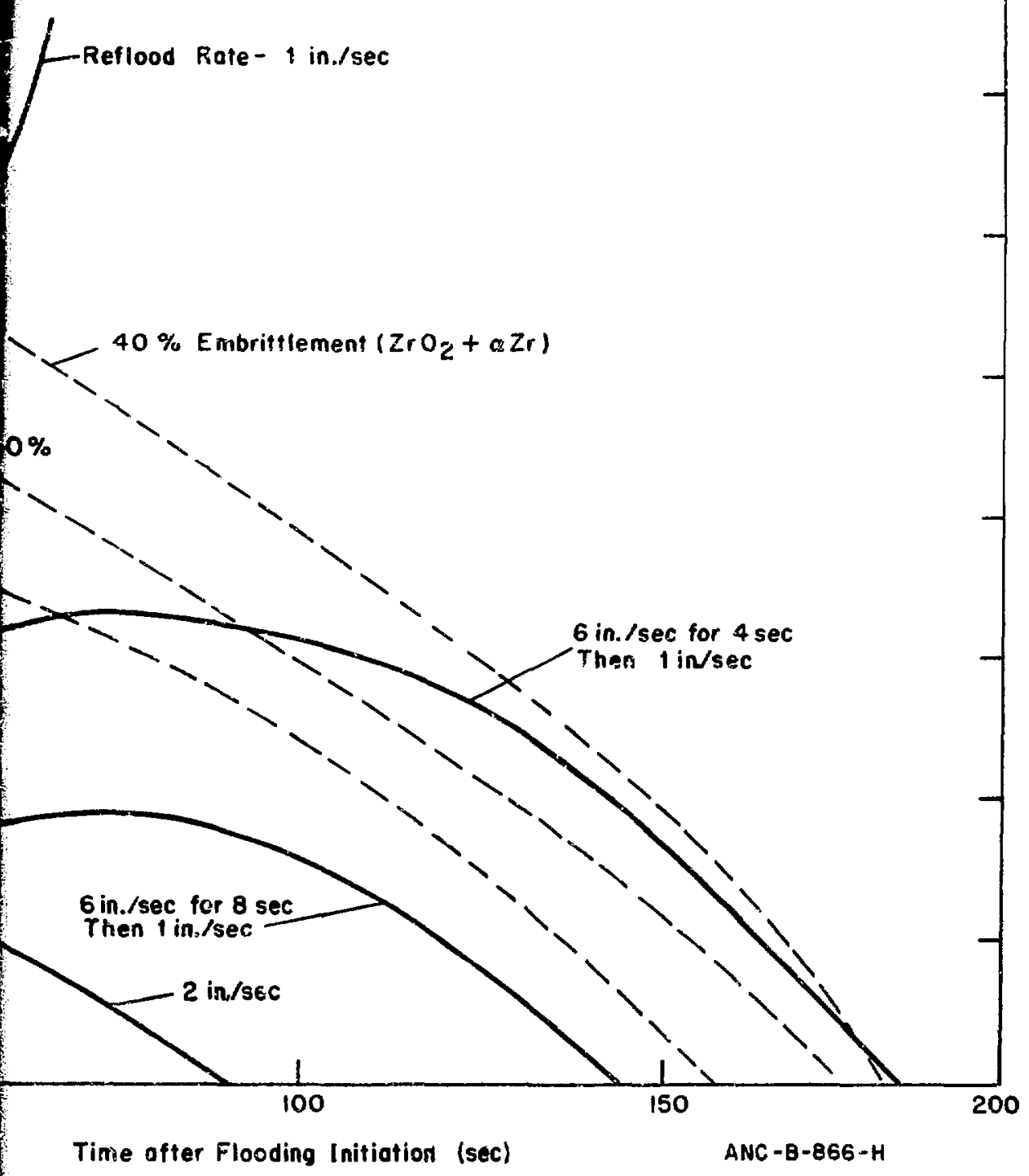

d PWR temperature-time behavior for various flooding rates.

by Figure 12 is that the calculated lines of constant percent embrittement are -mperature transients investigated, embrittlement was almost wholly a function of the t temperature is important, variations in the time to reach the maximum temperature ice of the exponential temperature rise on the reaction rate coefficient.

veral other parameters, results from other sensitivity studies are presented in Table I. ladding temperature rise and embrittlement for two points on Figure 12 . These points tor a flooding rate of $6 \mathrm{in} . / \mathrm{sec}$ for 4 seconds followed by a flooding rate of $1 \mathrm{in} . / \mathrm{sec}$. e curves of Figure 12, new performance maps could be constructed.

$60^{\circ} \mathrm{F}$ column berause the metal-water reaction energy is more significant at this ot: al rollowd initiution. 'The prasameter which caused the greatest effect was the initial ( $($ ) metal-water reaction energy multiplying factor; (b) the time at which reilooding

the relutionship between the temperature at the time of reflooding initiation and the rate is containment pressure. The containment pressure affecte the flooding rate as igg rate. As an cxample of this effeet, if the core pressure is $25 \mathrm{ps}$ a - -stead of 60 psia 


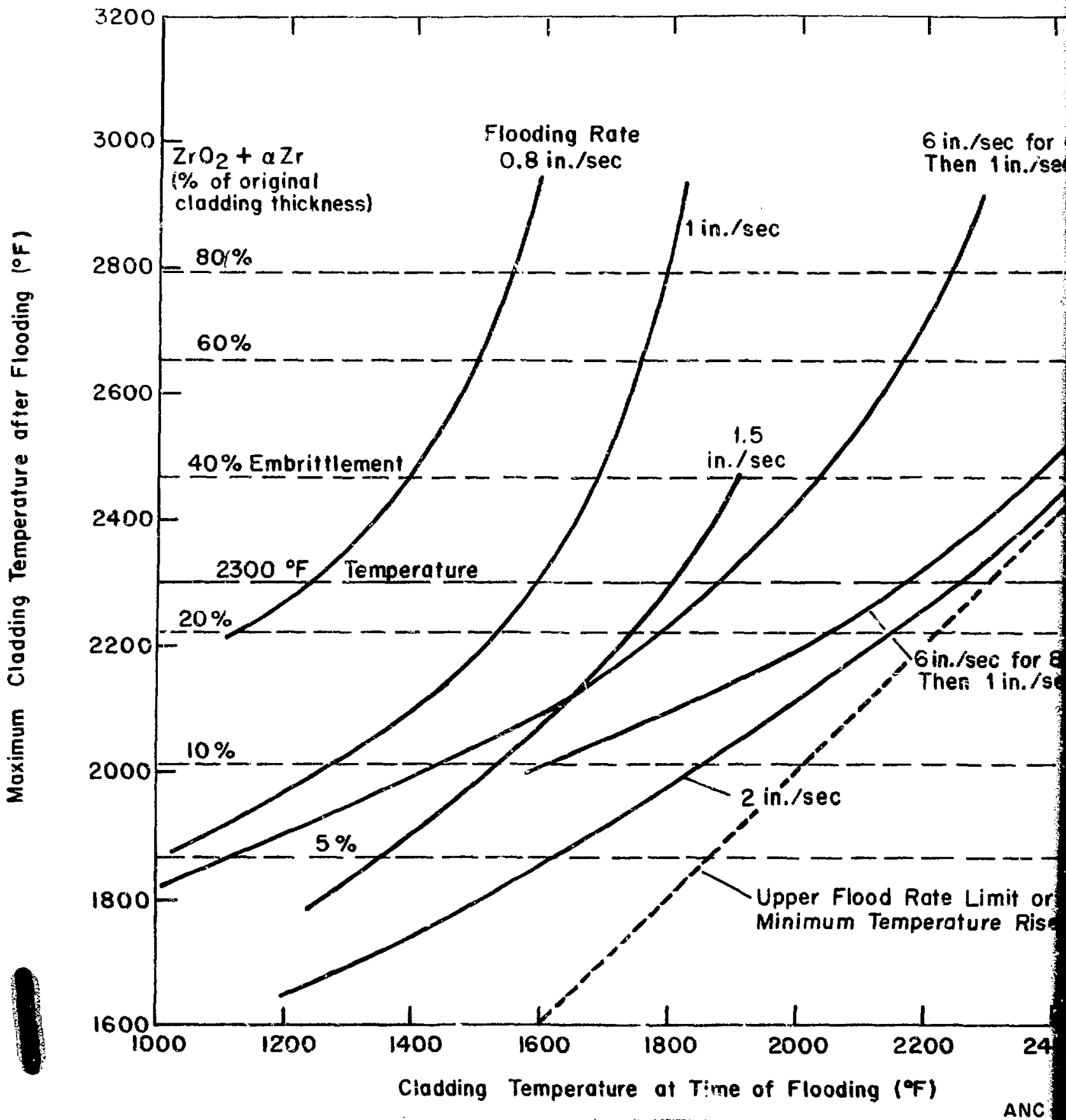

Fig. 12 PWR-ECC performance map obtained through use of PWR-FLECHT data.

and the reflooding rate is $\mathrm{J}$ in./sec, a $1500^{\circ} \mathrm{F}$ temperature at reflood initiation would result in a maximum tem above the value obtained from Figure 12.

Calculation of Reflooding Rates

A reflood computer program, FLOODl, recently developed by Aerojet Nuclear Company for the AEC $h$ calculate avcrage reflooding rates. This program uses a rclatively straightforward approach in which the hop pre accounted for ir the continuity of mass equation. The primary system is modeled as a resistance network and, the include system flow oscillations. The analysis starts at the time the water level reachea the boltom of the core. Thy assumed to flow into the downeomer region with no interaction with the steam flow. The liquid earryover fract the ratio of the mass leaving the cors: to the mass ontering lle eore, is an inpul variable normally set to $5 \%$ until the the core reaches 6 inchers. When the lipuid height in the eore: reaches 6 inches the fraction is assumed to increa until it aprals (0.80) at a horght of 12 inclies. For herights above 12 inches, a constant fraction equal to 0.80 is use Fraction, which is based on datu oblained from the PWR.FI.FCHT experiments, has been corrected to account actual furl rod inemperatures at the core entrame: may be higher than those in the PWR.FLECHT experiment. cau be performed on the carryover fraction by variation of input parameters. In the FLOON1 analytical model 


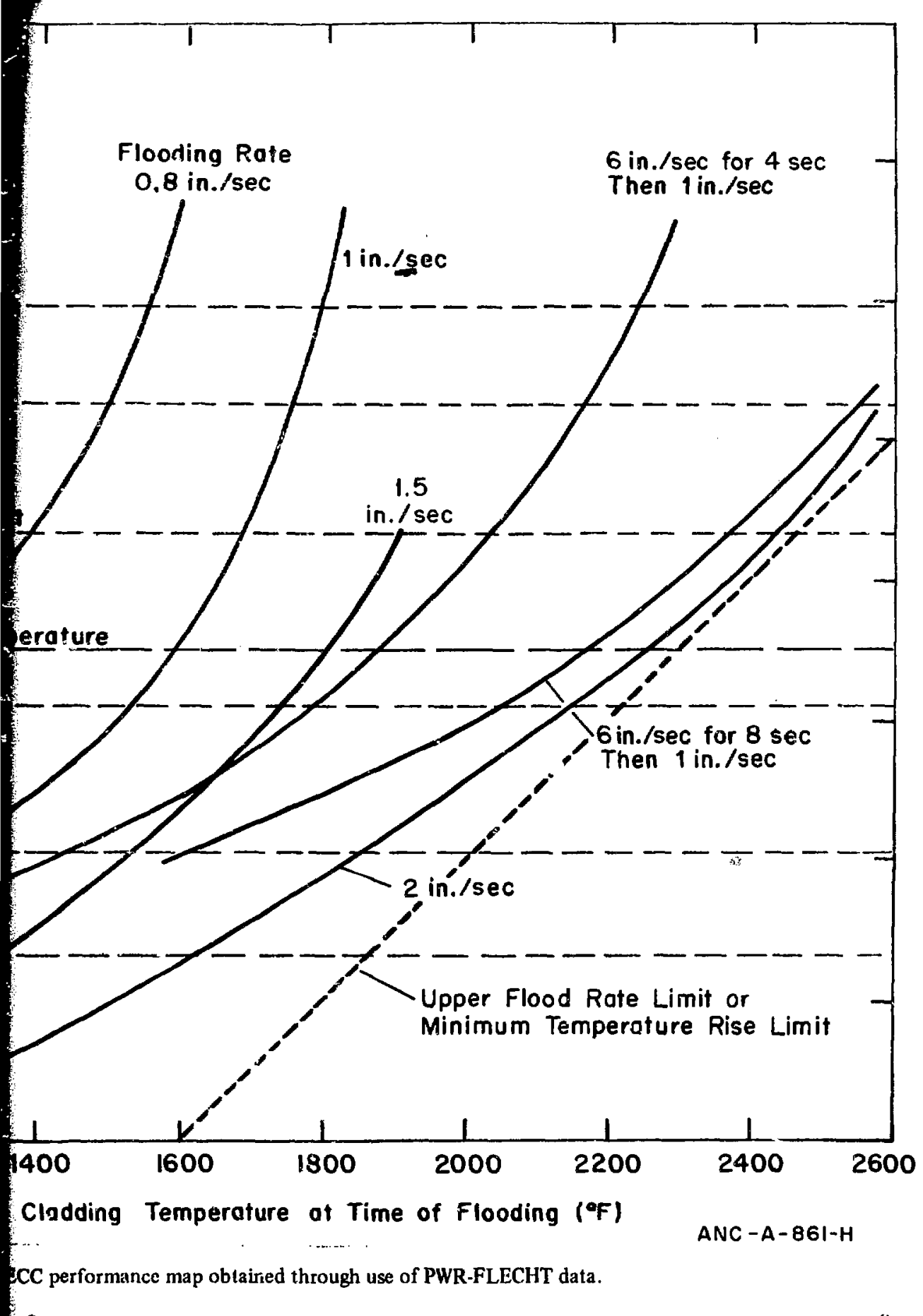

$0^{\circ} \mathrm{F}$ temperature at reflood initiation would result in a maximum temperature $500^{\circ} \mathrm{F}$

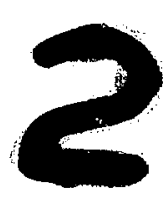

DDl, recently developed by Aerojet Nuclear Company for the AEC has been used to ogram uscs a relatively straightforward approach in which the loop pressure drops are uation. The primary system is modeled as a resistance network and, therefore, denes not sis starts at the time the waler level reaches the bottom of the core. The BCC injereted is on with no interaction with the stcam flow. The liyuicl carryover fraction, expressed as mass entering the vore, is an input variable normally sel to $5 \%$ until the liquid height in height in the core reaches 6 inches the fraction is assumed to increasc: exponentially 2. For heights above 12 inches, a constant fraction equal to 0.80 is used. This carryover from the PWR-FI.FCHT experiments, has been corrected to aceount for the fact that trance may be higher than those in the PWR-FLECHT experiment. Parameter studies by varialion of input parameters. In the FLOODI analytical model, the annulus and 
Paranetor. Value

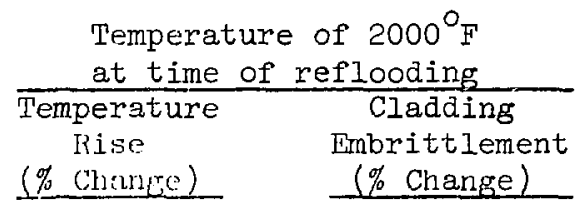

Temperature at tine of $r$

Temperature Rise

(\% Change)

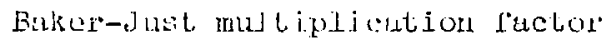

$$
\begin{aligned}
& =0.5 \\
& =1.0
\end{aligned}
$$

$-21$

55

$-56$

106

$=1.4$

$\mathrm{ZrO}_{2}$ thickness (in.) $=0.001$

$=0.00001$

7-sec delay in time to initiate

reflooding [a]

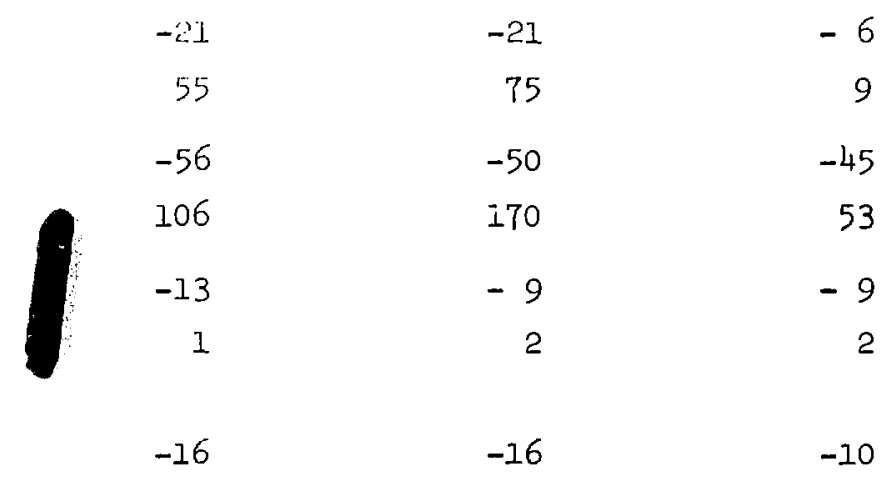

$-6$

9

53

$-9$

$-10$

[a] Delays in flooding initiation result in a reduced temperature rise at any given tempe flooding initiation because the decay power is decreased.

core: bypass regions are viewed comeplually as one leg of a manometer in which water levels are computed, the other leg. Pressure: drops due to flow lhrough the unbroken loop to the inlet annulus are balauced by the differ water in the manomeler legs.

Calculations of reflooding rates using FLOOD1 oversimplify the complex events which occur during the ref. an I.OCA. Use of this code in calculations of average reflooding rates is possible even though the dynamic effec oscillations) are not correctly predicted because of the generalized treatment of the controlling phenomena.

Figtre 13 shows the reflooding rates derived from the application of this FLOODI code to a four-loop PWR are presented to show the effect of several different assumptions which could characterize system resistances behavior. Assumptions common to all of the risults shown on Figure 13 are a system pressure of 50 psia, o injection system operational, and a fluid temperature of $500^{\circ} \mathrm{F}$ in the steam generator secondary side. Cus refloodinen rate as a function of time based on the assumplion that the accumulaturs empty 14 seconds after refloo no pluguing effect of liCC and with the punp rosistance corresponding to a pump operating with a flow res between frec wheling and locked rotor incompressible. flow values. The maximum value of the reflooding rate fre three seconds is $7 \mathrm{in.} / \mathrm{se}$. Curve 2 is hased on lle same input parameter as Curve 1 exeept the pump resistance is locked rotor value. Curve 3 shows the effect of assuming that while the accumulators are discharging, the cold leg loop is plugered will water. Curve 4 sloows the effeot of aceumulators emptying prior to reflood initiation. In th pressure injertion system is the only souree of fluid in the downeomer.

To ust the reflooding curves on Figure: 13 to determine approximate relationehips betwcen initial trmperatures on Pipure 12, the longer term rates are treated as steady state values. Curve 1 (1/2 stoppe approximately correspond to a constant reflooding rate of $1.75 \mathrm{in} . / \mathrm{see}$. Curve 2 (fully stopped pump) would cor of aboul 1.4) ir./see and Curve 3 (pipe plugging) would correspond to a rate of about $1.3 \mathrm{in} . / \mathrm{sec}$. The most (aremumliturs depleted prier to reflooding) would be equivalent to a constant reflood rate of about $0.7 \mathrm{in} . / \mathrm{sec}$.

\section{BUIINC: WTHE RFAC.TOR FCC.S PHEFORMANCE}

This sertions pwoviles performaner information for BWR cores following ECC system actuation. Informatid.

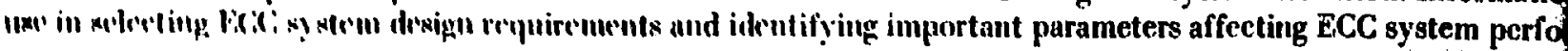




\begin{tabular}{|c|c|c|c|}
\hline \multicolumn{2}{|c|}{$\begin{array}{l}\text { Temperature of } 2000^{\circ} \mathrm{F} \\
\text { at time of reflooding }\end{array}$} & \multicolumn{2}{|c|}{$\begin{array}{l}\text { Temperature of } 1600^{\circ} \mathrm{F} \\
\text { at time of reflooding }\end{array}$} \\
\hline $\begin{array}{l}\text { Temperature } \\
\text { Rise } \\
\text { (\% Chance) }\end{array}$ & $\begin{array}{c}\text { Cladding } \\
\text { Embrittlement } \\
\text { (\% Change) }\end{array}$ & $\begin{array}{l}\text { Temperature } \\
\text { Rise } \\
(\% \text { Change) }\end{array}$ & $\begin{array}{c}\text { Cladding } \\
\text { Embrittlement } \\
\text { (\% Change) }\end{array}$ \\
\hline$-2 \perp$ & -21 & -6 & -9 \\
\hline 55 & 75 & 9 & 12 \\
\hline-56 & -50 & -45 & -61 \\
\hline 106 & 170 & 53 & 101 \\
\hline-13 & -9 & -9 & -8 \\
\hline 1 & 2 & 2 & 2 \\
\hline-16 & -16 & -10 & -15 \\
\hline
\end{tabular}

esult in a reduced temperature rise at any given temperature at redecay power is decreased.

as one leg of a manometer in which water levels are computed, the core being the h the unbroken loop to the inlet annulus are balanced by the differential height of

FLOD 1 oversimplify the complex events which occur during the reflooding phase of if average reflooding rates is possible even though the dynamic effects (for example, ise of the generalized treatment of the controlling phenomena.

rived from the application of this FLOODI code to a four-loop PWR system. Results different assumptions which could eharacterize system resistances and accumulator te results shown on Figure 13 are a system pressure of 50 psia, one low pressure: emperature of $500^{\circ} \mathrm{F}$ in the steam generator sccondary side. Curve I shows the the assimption that the accumulators empty 14 seconds after reflood initiation with imp resislance corresponding to a pump operating with a flow resistance midway mpressible llow values. The maximum value of the reflooding rate from about one to on the same input parameter as Curve 1 . exeept the pump resistanee is increased to the of assuming that while the accumulators are diseliarging, the cold $\mathrm{leg}$ of the operating he effect of aceumulators emptying prior to reflood initiation. In this case, the low fluid in the downeomer.

gure 13 to detorınine approximate relationships between initial and maximum in rates are treated as steady state values. Curve 1 (1/2 stopped pump) would ooding rate of $1.75 \mathrm{in} . / \mathrm{sec}$. Curve 2 (fully stopped pump) would correspond to a rate - Iuging) would correspond to a rate of about $1.3 \mathrm{in} . / \mathrm{sec}$. The most significant effect ould be equivalent to a constant reflood rate of about $0.7 \mathrm{in.} / \mathrm{sec}$.

RMANCE

Imation for IBWR cores following ECC system actuation. Information is provided for ts und ikkutifying important parameters affecting ECC system performance. 


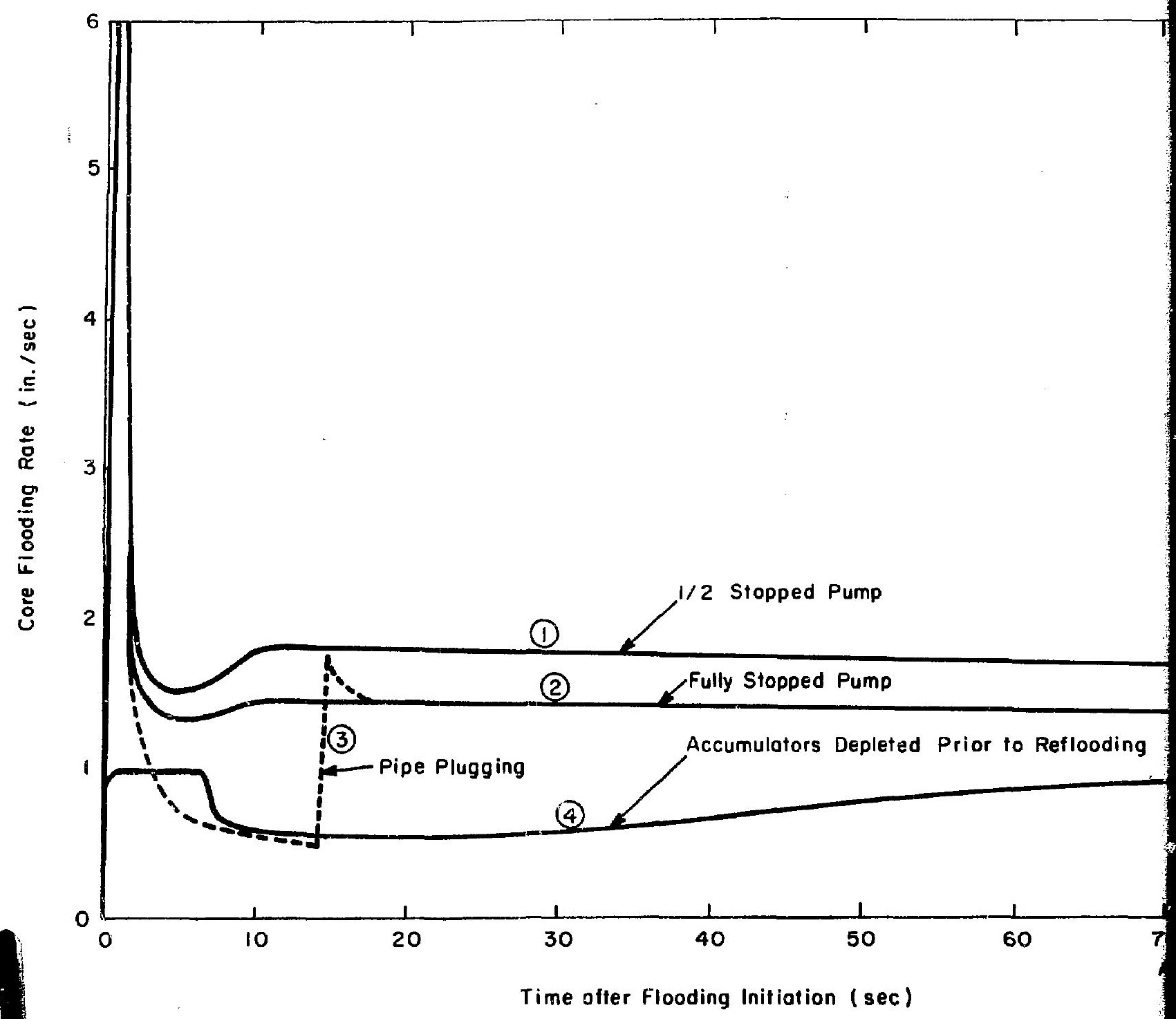

Fig. 13 PWR reflooding rates--parameter study using FLOOD1.

\section{Source of Heat Transfer Coefficient for Study}

The primary source of experimental information on BWR-ECC systems (spray and reflooding) has been BWR-FLECHT ${ }^{6}$ program. The basic test assembly for this program employed 49-rod bundles of stainless stee: heated fuel rod simulators. The rods were 12 fcet long, located on typical BWR spacing, and enclosed by a shro results were obtained during both bottom flooding and top spray injeetion for various bundle powers, flow rat initial temperatures. 'The: bottom flooding test data were applied in a manner similar to that discussed in the pre PWR-HLLC.IIT data. Bheause of the relatively sumall convective heal transfer coefficients associated with spray large: radial power and resulting lemperature gradients wilhin a IBWR. bundle, the heat transfer coefficients for s: aifeulaled difficrently than thase lor lhe peflocenting experiments. "The data reduction process ineluded a radiatif delarmine rod-to-rod and rod-lo-ranisler mdiant heal fluxes. These heat fluxes were then used in conjunction ws lolal heal fluxes to whtain focal ronveretion heat trenster cocfficients. Correlations of convection coefficients th conumonly used as iupu. to multirod codes to calculate the performance of nuclear rod bundles during spray cooli

\section{Application of BWR-FI,ECIFT Results to Simulate BWR Core Performance}

The MOXY code ${ }^{13}$ was used for condueting the ECC performance studies in this section. This code employ bunde that deserilo heat transfer by thermal radiation, conduction, and convection, and heat generation by me mul loy fission product decay. For the ovaluation performed in conjunction with this paper, the MOXY code typical IBWR. opernting anditions, and blowdown heat transfer cocefficionts and power decay were provided calculations, the spray sydem was netunted 40 seconds after blowdown was inilinted. $\Lambda$ this time the BWR-FLE 


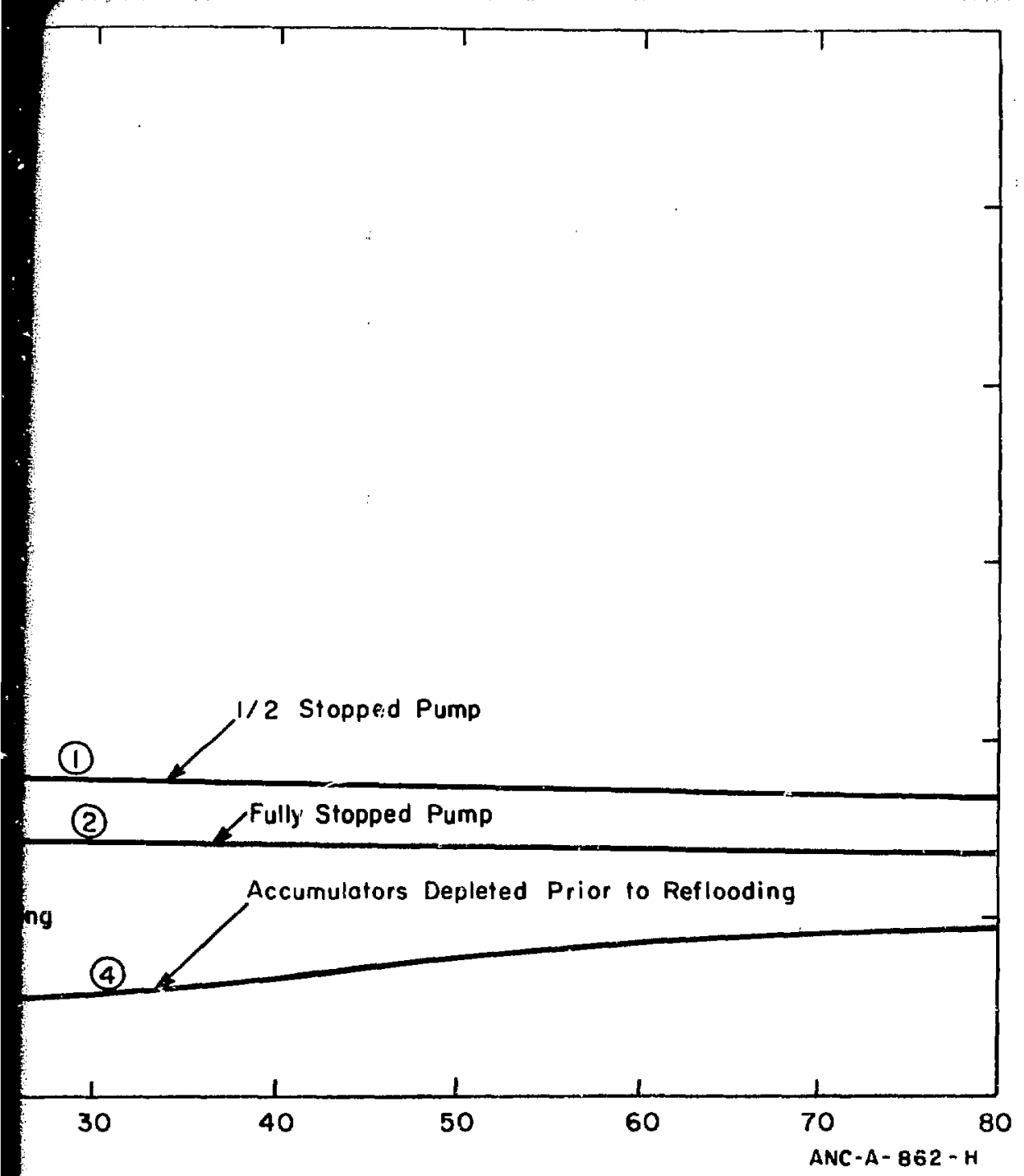

Time after Flooding Initiotion (sec)

$\mathbf{R}$ reflooding rates-parameter study using FLOOD1.

jrmation on BWR-ECC systems (spray and reflooding) has becn obtained from the: mbly for this program employed 49-rod bundles of stainless stecl-clad, electrically feet long, located on typical BWR spacing, and enclosed by a shroud. Experimenta? bding and top spray injection for various bundle powers, flow rates, pressures, and data were applied in a manner similar to that diseused in the previous section for small conveetive heal transfer cocfficients associated with spray cooling, and the radients within a ISWR bundle, the heal transfer coefficients for spray cooling were: coding expreriments. The data reduction process included a radiation calculation to at heal fluxes. 'These: heat iluxes were then used in conjunction with individual rod zal tramsicr coclficients. Correlations of convection coefficients thus derived 12 are falculate the performance of nucles rod bundles during spray cooling.

\section{lute BWR Core Performance}

ing the ECC performance studies in this section. This code employs models of a rod radiation, conduction, and convection, and heat generation by metal-water reaction tion performed in conjunetion with this paper, the MOXY code was initialized at lown heat transfer coefficients and power decay were provided as input. For all meconds afler blowdown was inilinted. At this time the IBWR.FLECITT heat trsnsfer 
convertion correlations were used to provide the thermal response for spray-on conditions. A representativ transfor beharior for the accident is shown in Figure 14 in which a base case and one conservative variation, 1 rontributed by flashing of the fluid in the lower plenum, are presented. The heat transfer eharacteristies, sleady and the decas heat function are the only inputs repreired in a ty pical MOXX calculation. The physical geometry metal-water reaction contribulion, and other pertinent fratures are incorporated into the code.

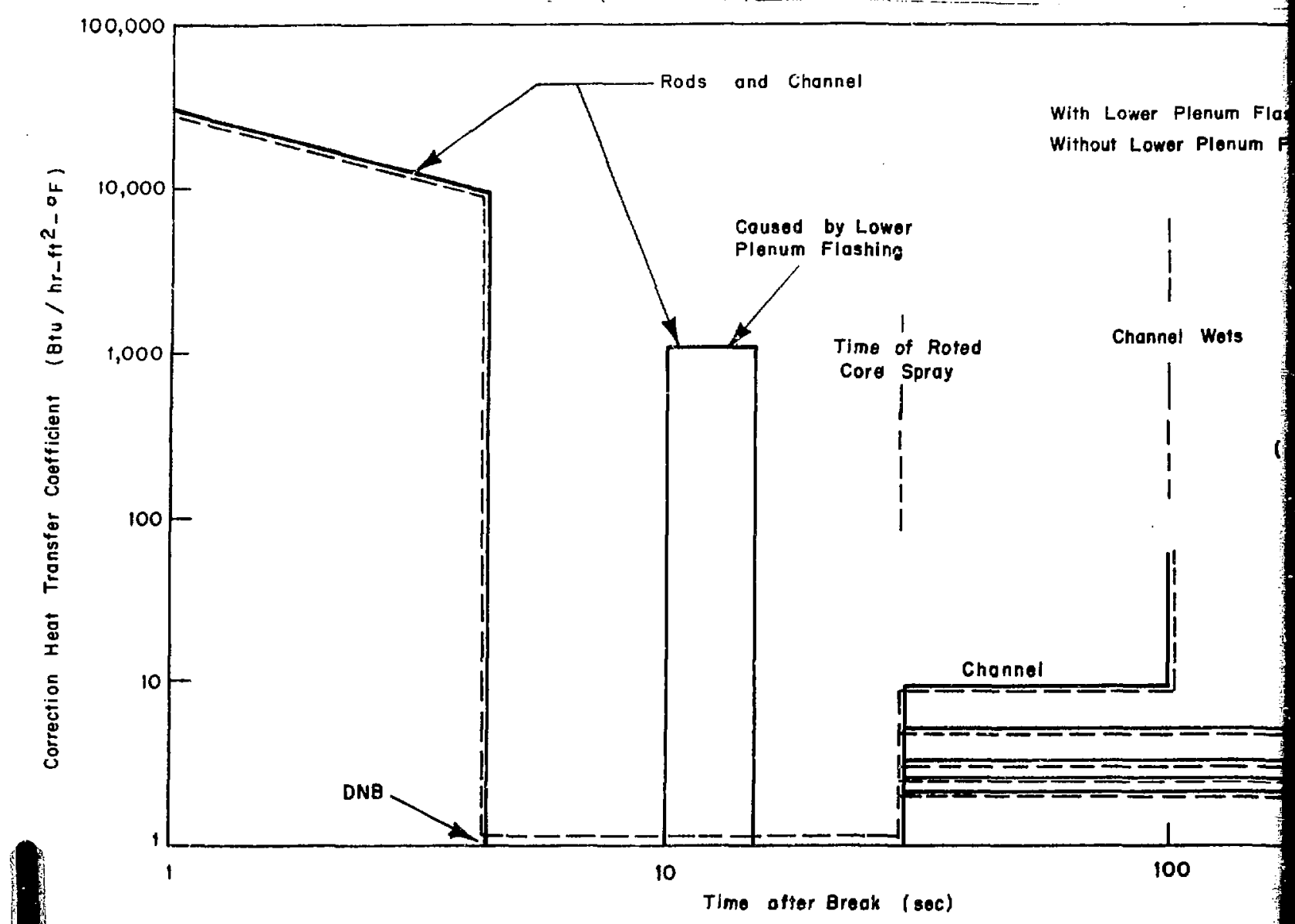

Fig. 14 Two case assumptions of BWR-LOCA heat transfer coefficient response.

The calculated transient bundle responses, as represented by the temperature-time responses of three ro presented in Figure 15. Oniy top spray cooling has beren used in these calculations because the temperature tr, to be terminated when the core becomes flooded by liquid accumulated in the lower plenum. Because of designs. pump sizes, and assumptions of liquid inventory remaining at the end of blowdown, the time considerably, and has been left as an independent variable. The curves in Figure 15 represent typical output The sensidivity of the ealculated bundle temperature response has been investigated separately on a parametri Power levels, decay power curves, metal-water reaclion rates, and other variables all are important in the calcula

AI array of curves, such as shown in Figurs I5, was generated by varying blowdown heat transfer ratea $\mathrm{i}^{\mathrm{t}}$ a BWR performance inap. This map, Figure 16, presents the loci of maximum bundle temperatures as a functs temperalure at time of ECC injection (top spray inilialion) for given time delays to flooding initiation. The re map has becre eompleted by inclusion of percentage emblettiement lines also obtained from the MOXY calculat?

Figure 16 shows that if the eladding temperature is $1600^{\circ} \mathrm{F}$ at the time of spray initiation and flooding laler. a nuximum temperalure of $2030^{\circ} \mathrm{F}$ and an embritilesnent of about $5 \%$ would occur. Thus. this partic have a $270^{\circ} \mathrm{F}$ temperature margin and a: iproximutely a $35 \%$ embrittlement margin.

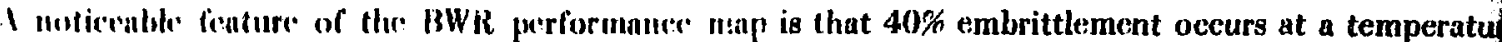

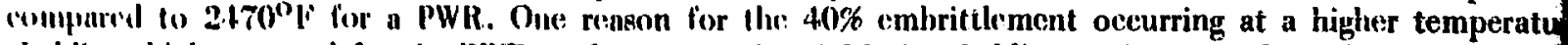

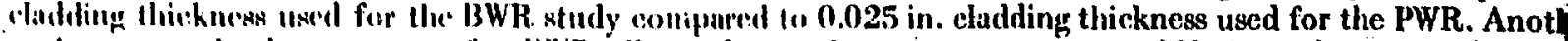

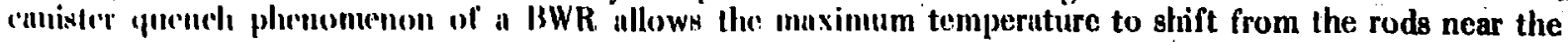
Iransin! to the eentral resls later in the transient (Figure 15); the PWR analyais considered only one rod throu? 
the thermal respense for spray-on conditions. A representative plot of the hrat Figure 14 in which a batse case and one conservative variation, loss of heal transfir zer plenum, are presented. 'The heat transfer eharacteristics, sleady state power levels, ats recpuired in a typieal NOXY calculation. The physical geometry of the' system, Ilif pertinent fratures are incornorated into the code.

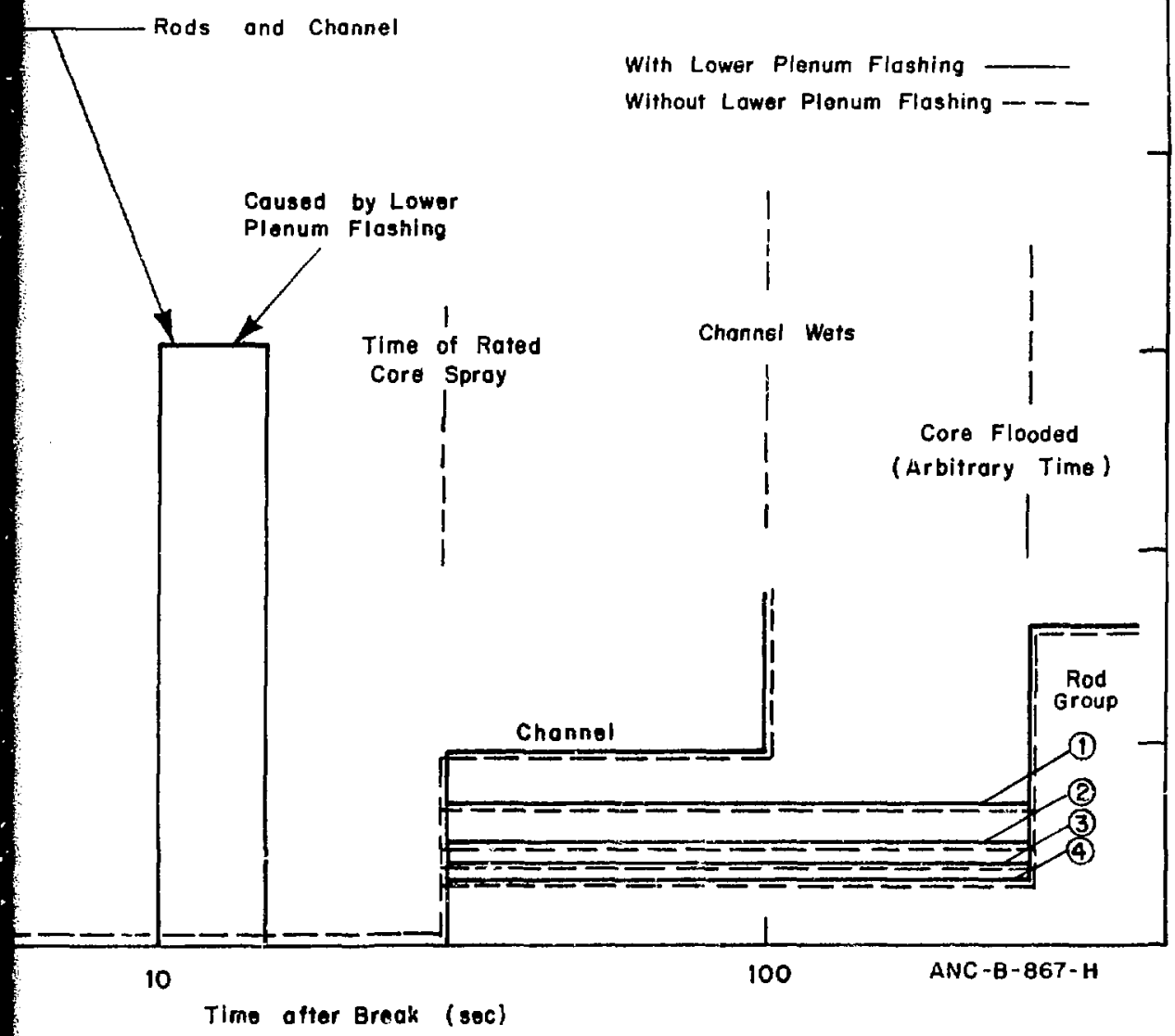

assumptions of BWR-LOCA heat transfer coefficierıt response.

3es, as represented by the temperature-time responses of three, rods in the bundle, are ing has bren used in these calculations because the temperature transient was assumed ooded by liquid accumulated in the lower plenum. Because of differences in plant quid inventory remaining at the end of blowdown, the time of flooding varies dent variable. The curves in Figure 15 represent typical output of the MOXY codrs. perature response has been investigated separately on a parametric basis by Evans. 14 reaction rates, and other variables all are important in the calculation.

gure: 15, was generated by varying blowdown heat transfer rates in order to construct 6, presents the loci of maximum bundlo temperatures as a function of initial bundle pray initialion) for given time delays to flooding initiation. The resulting performance fntage combrittlement lines also obtained from the MOXY calculations.

mperature is $1600^{\circ} \mathrm{F}$ at the time of spray initiation and flooding oceurs 100 seconds al an embrittlement of about $5 \%$ would occur. Thus, this particular transient would mately a $35 \%$ embrittlement margin.

ormanec mnp is that $40 \%$ embrittement occurs at a temperature of about $2870^{\circ} \mathrm{F}$ for lle: $0 \%$ embrittlement occurring at a higher temperature is the $0.0315 \mathrm{in}$. musared lo 0.025 in. clindding thickn'ss used for the PWR. Another reason is that the ws the maximum temperature to shift from the rods near the canister early in the int (Finure I5); the PWR analysis considered only one rod throughout the transient.

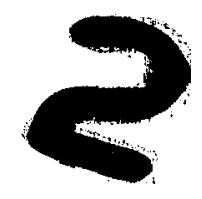




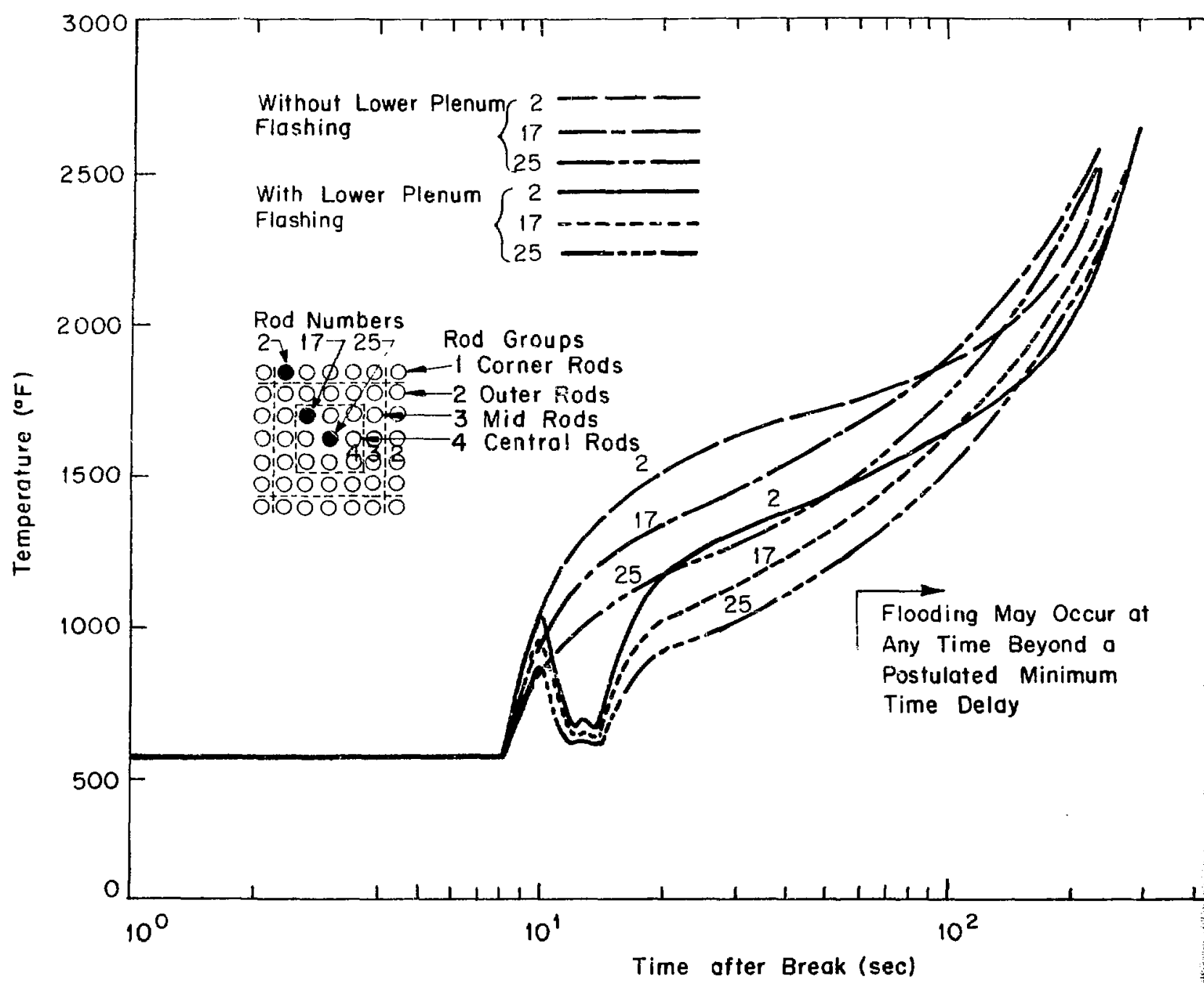

Fig. 15 Calculated BWR transient temperature response for two case assumptions of LOCA heat transfer.

\section{RESEARCH AND DEVELOPMENT RELATED TO EMERGENCY CORF COOLING}

Ultimately, safely assessment of large power reaciors must he derived from:

(1) The: devolopment and application of' a syslem of analyses which can destribe the complex transient highly interacting array of events in the lose of-coolant accident with sufficient precision to quantif thr. adequacy of emergency safety systems for terminating the fucl cladding tempcrature rise and t? quantify the margins to cladding failure

(2) The design and conduct of exporiments from whish data can be applied loward a meaningfu assessment of the capubility, completeness, and adequacy of the anlytical techniques used to predic

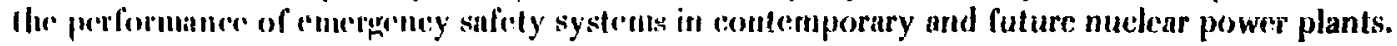

The adepuacy of the enrrent analysis methods is umertain in some important areas as a result of: (a) developing the analysis for certain heat transfer processes from first principles; (b) the simplifying assumptions an represulitions neressury to maintain the digital computer techniques manageable and conomical; (c) the la cmpirical datil for correlations which musi substitute for basic analytieal relationships; and (d) the laek verificalion of lle analysis thromgh lists of representative systems which reproduce all important, controllin: efferts.

In order for the analysis to approach rapidly the desired level of precision and confidence, the developmet. and the arequi,ition of axperimental data must procend logether .. each supplying the other with direction and con 


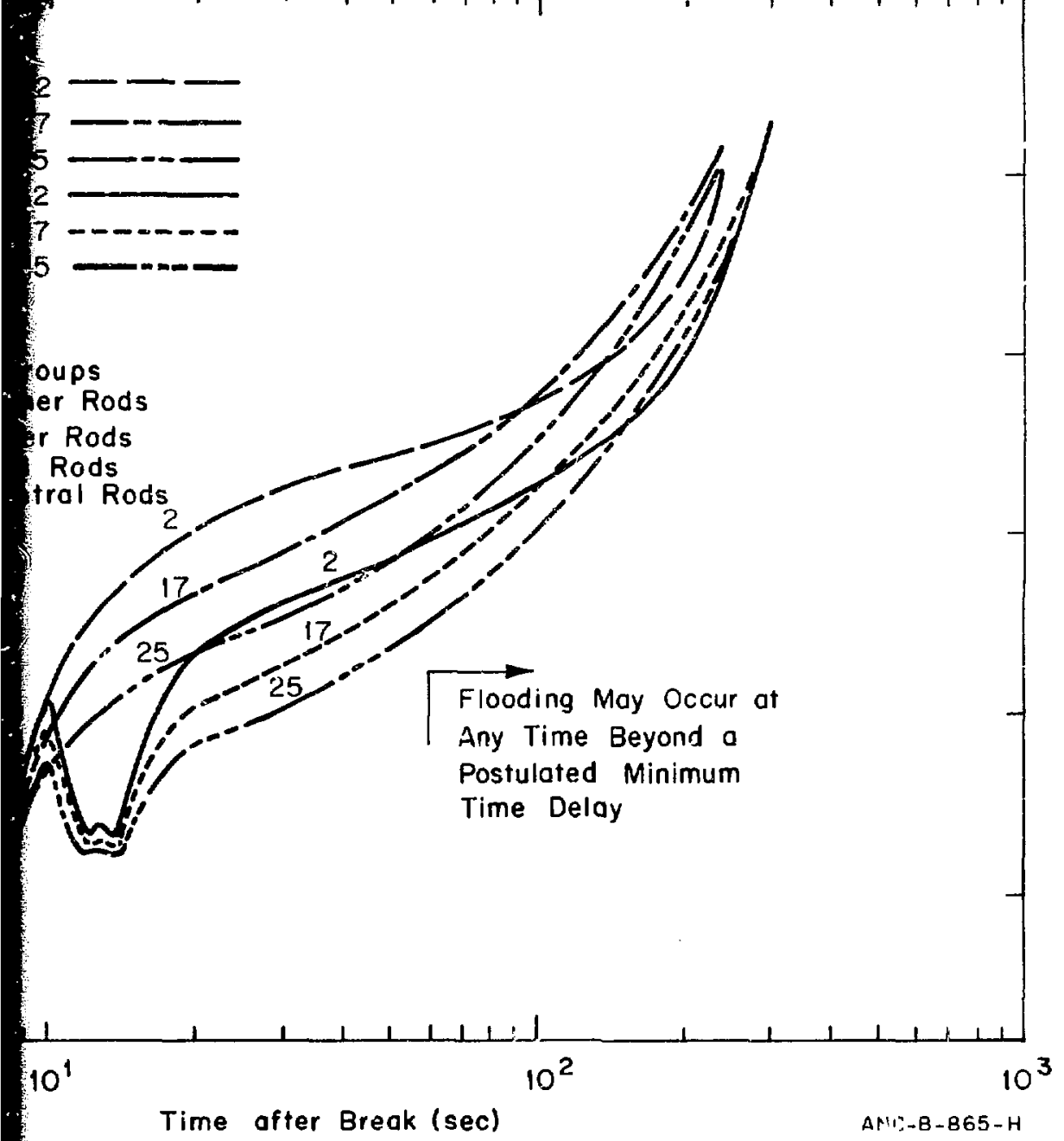

emperature response for two case assumptions of LOCA heat transfer.

\section{SLOPMENT RELATED TO EMERGENCY CORE COOLING}

ir reaclors must be derived from:

a system of analyses which can destribe the complex transicent, the loss-of-coolant accident with sufficient precision to quantify ystems for terminating the fuel cladding temperature rise and to re

iments from which data can be applied loward a meaningful tenc'ss, and adeciuacy of the anlytical techniques used to pirediel syrtems in contemporary and future nuclear power plants.

thods is Imerrain in some important areas as a result of: (a) the difficulty in rovesses from first principles; (b) the simplifying assumptions and lumped-system 1 computer techniques manageable and economical; (c) the lack of applicaible bstitute for basic analytical relationships; and (d) the lack of experimental esentalive systems which reproduce all important, controlling, and interacling

y the desired level of precision and confidenee, the development of the analysis eoed logether ... each supplying the other with direction and eonfirmation. 
Maximum Cladding Temperature after ECC Injection ( $\left.{ }^{\circ} \mathrm{F}\right)$

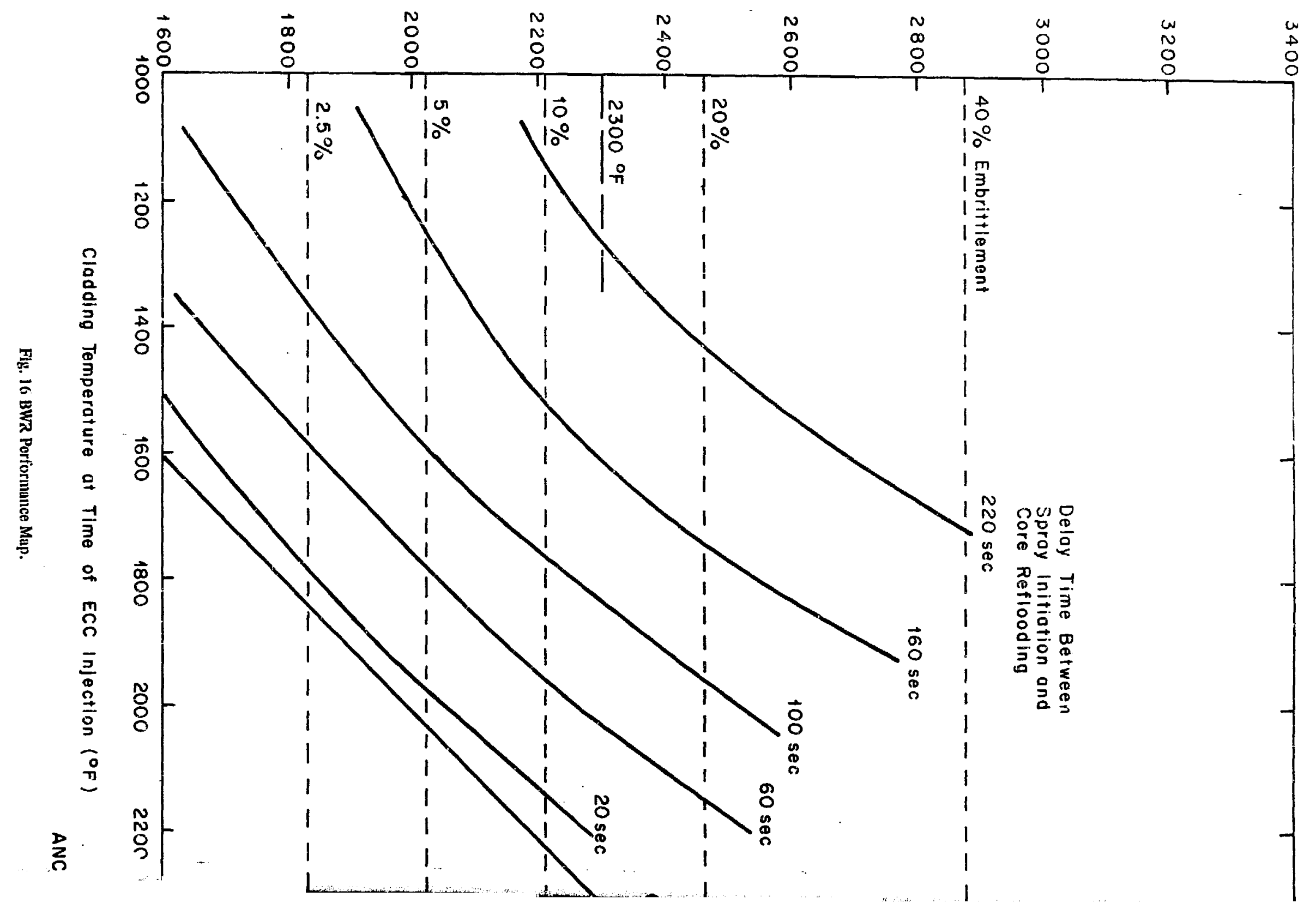




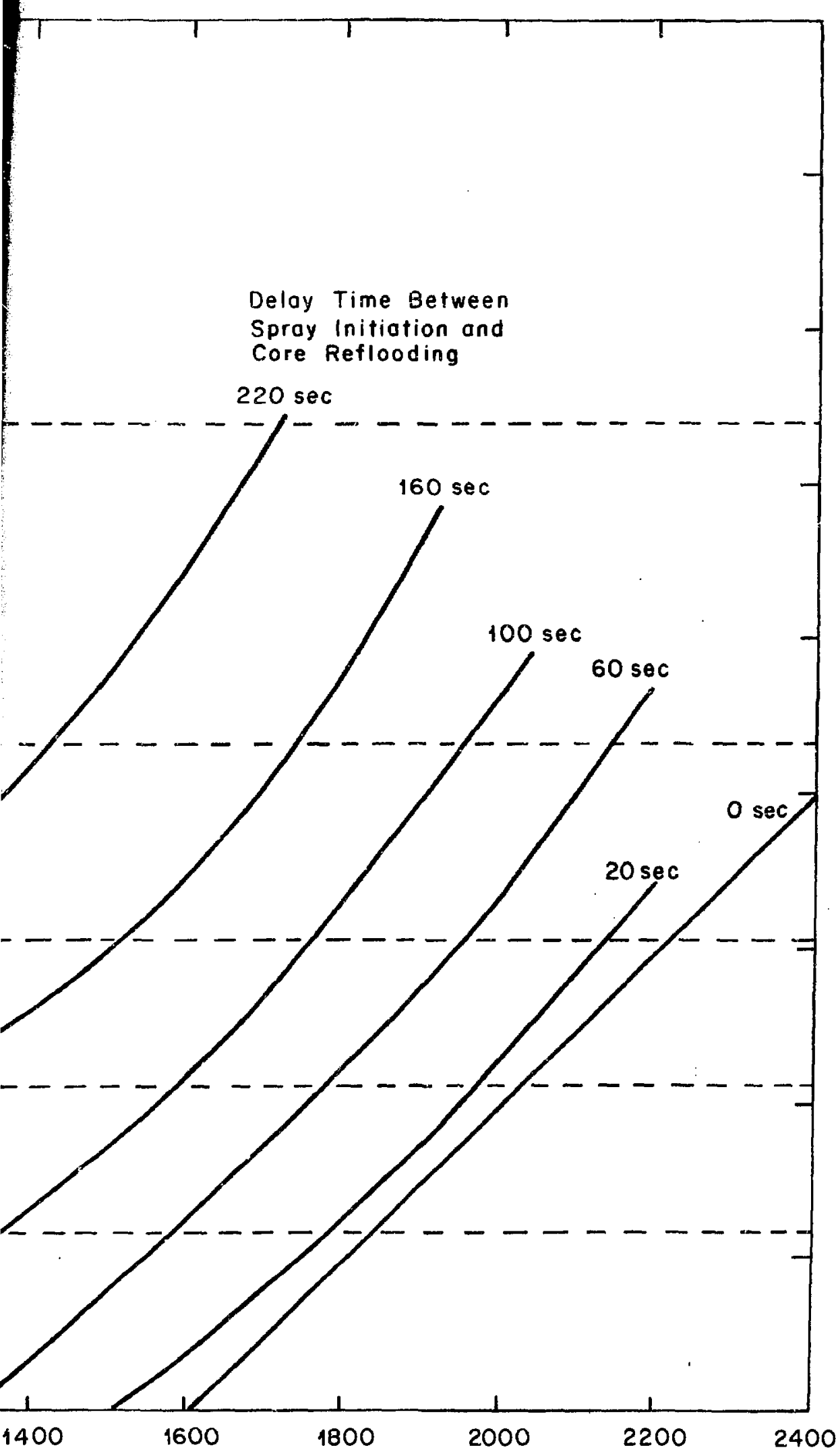

Spray Initiation and Core Reflooding 
A summary of the eurrent analysis methods under development. refinement. and verifieation is included and is followed loy a listing summarizing the various related experimental programs dealing with the loss-of -reolate

\section{ANALYYIS IEVELOPMENTS}

Current analyses use digital computer codes together with simplifying assumptions to solve the ba' conservation of mass, momenlum, and energy of the system eoolant. The reactor coolant circuits are modeled bs fluid "eontrol volumes" to which the conservation eyualions are applied. The computer models (codes) ma

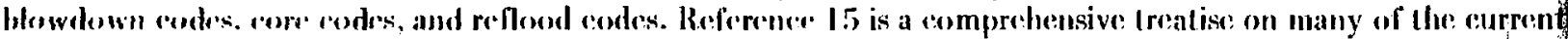

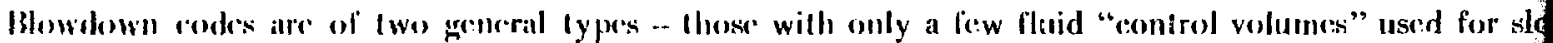

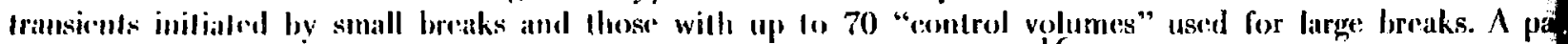

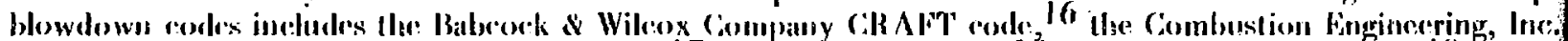

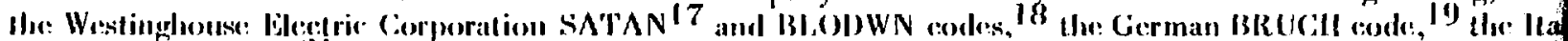

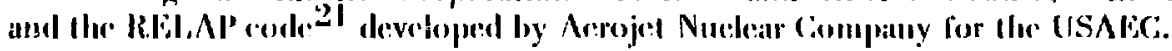

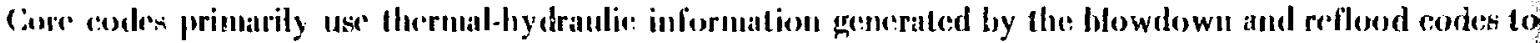
calculalion of llye core llow history and resulting futel dadding temperature. Single-flow-channel core Westinghuuse Elretric Corporation LOCTA-R2 code, ${ }^{22}$ the Danish DINO code, ${ }^{19}$ and the Aerojet Nuclear code. ${ }^{23}$ Multichamel core codes have been written to allow interchannel flow caused in part by such ballooning of the fuel cladding. Currently used multichannel codes include the Westinghouse Electric Corpo CHARM codes, the Battelle Nortliwest Laboratories COBRA code, 24 and the English HAMBO code. ${ }^{25}$ Thr Company codes, MOXY, ${ }^{13}$ RADHT, and STAB, ealculate in two-dimensions the rod-to-rod radiant energy in bundle al onr axial elevation. RADH'T is a steady state version of MOXY, whereas STAB is the RADHT code radiation inforehange between the rods and steam in the ehannels.

The blowdown and core codes have the dilficult task of predicting the all important magnitude of fuel cl at the time of reflooding initialion. As diseussed in the previous scelion and developed in some detail in App removed from the corc during blowdown, particularly for the large inlet break in a PWR, depends heavily up which influence the core flow and vessel fluid state throughent the entire blowdown process. The calculation become more complicated by the inje:tion of emergency ecore coolant which is at a temperalure and velocity from that existing in the primary system at the BC.C injection port. At present the conventional codes are some of the sublletics because they inciude simplifying assumptions such as:

(I) Momentum flux terms in the momentum equation can be neglected

(2) Core heat transfer has negligible effect on the core flow

(3) No energy exchange betweon the fluid and the structural material

(4) Water and steam velocilies are identical and water and sfeam temperatures are identical

(5) Flow divisiens can be represented by one-dimensional equations

(6) Performance of the primary system pumps can be predieted from pump data taken in liquid-only loops.

"The current sysing codes are able to predict the trends of such data as that obtained in the semiscale bl heated-iore lests ${ }^{20}$ but. Generally, whereas one parameter such as pressure may follow close to the experin parameter such as rore iulet densily may deviatc contiderably.

Reflood code development has lugged blowdown code development. In general, the current reflood co udepuately the conservation equalions or they use simple approximations with weak conpling between the eq Nuelear Company FIOODI, UKAEA CLADFI,OOD, 7 and the Westinghouse Electric Corporation reflood es flow approximutions from the PWR-FIBCIIT'5 ixperimenlal data. All inree codes represent the primary loe rexistances willont ureounting for fluid, inertin und system volumes. The Babcock \& Wilcox Company RËFL Combuslion lingincering, lno., PlikC code inchude the primary system volumes and fluid inertia as well as inc

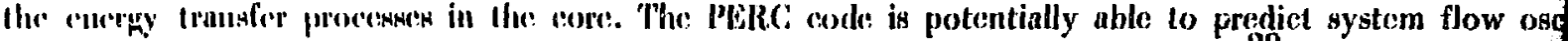

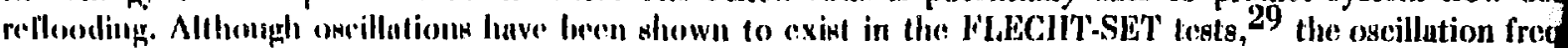

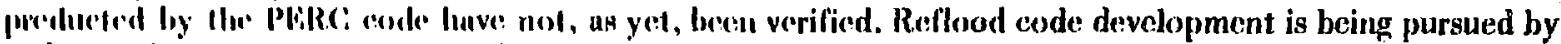
aul manufarlurers in many eomufrie's. 
As indicaled ly the fault tree diacussed previously. the inmorlant variables which the aodes musl prediet certainty are: (a) the coolant flow and enthalpy available to the core region and whirh control the energy removal (b) the coolant efflux rate at the break which controls the duration of the blowdown, (c) the RCC inter: decompressing fluid, and (d) the cladding temperature resulting from the influence of the forcgoing variable Although the rodes have not demonstrated the capability to predict adequately these variables. recent refinemen and more comprehensive system experiments are expected to provide for critical comparisons in the near future.

\section{EXPERIMENTAI, PROGRAMS}

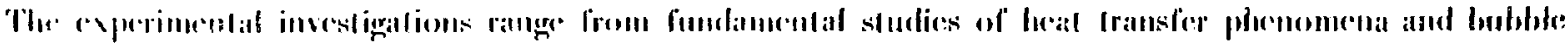

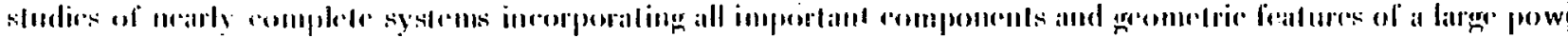

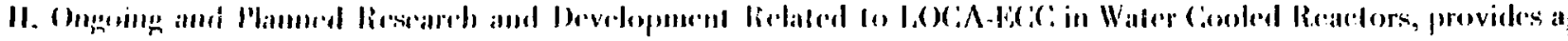

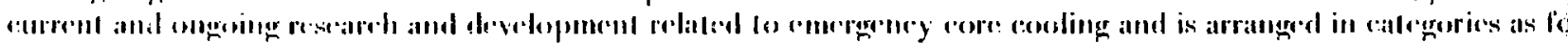

Fumdamental Sludies in BBlowdown and Iloal Transfer

Fmergeney Core Coolant Delivery

Reflooding Heat Transfor

Sraled System Effeets Experiments

Large-System Effects Experiniants with Nuclear Ifeat Souree.

The table shows the programs and their sponsors, lioe purpose of the investigations, experimental system descrip and renarks relating to the emphlasis of the experimental artivities. An identifying code name is provided for order that Table 11 in:ly be cross-freferenced to al second dable, Table III.

\section{'ABLE II}

ONGOING AND PLANNLD RIBEARCH AND DEVELOIMENT RELA'TED TO LOCA-FCC IN WATER COOLED REACTORS

\section{PROGRAM}

Fundamental

Studies in Blowdown and Heat Transfer

1. PWR blowdown heat transfer (USAEC, ORNL)
$7 \times 7$ electrically heated Continuing rod array 12-ft-long, pro- to July filed power distribution, 1975 PWR pin diameter and pitch.

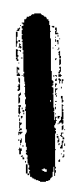
$t$ ion and on heat transfer related to operational upsets.

\section{EXPERIMENTAL SYSTEM}

2. Invostigation of I'ressure Drops and Heint Irumsier coef'fliclonts (USAR!, Hniverajily at cituclmati)
U. $\operatorname{cin} /$ AE:

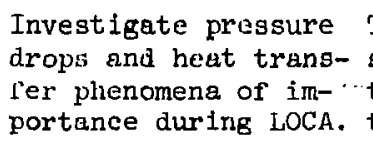

I'wo laboratory scale test systems: (1) small piping test section using freon to obtain two-phase pressure drops and flow pat-. terns, and (2) a single tube with mercury on the inside to obtain basic transition bolling and reflooding heat trans- 
viously, the important variables which the codes mess predie with reasonalale vailable to the core region and which control the energy removal from the core, controls the duration of the blowdown, (c) the ECC interaction with the: erature resulting from the influence of the foregoing variables or processes. apability to prediet adequately these variables, recent refinements in the codes xpected to provide for critical comparisons in the near future.

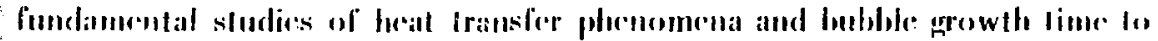

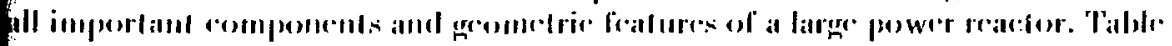

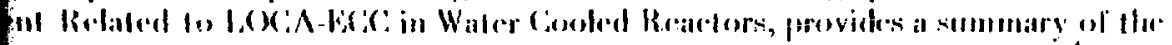

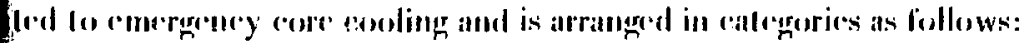

I'ransfir

\section{ear Ifeat Source.}

the purpose of the investigations, experimenlal system deseriptions, references, brimental activities. An identifying code name is provided for each promram in ond table, Table, III.

\section{I'ABLE' II}

DIVELOPMENT RELATED TO LOCA-ECC IN WATER COOLED REACTORS

low-

ter

ec-

to

ts.

sure Two laboratory scele test

rans systems: (I) suall piping

im- test section using freon

LOCA. to obtain two-phase pressure drops and flow patterns, and (2) a single tube with mercury on the inslde to cbtain besic transition boiling and reflooding heat transPer data.
Continuing

Continuing to July 1975

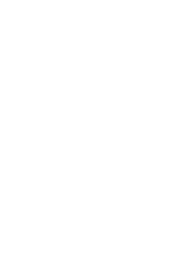

Emphasize separate effects tests on blowdown heat transrer in which response of the rod array to specific initial and boundary conditions (for example, reverse and remeverse flow) will be determined without influence of the primary systen loop.

Fundamental studies to include conditions under which nucleate boiling is reestablished.

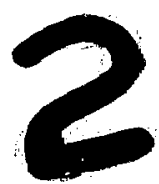




\section{PROGRAM \\ 3. Leficient Cooling, (US- Alic, veneral Electric Com- pany, San Jose, Calif.)}

CODE
GE/DC/
AEC

4. Bjowdiown of Long straiglit Pipes (Risley, UKAEA)

5. Research on Safety Assessment (ROSA) (Japan Atomic Energy Research Institute, Tokai Laboratory)
UKAEA

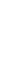

\section{ROSA}

Measure pressure and leak flow transients during blowdown, obtain scoping data on DNB during bjowdown, evaluatepressure oscillations.

\section{EXPERIMENTAL SYSTEM}

Single-rod and 9 (or 15) rod array transient $\mathrm{CHF}$ tests; single-rod simulated swelling effects on steady-state CHF;9rod array with geometry changes on spacer components and simulated bowing and suelling to investigate steadyitate CIIF.

Lonf straight pipes up to 8 in. in aiameter, $12 \mathrm{ft}$ in length, heavily instrumented.

ROSA I: 56-cm-ID and 708cm-long pressure vessel, rod array typical of BWR fuel assembly with up to 13 electrically heated rods, rupture disc unit.

Continuing 32 SCHEDULE

Continuing 30

Trans:

inclu

flow,

presst

study

combit

bundl.

power:

and $\mathbf{s}$

Continuing 31

Studi

minin growt which trol

BWR $-r$ blowd trans part gram. facil fabri. descr scale fects

6. lieat 'Irans-

AEG/GFM Acquire data base for heat transfer fer During Blowdown ( AEG-Te Telefunken, German Federal Ministry)

7. Repressurization Dynamics and Heating Transient, Fundamental TwoPhase Flow Studies (EURATOM, Ispra) coefficients and thermal-hydraulic behavior during blowdown.

Parametric tests with an internally cooled tube $3 \mathrm{~m}$ in length. Test section 4-rod bundle tests using BWR and PWR power profiles and 36-rod bundle tests with BWR and PWR power profiles.

Ispra

Obtain data on heat transfer during

Test loop consisted of an eleutrically-heated roundsystem decompression. tube test section (15-mm OD, 13.8-mm ID, and 3-m length), an upper plenum, a lower plenum, a recirculation line, a pressurizer, and a quick opening valve.

8. Investigation of the Phenomena Involved in the Deprestiulization of WaterCooler Reactor:3 (Batl.rileLustilute in Fraukintet, herineuny $\mathrm{BMI} / \mathrm{GFM}$

BMI/GFM $\begin{aligned} & \text { Determine loads on } \\ & \text { vessel internals } \\ & \text { during depressuri- } \\ & \text { zation, investigate } \\ & \text { phenomena in the } \\ & \text { initial phase of } \\ & \text { iepressurization (in } \\ & \text { particular the ajs- } \\ & \text { chares ratc). }\end{aligned}$

Tesics utilize a vessel of $0.8-\mathrm{m}$ ID and $11.2-\mathrm{m}$ length with simplified internals representation, Exit pipe diameter of $150 \mathrm{~mm}$.
Continuing 33

Perame LOCA C. develo transf

One sut mulati 


\section{URPOSE}

ne CHF and

ture re-

ccurxing

power, flow,

sure tran-

pset; eval-

mperature

in I.OCA;

te conse-

of fuel

metry

b

besic de-

sion data

el develop-

pressure

k flow tren-

during olow-

btain scoping

DNB during

$M$, evaluate-

e oscillations.
EXPERIMENTAL SYSTEM

Single-rod and 9(or 15)

rod array transient $\mathrm{CHF}$

tests; single-rod simu-

lated swelling effects

on steady-state CHS;9-

rod array with geometry

changes on spacer com-

ponents and simulated

bowing and swelling to

investigate steady-

atute CHF.

\section{long straight pipes up}

to 8 in. in diameter,

$12 \mathrm{ft}$ in length, heavily

instrumented.

ROSA I: 56-cm-ID and 708cm-long pressure vessel, rod array typical of BWR fuel assembly with up to 13 electrically heated rods, rupture disc unit.

\section{SCHEDULE REF.}

Continuing 30 Transient CHF tests

incluae transient.

flow, power, and pressure testing and study of effects of combinations of intrabundle clearance, power distribution, and spacer components.

Continuing 31 . Studies for determining basic bubble: growth phenomene which cause and control critical flow.

Continuing 32

BWR vessel system blowdown and heat transfer data as part of this program. A ROSA II facility is being fabricated and is described under scaled system effects experiments.

Parametric tests with an Continuing 33 internally cooled tube $3 \mathrm{~m}$ in length. Test section 4-rod bundle tests using BWR and PWR power profiles and 36-rod bundle tests with BWR and PWR power profiles.

Test Ioop consisted of an electrically-heated roundata on heat during ecompression. tube test section (15-mm OD, 13.8-mm ID, and 3-m length), an upper plenum, a lower plenum, \& recirculation line, a pressurizer, and a quick opening valve.

loads on hternals pressuriinvestigate t in the Shase of ization (in ir the diste).
Tests utilize a vessel of $0.8-\mathrm{m}$ ID and $11.2-\mathrm{m}$ length with simplified internals representation. Exit pipe diameter of $150 \mathrm{~mm}$.

\section{Continuing 33}

Parametric tests at LOCA conditions for development of heat transfer correlations.

One subchannel simulation.
35

Hoth BWR and PWR initial fluid conditions to be investigated. 


\section{PRMiliMM}

9. Bottom rloodjug lix jurimituis (li:i:ib, Mild:u, I tolly)

PURPOSP
J'reliminary sxperi--
mentul investipistion
ol colant chinn
themml tran:jient
following bottom
ECC injection.

ECC injection.
10. Dryout Experiments (CISE, Milan, Italy)

11. Cooling of $\mathrm{High}$ Temperature

Surfuces (Ceritral Electricity Generating Board, United Kingdom)

\section{EMERGENCY CORE} COOLANT DELIVERY

1. Semiscale Plexiglass Vessel (USAIC, Aerojet Nuclear Company, NRT'S)

a. Sentiscale Vessel SteridyStato l'ests (UลAlil: nerogret Nustore (Sompury, Ni'l's:

f. $1-1 /:-1,0, p$ tiem incoldo Isothe?"mil I'eshs (USALl, Aerojut Nuc:lear compusy, NI'L'is)
BDHT/CISE Develop a model of local and instantaneous values of flow and quality along fuel channel, compare transient dryout conditions with steady-state conditions.

\section{CeGB}

Obtuin data on the diruct infection of coolant onto the

heated surface for development of physical models.

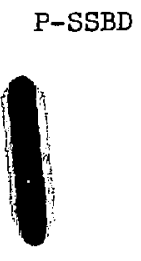

SS-SSBD

$$
\begin{aligned}
& \text { Provide an under- } \\
& \text { standing of ECC } \\
& \text { delivery phenomena, } \\
& \text { irvestigate appli- } \\
& \text { cation of air-water } \\
& \text { countercurrent flow } \\
& \text { correlations to } \\
& \text { downcomer annulus } \\
& \text { geometrles. }
\end{aligned}
$$

Same as for

Semiscale-Flexiglass Vessel with steamwater countercurrent flow and in addition, cficet of heat transfer from flula boundarial at el.cvatei temperutures.

\section{I-SSBD}

Investigate lecc delivery with emphasis on the applicability of steady-state low pressure results to transient blowdown conditions.

\section{EXPERIMENTAL SYSTEM}

Test fucility of directiy heuted tublilar and annular teat elements $4 \mathrm{~m}$ in length.

Externally heated annulus, $--$

1.35-mm ID, 2.1-cm OD and 400-cm length, with initial pressures to 50 bars.

Pin eluster tests with $\varepsilon$ concentric ring of heaters with a central sparge

tube, single rod and tube experiments with water directed at top of heated length, and flat plates experiments with water directed at surface of plate.

Plexiglass test vessel with geometry similar to the 1-1/2-1oop semiscale vessel annulus and downcomer.

12-ft long, 8.5 in.-Iv pressure vessel, 1/2-or $1-$ in. annulus width, outlet phase operator.

Continuing 38

Continuing

Last quarter of 1972

Semiscale vessel; vessel downeomer; operating loop with pump, steam generator, and pressurizer; blowdown loop with simulated steam generator and pump; accumulators. 
JRPOSE

Gnary experi-

investirration

lant cliamos

transient

ing bottom

jection. $p$ a model of and instan3 values of ind quality fruel chanompare ent dryout ions with -state conis.

data on the injection lant onto the

surface for spment of al models.

an under-

$n g$ of ECC

ry phenomena,

igate appli-

h of air-water rcurrent flow

lations to

bmer annulus

tries.

is for

cale-Plexigiass

with steam-

countercurrent

ind In addition,

of heat trans-

on fluia bourid-

at elovateil

ratures.

igate SCC de-

with emphersis

applicability

ady-state low

ire rerults to

lent blowdown

ions.

\section{EXPERIMENTAL SYSTEM}

Test fucility of directly

heuted tubujar and annu-

lar test elements $4 \mathrm{~m}$ in

lenrth.

Externally heated annulus 1.35-mm ID, 2.1-cm OD and 400-cm length, with initial pressures to 50 bars.

Pin cluster iests with a concentric ring of heaters with a central sparge

tube, single rod and tube experiments with water directed at top of heated length, and flat plates experiments with weter directed at surface of plate.

Plexiglass test vessel with geometry similar to the 1-1/2-loop semiscale vessel annulus and downcomer.

12-ft long, 8.5 in.-ID pressure vessel, 1/2-or $1-i n$. ennulus width, outlet phese operater.

Semiscale vessel; vessel downcomer; operating loop with pump, steam generator, and pressurizer; blowdown loop with simulated steam generator and pump; accumulators.
SCHEDULE REF. REMARKS

36 Paraneters varied were pressure, fluw rete, coolant inlet. enthelpy, heating power, and initial wall temperature. Data analyzed to determine influence of cest parameters on temperature turnaround and quenching times.

37 Experimental conditions: steadystate, inlet flow stoppage with pressure transient or power surge.

Continuing 38 Studies on water distribution in a hot cluster and cooling effectiveness of aerosols are in progress.
Continuing

Last quarter of 1972

Mid 1973
Work related to other semiscale testing to understand ECC delivery and bypass. Effects of downcomer length, and lower plenum geometry studied.

Steady-state airwater and steamwater countercurrent flow tests to study effects of water temperature, wall stored energy, downcomer gap width, and lower plenum geometry.

Test conditions include blowdown with and without ECC injection; variation In ECC injection pressure ard location, lower plenum geometry, pump shut- 
lry axperinvestifation at clamnil tran!sient bottom etion.

model of instanralues of quality -I chanpare dryout is with tate con-

ta on the hjection at onto the

irface for int of models. rest rucility of dirertly heuted tubular and annular test elements 4 in in length.
Externally heated annulus, $1.35-\mathrm{mm}$ ID, 2.1-cm OD and 400-cm length, with initial pressures to 50 bars.
Fin cluster tests with a concentric ring of heaters with a central sparge

tube, single rod and tube experiments with water directed at top of heated length, and flat plates experiments with water directed at surface of plate.

Plexiglasi test vessel with geometry similar to the 1-1/2-1oop semiscale vessel annulus and down. comer.

12-ft long, 8.5 in.-IV pressure vessel, 1/2-or 1 -in. annulus width, outlet phase operator.

\author{
Continuing 38 Studies on water \\ distribution in a \\ hot cluster and \\ cooling effective- \\ ness of aerosols \\ are in progress.
}

te licC deth emphasis plicability fstate low results to blowdown
Siemiscale vessel; vessel downcomer; operating loop with pump, steem generator, and pressurizer; blowdown loop with simulated steam generator and pump; accumulators.

\section{Continuing}

Last quarter of 1972

\section{Mid 1973}

Work related to other semiscale testing to understand ECC delivery and bypass. Effects of downcomer length, and lower plenum geometry studied.

Sterdy-state airwater and steam- . water countercurrent flow tests to study effects of water temperature, wall stored energy, downcomer gap width, and lower plenum geometry.

Test conditions include blowdown with and without ECC injection; variation in ECC injection pressure and location, lower plenum geometry, pump shutdown tipnes, and steam Benerator secondary conditions. 
PROGRAM

4. Stersin-Water Mixing l'est

J'renrivin

(U:Alíl. und

Comblastion

Lingineering,

Inc. Windsor,

Connecticut

Reflooding Heat

Transfer

1. Low Rate ECC

Reflooking

Heat Trans-

fer (FIAT

Nuclear En-

ergy Section, Italy)

\begin{tabular}{|c|c|}
\hline $\mathrm{CODH}$ & PURPOSE \\
\hline ( $\mathrm{E} / \mathrm{USAEC}$ & $\begin{array}{l}\text { Invescigate inter- } \\
\text { action of the FCC } \\
\text { fluid with itean } \\
\text { in the primary } \\
\text { system. }\end{array}$ \\
\hline
\end{tabular}

FIAT Obtain rod bundle heat transfer data during seflooding.

Mod-1

Includes investigation of blowdown and ECC injection variables and their influence on cladding temperature.

Siemens/ Investigate the GFM performance of low gressure ECCS and obtain fluid flow and heat transfer data during reflooding.

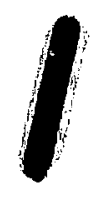

4. Iotis-or-lidid LOPI 'Pest (Usiafic, Aerojet NuloLea1* Company, NRT':i)

\begin{tabular}{l} 
EXPERIMENTAL SYSTEM \\
\hline Stean generator; cold leg \\
with loop seal, simulated \\
punp, and FCC injection \\
nozzle; and reactor ves- \\
sel. Test section is a \\
geometrically scaled mo- \\
del or the piping from \\
the steam senerator to \\
the reactor vessel inlet.
\end{tabular}

Twenty-one heater rod assembly with upper and lower plenum. Heater $O D$ is $9.8 \mathrm{~mm}$, length is $1184 \mathrm{~mm}$, and pitch is $12.9 \mathrm{~mm}$. Uniform power distribution.

A simulated PWR system with generic component elecation, electrically heated core, operating loop, blowdown loop. accumulator, HPIS and LPIS.[a] Capability for 5.5- and 12-foot heated rod lengths.

Preliminary reflooding tests with a single internally cooled tube. Also an electrically heated 340-rod array, 10.75-mm rod diameter, $3 \mathrm{~m}$ in length with chopped cosine power distribution. Bundle has three regions which can be independently heated with maximum power input of $1.4 \mathrm{MW}$. A 16-bar pressure vessel contains the bundle. A bypass simulates the annular downcomer.

$55 \mathrm{MW}(t)$ PWR with en operating loop, a blowdown loop, accumulators, LPIS, JPIS[a], supporting systems, and initially a. 5.5-ft-long core of typical PWT fuel dimensions with about 1300 fuel plns. Cepabj.11ty for a la-ftlong core provided.
SCHEDULE REF.

REV

Continuing 39

Investig hydrauli injectic clinatic section librium various to obtai water ré influenc vessel water

40

Flooding the rang to 0.6 porer vit 0.45 to $\mathrm{kW} / \mathrm{ft}$. ship bet floodine mum acce power we

Emphasi? and 100 effects livery region down.

Continuing 41 Floodin botion simultax and bott

Continuing

Refloodi transfer nuclear: hide ran injectic and inje cations selected 
DSE

e inter-

the ECC

steam

mary
EXPERIMENTAI SYSTEM

Steam enerator; cold leg with loop seal, simulated ymus, and BCC injection nozzle; and reactor vessel. Test section is a geometrically scaled model of the piping from the steam generator to the reactor vessel inlet.

Twenty-one heater rod assembly with upper and lower plenum. Heater $O D$ is $9.8 \mathrm{~mm}$, length is $1184 \mathrm{~mm}$, and pitch is $12.9 \mathrm{rm}$. Uniform power distribution.

investiblowdown ijection and their on claderature.

te the

ce of ure ECCS in fluid heat deta duroding.

ta on yaraulic associated and on mal rering $E C C$ $55 M W(t)$ PWR with an elecation, electrically accumuj.stor, HPIS and

Preliminary reflooding ternally cooled tube. Also an electrically heated 340-rod array, $3 \mathrm{~m}$ in length with chopped cosine power has three regions which can be independently heated with eximum power input 1.4 MW. A 16-bar pressure vessel contains the bundle. A bypass simulates the annular dowacomer.
A simulated PWR system
SCHEDULF

\section{Continuing}

REF.

REMARKS

39

Investigats piping hydraulic resistance, infection nozzle in"clination, test section size. Equilibrium tests at various pressures to obtain data on water remaining, and influence of reactor vessel geometry on water remaining.

40 Flooding rates in the range of 0.2 to $0.6 \mathrm{in} . / \mathrm{sec}$, power veried from 0.45 to 0.65 $\mathrm{kW} / \mathrm{ft}$. A relationship between bottom flooding and maximun acceptable power was obtained.

Emphasizes system and loop component effects on ECC delivery to core region during blowdown.

Continuing 41 Flooding from the bottom only and simultaneous top and bottom flooding.
Continuing operating loop, a blowdown loop, accumulators, LPIS, JPIS [a], supporting systems, and initially a 5.5-ft-long core of typlcal PWT fuel dimerisions with about 1300 ruel pins. Capability for a l2 ftlong core provided. 


\section{PRUGRAM \\ 5. Power Burst \\ Faci 1 i.t.y \\ (USALC, Aero- \\ jet Nuclear \\ Company, NRTS)}

\begin{tabular}{ll} 
CODE & \multicolumn{1}{c}{ PURPOSE } \\
FBF & $\begin{array}{l}\text { Determine maxi- } \\
\text { mun fuel clad- } \\
\text { ding temperature } \\
\text { permitted at the }\end{array}$ \\
& time of coolant de- \\
& livery without loss \\
of cladding inte- & grity, the effect of \\
ballooning on maxi- \\
mum permissible tem- \\
perature, and the \\
effect of degraded \\
coolant performance \\
on the maximum per- \\
missible cladding \\
temperature.
\end{tabular}

Scaled System Effects Experiments

1. I-1/2-Loop Mod-1 (USAEC, Aerojet Nucleer Company, iNRTS)

2. BWR Blowdown Heat Transfer (USAEC and General Electric Company, San Jose, Calif.)

3. Research of Safety Assessment (ROSA), (Japan Atomic Energy Reseurch Instjute 'Tokaj. Laboratury)

h. ruld. Soule iaforty lix perejuctuts or rugibn

\section{Mod-1 Provide LOCA-ECC data; for analy- tical model eval- uetion of total system codes, on effects of phy- sical scale in relation to LOFT scale, and for guidance of LOFT test program.}

GE/BDHT/ Provide informeAEC tion on the transient heat transfer following a rupture of a steam line or recirculation line in a BWR.

ROSA II

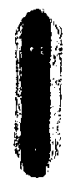

JUGEN
Obtajn information on the effects of system parameters such as piping resistance, power, pressure, break location and size, and ECCS variations, for both BWR and PWR conditions.

Obtain cladding temperature information during blowdown and ECC infection, discharge reaction forces, arid transient charanteristics of the primary system.

\begin{tabular}{l} 
FXPERIMENTAL SYSTEM \\
\hline .... \\
Open tank reactor \\
vessel housing 3- \\
ft-long driver core, \\
a central flux trap \\
region containing an in- \\
pile tube in which the \\
test fuel is located and \\
a loop coolant system for \\
providing required sys- \\
tem conditions in the \\
test section.
\end{tabular}

SCHEDULF REF.

Continuing

vessel housing 3-

A simulated PWR system with an electricelly heated core, an operating loop, a blowdown loop, accumulator, HPIS, and LPIS[a]. Capability for 5.5- and 12-ft-long cores and other sygtem geometry changes.

Scaled BWR systen consisting of a pressure vessel with two external drive pump recirculation loops. Vessel contains $a$ full-size 49-rod electrically heated bundle, two jet pumps, and a steam separator.

ROSA II facility consists of a 265-mm-ID and 5900-mm-long pressure vessel containing 109 electrically heated rods $1500 \mathrm{~mm}$ in length, two loops with pump and steam generators, one of these loops has a rupture unit, pressurizer, and ECCS.

The facility consists of a steum drum, circulating pump, downcomer, lower header, 25 pressure tube ussemblies 3 of which contain electrical.ly heated full-scale fuel assemblies, and ECCS. Fuel agsemblies contain 28 heaters $3.7 \mathrm{~m}$ in length.
Continuing 43

Continuing 42

Continuing 32

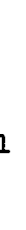




\section{ROSE \\ mexi- \\ clad- \\ perature \\ at the \\ coolant de- ithout loss \\ ing inte- \\ he effect of \\ ing on maxi- \\ issible tem- \\ , and the \\ f degraded \\ performance \\ eximum per- \\ cledding \\ ure.}

LOCA-ECC br analybael evalof total codes, on of phycale ir. $n$ to LOFT and for of LOFT egram.

\section{informa-} the traneat transfer ng a rupture eam line or lation line R.

\section{Information}

effects of parameters piping re-

e, power, fe, break on and size, is variations, in BWh and paltions.

cladding teme information blowdown and ection, Alsreaction and trensiracteristics primaxy sys-

EXPERIMENTAL SYSTEM
Open tank reactor
vessel housing 3-
ft-long driver core,
a central flux trap
region containing an in-
pile tube in which the
test fuel is located and a loop coolant system for providing required system conditions in the test section.
A simulated PWR system with an electrically heated core, an operating loop, a blowdown loop, accumulator, HPIS, and LPIS[a]. Capability for 5.5- and 12-ft-long cores and other system geometry chenges.

Scaled BWR system consisting of a pressure vessel with two external drive pump recirculation loops. Vessel contains $a$. full-size 49-rod electrically heated bundle, two jet pumps, and a steam separator.

ROSA II facility consists of a $265-\mathrm{mm}-I D$ and 5900-mm-long pressure vessel containing 109 electrically heated rods $1500 \mathrm{~mm}$ in length, two loops with pump and steam generators, one of these loops has a rupture unit, pressurizer, and ECCS.

The facility consists of a. steam drum, circulating punp, downcomer, lower header, 25 pressure tube ussemblies 3 of which contain electrically heated full-scale fuel assemblies, and ECCS. Fuel assemblies contain 28 heaters $3.7 \mathrm{~m}$ in length.

\begin{tabular}{|c|c|c|}
\hline SCHEIULLE & REF. & REMARKS \\
\hline Continuing & & $\begin{array}{l}\text { Tests with both PWh } \\
\text { and BWR fuel cluster; } \\
\text { up to } 24-p i n \text { array. } \\
\text { Top spray or bottorn }\end{array}$ \\
\hline
\end{tabular}

flooding capability. Tests include use of irradiated fuel.
Continuing 42 Testing conditions to include: variation of: initial system conditions, break size and locations, and power decay transient.

Continuing 32 ROSA II facility is belng fabricated. Testing is scheduled to begin in October 1973.
Continuing 43 Experimentel facility is a mockup of the prototype, heavywater-moderated, bolling-light-watercooled reactor, FUGEN.

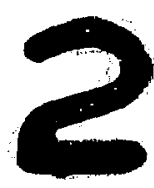




\begin{tabular}{l} 
PROGRAM \\
\hline 5. Full Length \\
Emergency \\
Cooling Heat \\
Transfer- \\
System Ef- \\
fects l'ests \\
(USAEC and \\
Westinghouse \\
Electric \\
Corporation, \\
Pittsburgh, \\
Pa.)
\end{tabular}

Large-Systen Effects Experiments with Nuclear Heat Source
1. Loss-of-Fluid LOPT Test (USAEC, Aerojet Nuc- lear Company, NRTS)

\begin{tabular}{|c|c|}
\hline CODE & PURPOSE \\
\hline $\begin{array}{l}\text { FLECHT- } \\
\text { SET }\end{array}$ & $\begin{array}{l}\text { Provide experimental } \\
\text { data on the influ- } \\
\text { ence of systen er- } \\
\text { fects on tcc behuvion } \\
\text { during reflocilnk. }\end{array}$ \\
\hline
\end{tabular}

\begin{abstract}
EXPERIMENTAL SYSTEM
FLECHT flow housing and $a$ power profiled. $10 \times 10$ heater rod test assembly, coolant supply system, downcomer, pressure control system, upper and lower test section plenums, and single loop consisting of piping, valves, and orifices. In later tests the single loop will be replaced by two loops each having a full length steam generator, pump simulator, and piping arranged to represent elevations and flow characteristics in the loops.
\end{abstract}

$55 \mathrm{MW}(t)$ PWR with an operating loop, a blowdown loop, accumulators, LPIS, HPIS[a], aupporting systems, and inftielly a. 5.5mft-long core otherwise of typical PWR fuel dimensions with about 1300 fuel pins. Capability for a 12-ft-long core provided.

\section{SCHEDULE REF.}

29

Test

influ chara flood: relea ding carry sure syste testil consi

\section{Cont Inuing}

Test vide mente at $1 \mathrm{a}$ more sion react gener of $n v$ inter: clada chang: ditic coola metry tempe conat minin emerg ing $\mathrm{p}$

[a] MPIS -- high pressure injection system; LPIS -- low pressure injection system.

Table 111 is inlended to show the relation of the various research programs throughout the world to tho previously presented fault tree which are enclosed hy diamond symbols. The table is arranged starting with Firand trec in which, for example, information nerds in the blowdown heat transfer area are exhibited. For each even diamond. a list of "subevent effects" is developed which indicates specific technical problems which must bu resolved. 'Thesc problems are in turn related to a codr symbol of the various research programs identified in Tab tables is intended more to be illustrative of the manner in which the total research and development is applied to th rather than to be a comprehensive or exhaustive treatment identifying deficiencies of areas not addressed developmint efforts. 


\begin{tabular}{|c|c|c|c|}
\hline EXPERIMENTAL SYSTEM & SCHEDULE & REF. & REMARKS \\
\hline $\begin{array}{l}\text { CHT flow holsing and a } \\
\text { er profiled } 10 \mathrm{x} 10 \\
\text { ter rod test assembly, } \\
\text { lant supply system, } \\
\text { ncomer, pressure con- } \\
\text { I system, upper and } \\
\text { er test section ple- } \\
\text { s, and single loop } \\
\text { sisting of plping, } \\
\text { ves, and orifices. } \\
\text { later tests the single } \\
\text { will be replaced } \\
\text { two loops each having } \\
\text { ull length steam gen- } \\
\text { tor, pump simulator, } \\
\text { piping arrenged to } \\
\text { resent elevations and } \\
\text { characterlstics in } \\
\text { loops. }\end{array}$ & End 1973 & 29 & $\begin{array}{l}\text { Test emphasize the } \\
\text { influence of system } \\
\text { characteristics on } \\
\text { flooding rate, heat } \\
\text { release from clad- } \\
\text { ding and flow housing, } \\
\text { carryover, and pres- } \\
\text { sure drop. Additional } \\
\text { system features and } \\
\text { testing are belng } \\
\text { considered. }\end{array}$ \\
\hline $\begin{array}{l}\text { WW(t) PWR w1th an } \\
\text { cating loop, a blow- } \\
\text { loop, accumulators, } \\
\text {, HPIS[a], aupporting } \\
\text { cems, and inftiolly } \\
\text { 5-ft-long core other- } \\
\text { of typical PWR fuel } \\
\text { onglons with about } \\
\text { fuel plns. Capab1lity } \\
\text { a l2-ft-long core } \\
\text { rided. }\end{array}$ & Continuing & & $\begin{array}{l}\text { Test data will pro- } \\
\text { vide unique experi- } \\
\text { mental information; } \\
\text { at large scale, in } \\
\text { more than one dimen- } \\
\text { sion within core and } \\
\text { reactor vessel, with } \\
\text { generic time constants } \\
\text { of nuclear fuel, with } \\
\text { interacting effects of } \\
\text { cladding ballooning, } \\
\text { changing fuel gap con- } \\
\text { ditions and changing } \\
\text { coolant channel geo- } \\
\text { metry, and at high } \\
\text { temperature fuel } \\
\text { conditions for deter- } \\
\text { mintng margins of } \\
\text { emergency core cool- } \\
\text { ing performance. }\end{array}$ \\
\hline
\end{tabular}

pressure injection system.

pus researeh programs throughout the world to those events in the: d symbols. The table is arranged starting with Branch 1 of the fault wn heat transfer area are exhibited. For each event identified as a dicates specific technical problems which must be considered or of the various research programs identified in Table II. This set of $h$ the total research and development is applied to the problem areas identifying deficiencies of areas not addressed by rescarch and

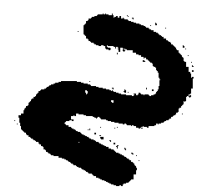


BRANCH 1 -- Analysis Overpredicts Energy Removal Rates Or Underpredicts Stored Energy $\rightarrow$

BRANCH EVENTS
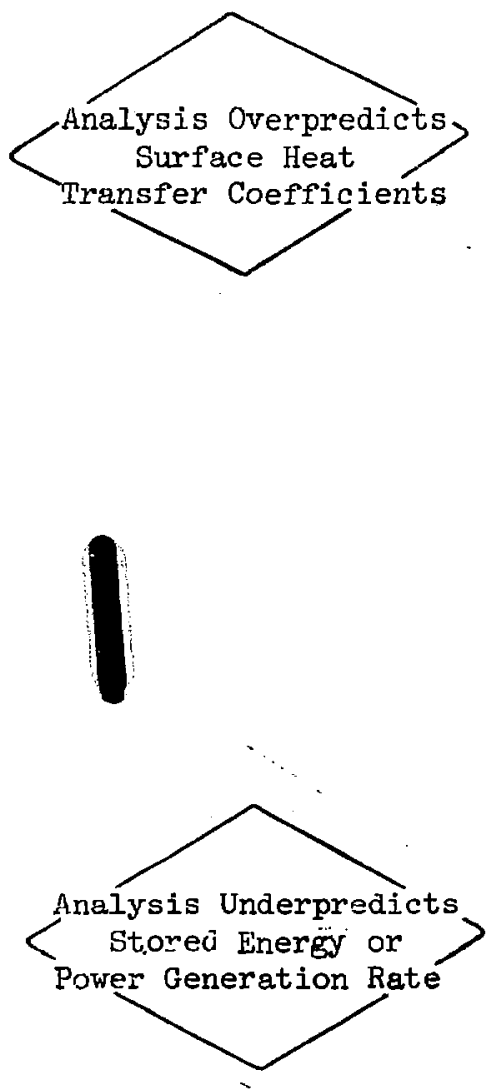

SUBEVENT EFFECTS TO BE CONSIDERED

- Gap conductance during blowdown with nuclear fuel

- Conditions to initiate CHF

- Conditions to rewet and restore preCHF cooling

- Conditions for transition boiling heat transfer

- Conditions for film boiling heat transfer

- Radial coolant flow in core
POTENTIALLY

$\mathrm{R}$ AND D PR

PBF, LOF'T

In one dimen

UCIN/AEC ORNL/BDHT ROSA

GE/BDHT/AE

Mod-1

GE/DC/AEC AEG/GFM

ISPRA

BDHT/CISE

CEGB

In more than mension:

FUGEN

LOFT

PBF

LOFT
- Operating gap conductance

- Axial location of peak power

- Magnitude of peak power

- Power decline rate

- Decay heat rate

- Metal-water reaction energy

- Fuel densification

BRANCH 2 -- Analysis Underpredicts Time To Initiate Reflooding.
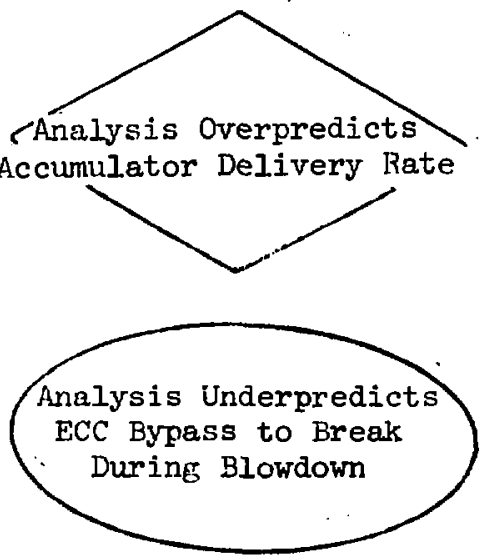

- Broken pipes

- Stuck check valves

- Line restrictions

- Low gas pressure

- Low whter Inventiory

- ECC entrainment to break

- Steam condensation and pressure drop in cold leg piping
Design - HHS Quality Assu Technical. $\mathrm{Sp}$. tion, and $\mathrm{Co}$ ancel $b$ ]

CE/AEC, SSB Mod-1, LOFT, counter-current blowdown flow 
Removal Rates Or Underpredicts Stored Energy

SUBEVENT EFFECTS TO BE CONSIDERED

fap conductance during blowdown with huclear fuel

Conditions to initiate CHF

Conditions to rewet and restore preCHF cooling

conaitions for transition boiling heat transfer

Conditions for film boiling heat transfer

Radial coolant flow in core
POTENTIALLY APPLICABLE $R$ AND D PROGRAMS

PBF, LOF'?

In one dimension:

UCIN/AEC

ORNL/BDHT

RGSA

GE/BDHT/AEC

Mod-1

GE/DC/AEC

AEG/GFM

ISPRA

BDHT/CISE

CEGB

In more than one dimension:

FUGEN

LOFT

PBF

LOFT

Decay heat rate

Metal-water reaction energy

Fuel densification

te To Initiate Reflooding.

Droken pipes

Stuck check valves

Line restrictions

Low gas pressure

Iow writer Inventory

ECC entrainment to break

Steam condensation and pressure

drop in colc leg piping

Downcomer penetration of ECC with counter-current blowdown flow
Design - HHST[ $[\mathrm{a}]$

Quality Assurance,

Technical Speciflcation, and Cornpliance $[b]$

CE/AEC, SSBD, ROSA II, Mod-1, LOFT 


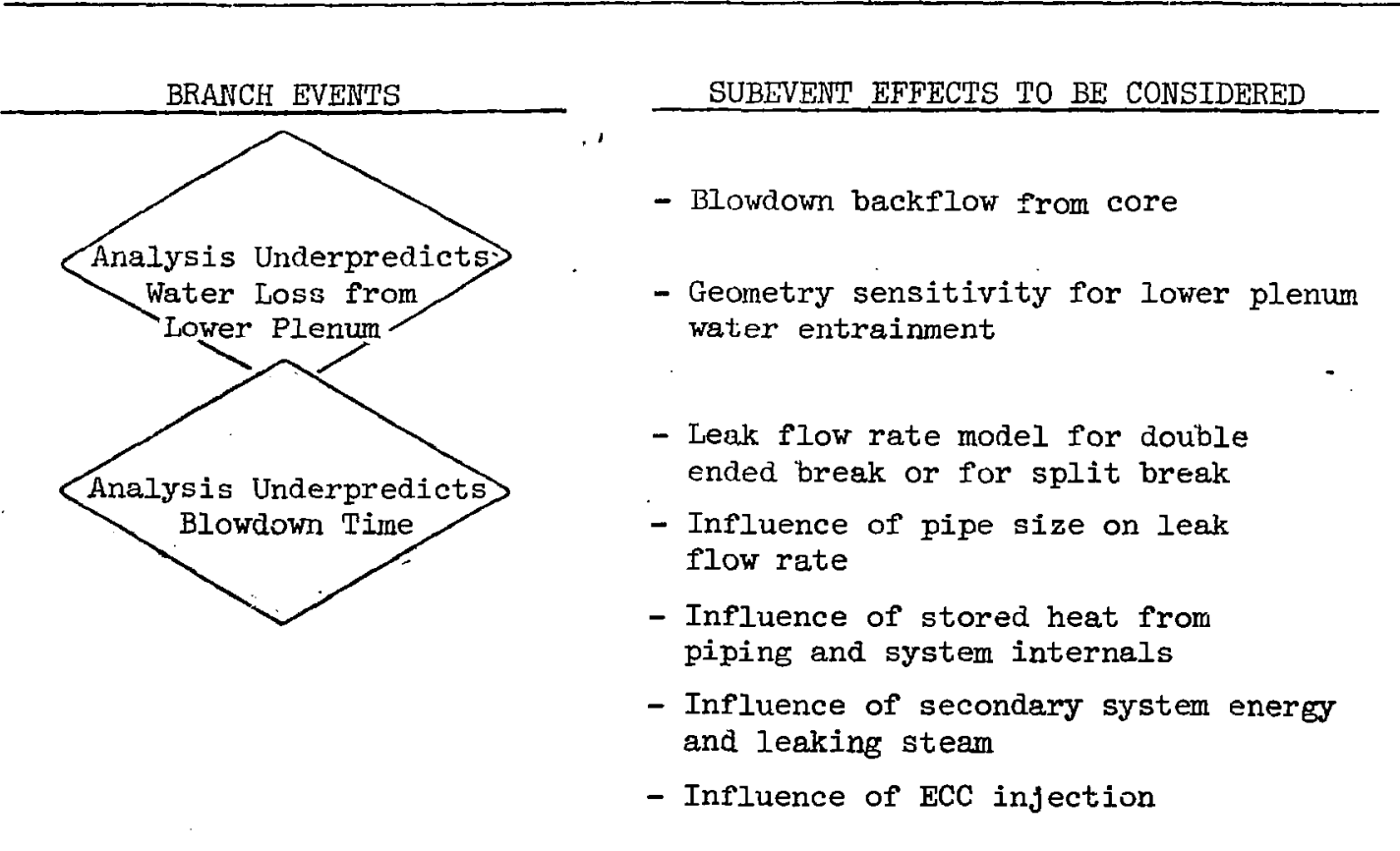

BRANCH 3 -- Analysis Underpredicts Core Temperature At Time of Reflooding Initiation.

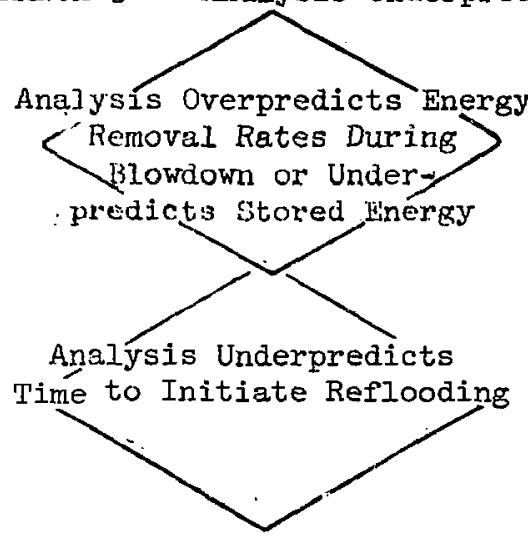

This event is in essence low blowdown heat transfer which is developed in Branch 1 .

This event and its subevents are identical to Branch 2.

BliANCll 4 -- Mnalysis Underpredicts Power Generation During Core Reflooding.
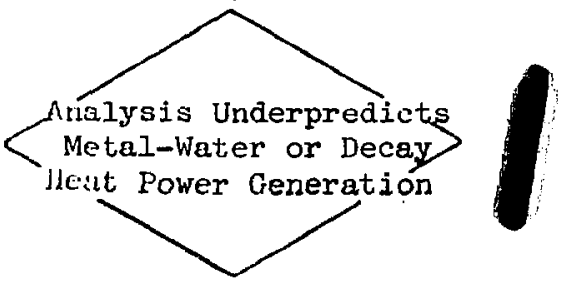

This event is caused by subevents identical to those of the second event developed for Branch 1.

RRANCH 5 -- Analysis Overpredicts Energy Removal Rates During Core Reflooding

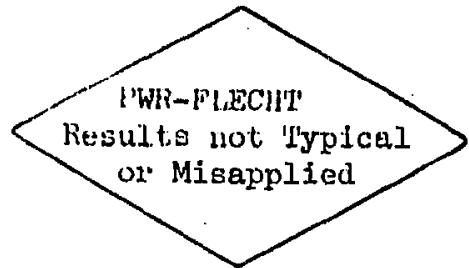

- One dimensionality

- Axial power profile noncosine

- Zircaloy versus stainless steel

- Experimentel errors

- Limited system representation

FLECHT-SET

ROSA II

I'TAT

Mod-1

Siemens/GF: LOFT 
Blowdown backflow from core

\} SSBD, ROSA, Mod-1,

Geometry sensitivity for lower plenum water entrainment

I SSBD, Mod-1

Leak flow rate model for double ended break or for split break

) SSBD, UKAEA, ROSA, 3 BMI/GFM, MOd-I, LOFT

Influence of pipe size on leak flow rate

\} UKAEA, FUGEN, LOFT

\} SSBD, Mod-1, LOFT

piping and system internals

- Influence of secondary system energy and leaking steam

- Influence of ECC infection
\} SSBD, MOd-1, LOFW

\} SSBD, ROSA, Mod-1, LOFT

iore Temperature At Time of Reflooding Initiation.

This event is in essence low blowdown heat transfer which is developed in Branch 1.

This event and its subevents are identical to Branch 2.

'ower Generation During Core Reflooding.

This event is caused by subevents identical to those of the second event developed for Branch 1 .

ergy Removel Rates During Core Ref Looding

- One dimensionality

- Axial power profile noncosine

- Zircaloy versus stalriless steel

- Experimental errors

- Limited system representation
FLECHT-SET

ROSA II

FTAT

Mod-1

Siemens/GFB

LOFT 


\section{BRANCH EVENTS}
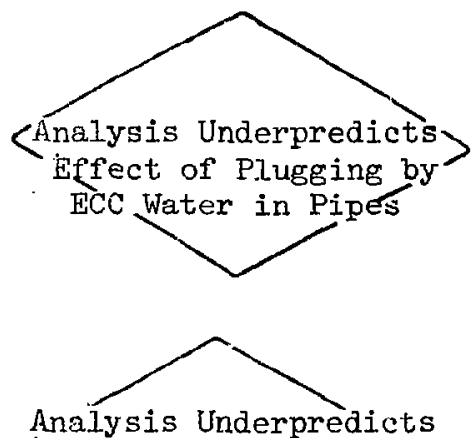

Iínergy or Nass Iransfer.

from Steam Generator

Secondary systsm to

Primary, Loop
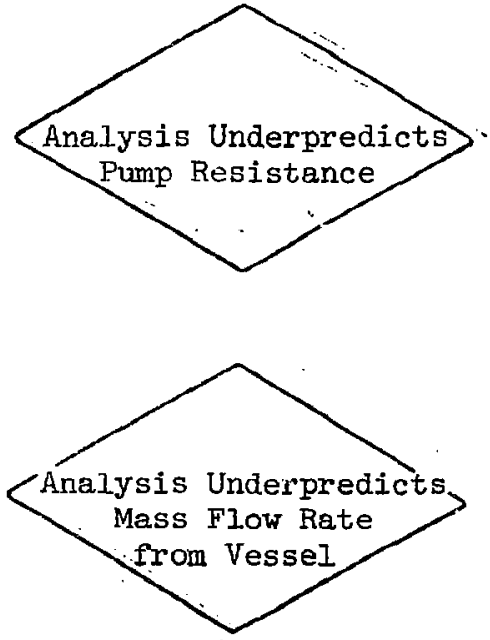

\section{SUBEVENT EFFECTS TO BE CONSIDERED}

POTENTIAI

$\mathrm{R}$ AND

- Momentum exchange between system steam.and injected ECC.

- Geometry of injection configuration

- Flow regime downstream of injection location

- Secondary system fluid conditions

- Heat trunsfer characterization acrows steam generator tubes

- Acceleration-pressure-drop due to compressible flow

- Steam leakage from secondary system

- Two-phase pressure drop for driven, coasting and stalled large scale pumps

- Compressibility effects

- Density of steam leaving the steam generator

- Liquid mass fraction carried from upper plenum into steam generator

- Division of coolant mass leaving core and entering unbroken loops and broken loops

- Steam flow distribution and entrainment of ECC in inlet pipes and in upper core barrel annulus
Small Sc Mod-1 ROSA

Large $\mathrm{Sc}$ LOFT

SSBD

Mod-1 ROSA IIIr CE/USAE! FLECHT$\mathrm{L}, \mathrm{OFT}$

[a] Heavy Section Steel Technolcgy Program, ORNL/USAEC.

[b] Not $R$ and $D$-- edded for completeness.

The description of the experiments refercneed in the two tables, when viewed in light of the current stat teehniefues, reveals the following:

(1) A proul dial of research and developmeml has been and is continuing to he ardressed to berch at

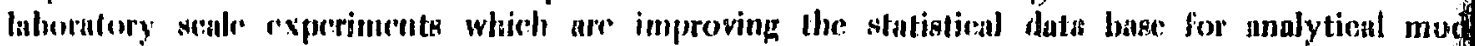

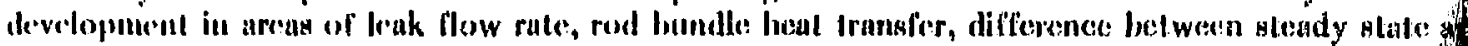
transient leat transfer, and two-phase pressure drops. 'I'he various experiments are being conducted several countries.

(2) A considerable number of system effects experiments are to become operational within the next yo The difficulty in applying data from any system effects test at less than full size is the understanding the scaling inethods uscd. Although significant differenees exist in the sealing of similar experimien 
- Momentum exchange between system steam and injected ECC

- Geometry of injection configuration

- Flow regime downstream of injection location

- Secondary system fluid conditions

- Heat trunsfer characterization across steam generator tubes

- Acceleration-pressure-drop due to compressible flow

- Steam Ieakage from secondary system

- Mwo-phase pressure drop for driven, coasting and stalled large scale pumps

- Compressibjlity effects

- Density of steam leaving the steam generator

- Liquid mass fraction carried from upper plenum into steam generator.

- Division of coolant mass leaving core and entering unbroken loops and broken loops

- Steam flow distribution and entrainment of ECC in inlet pipes and in upper core barrel annulus

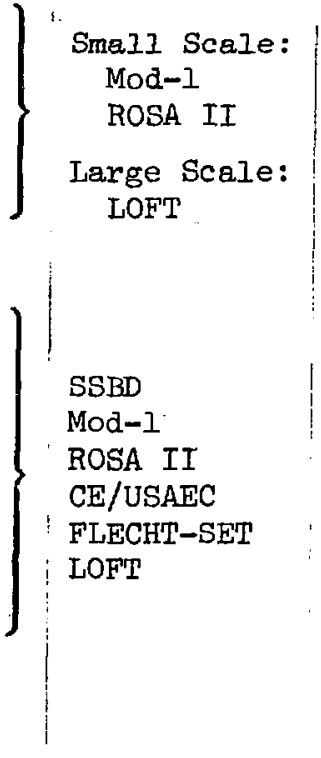

Iogy Program, ORNL/USAEC.

Mod-1

ROSA II

LOFT

CE/USAEC

Mod-I

completeness.

ats refereneed in the two tables, when viewed in light of the current state of the analysis

and dovelopumenl lass becen and is continuing to be addressed to bench and Guts which ane improving the statistimal data base for analytical model k flow rate, rod lomille leal Iransfor, difference hetween steady statc and two-phase: pressure drops. The various experiments are being conducted in 
through adequate mrasurements, the data from systems effects experiments could still provid significant increase in the data base for testing the capability of system codes. Unfortunately, with exception of the LOFT tests, and possibly the FUGEN tests ${ }^{43}$ in Japan, the various system effe configurations are small in scale compared to large power reactors and dominantly one-dimensionas, the reactor core and vessel representation.

(3) The various research and development programs promise to provide a wealth of information blowdown fluid behavior, blowdown heat transfer, and reflooding heat transfer. Little attent: outside the U.S. and Japan, however, is being directed to the question of ECC delivery during llowdown process. Scoping information is needed in this area in order to guide the analyt development and determine whether the effeets of interaction between the ECC delivery blowdown processes can contribute to both loss of the ECC inventory as it is delivered and extens of the blowdown time.

\section{CONCLUUSIONS}

The "fault tree" method has heen used to identify and evaluate the sensitivity of potential analysitcal fau of performance requirements for a PWR emergeney core cooling system. From the example case studied the foll the predieted energy removal rates prior to FCC action are significantly lower than actual values, the majority identified on the tree will be unimportant. However, if predicted energy removal rates are higher than act cladding temperature limits are approached before the lower plenum is refilled, then the subtle errors in the an? duration, "steam binding", friction pressure drop, application of flooding heat transfer data, and decay heat rates could have significant influence on ECC performance requirements.

The performance maps and discussion presented have shown for the PWR case that the cladding tem initiation of flooding is primarily influenced by the variables of flooding rate, initial decay heat power level, i metal-water reaction, rate, and initial zirconium oxide: thickness. For the BWR case, the influence of the thick: change in location of the lot spot from a corner position to a central position in the fuel assembly during accident permits cladding temperatures considerably in excess of $2300^{\circ}$ before a $40 \%$ embrittlement is reached.

The researeh and development programs throughout the world are addressing many aspects of the all imp blowdown heat transfer, and ECC heat transfer question. System effects tests addressing the ECC delivery and Jower plenum refill are limited to a few prograins in the U.S. and Japan.

linproved precision in and verification of the calculational techniques used for predicting blowdown blowdown duration are expected to reveal conservatisms in quantifying the margins of ECC performance. $C$ required in the analysis and verification of emergency core cooling delivery and lower plenum refill in ord potential margins of ECC system design. 
data from systems effects experiments could still provide a or tesling the capability of system codes. Unfortunately, with the ossibly the FUGEN tests ${ }^{43}$ in Japan, the various system effects pared to large power reactors and dominantly one-dimensional in ion.

ent programs promise to provide a wealth of information on in heat transfer, and reflooding heat transfer. Little attention , is being directed to the question of ECC delivery during the pation is nceded in this area in order to guide the analysis ler the effects of interaction between the ECC delivery and to both loss of the ECC inventory as it is delivered and extension

\section{CONCLUSIONS}

identify and evaluate the sensitivity of potential analysitcal faults in the selcolion ncy core cooling system. From the example case studied the following are ciled. If action are significantly lower than actual values, the majority of the faul $i$ states owever, if predicted energy removal rates are higher than actual values so that pre the lower plenum is refilled, then the subtle errors in the analysis of blowdown op, application of flooding heat transfer data, and decay heat power generation formance requirements.

esented have shown for the PWR case that the cladding temperature rise after the variables of flooding rate, initial decay heat power level, initial temperature, oxide thickness. For the BWR case, the influence of the thicker cladding and the ner position to a central position in the fuel assembly during the course of the hbly in excess of $2300^{\circ}$ before a $40 \%$ embrittlement is reached.

throughout the world are addressing many aspects of the all important blowdown, question. System effects tests addressing the ECC delivery and potential delay in $\mathrm{s}$ in the U.S. and Japan.

of the calculational techniques used for predicting blowdown heat transfer and nservatisns in quantifying the margins of ECC performance. Completeness is yet lergency core cooling delivery and lower plenum refill in order to quantify the

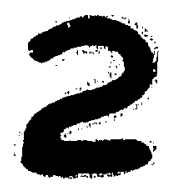


1. N. F. CLASSON, Pre-Accident Investigalion, Goddard Space Center Flight Cenler, Grexnloclt, Mary NASA Syslem Salcty Confereneo (May I-3, 1968).

2. G. B. WAILIS, One-Dimensional Two-Phase Flow, Me(iraw-Ilill, Ine. (I969).

3. F. I. MOOI)Y, Maximum Flow Rate of a Single Component, Two.Phase Mixture, Trans. ASME, Jou 1965. pp 134.142.

4. L. BAKER, Jr. and L. C. JUST, Studies of Metal-Water Reactions at High Temperatures, ANL-6548 (M

5. F. F. CADEK, D. P. DOMINICIS, and R. H. LEYSE, PWR-FLECHT (Full Length Emergency Coolin R(port, WCAP-7665 (April 197I).

6. J. D. IOUNCAN and J. E. I.EONARD, Emergency Cooling in BWR's Under Simulaled Lass(1BWR-FI,ECIIT Final Report) GEAP-13197 (June 197I).

7. R. H. MFSERVEY and R. HERZEL, Brittle Behavior of Zircaloy in an Emergency Core Cooling (September 1970).

8. J. C. HESSON, et al, Laboralory Sinulations of Cladding - Steam Reactions lollowing Loss-of Water-Cooled Power Reactors, ANL-7609 (Jamuary 1970).

9. G. J. SCATENA, Fuel Claddiug Embrittlement During a Loss-of-Coolant Aecident, NliDO-10674 (Octo

10. R. J. WAGNER, HEAT-I - A One-Dimensional Time Dependent or Steady-State Heat Conduction C 1963).

11. Y. S. TOULOUKIAN(ed.), Thermophysical Properties of High Temperature - Solid Materials - Volun York: The MacMillan Company (1967).

12. R. W. GRIEBE, An Analysis Tcchnique for Top Spray Cooling of a Boiling Water Reactor, AICh presented at the 13th National Heat Transfer Conference, Denver, Colorado, August 6-9, 1972.

13. D. R. EVANS, MOXY: A Digital Computer Code for Core Heat Transfer Analysis, IN-1392 (August 197

14. D. R. EVANS, Sensitivity Studies of BWR Core Thermal Response to LOCA Using MOXY Code, AIC presented at the 13th National Heat Transfer Conference, Denver, Colorado, August 6-9, 1972.

15. L. J. YBARRONDO, C. W. SOJBRIG and H. S. 1SBIN, The Calculated Loss-of-Coolant Aeridsut - A presented at the December 1971 AIChE Meeting, San Francisco, California.

16. Babeock \& Wilcox Company, CRAFT - Jeseription of Model for Equilibrium LOCA Analysis Program 1971).

17. Westinghouse Electric Corporation, A Comprehensive Space-Time Dependent Analysis of Loss-of-Coo Code), WCAP-7750 (August 1971).

18. S. FABI(, Deseription of the HI,OUWN-2 Compuler Cude, WCAP-7593, Oetober 1970 (proprietary).

19. I1. AIBSL-I.AISLEN und JPNS ANDFRSEN, Blowdown and Core lleatup Computer Codes, paper

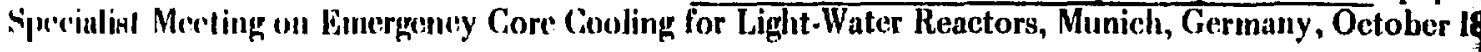

20. $\Lambda$ MACNI, 'TII'T': A Digital Simulation Program for the Study of Hydrodynamic Proecsses and Cor Water Preskure 'lube Roaclor During Trunsient Conditions, paper presented at CREST Specialist Meetin Cooling for liggli Water-Rractors, Munich, Germany, Oetober 18-20, 1972.

21. W. II. R.El"IIG, ct al., RELAPB - A Computer Progrum for Reactor Blowdown Analysis, IN-132l (June 
stigation, Goddard Space Center Flight Center, Greconbelt, Maryland, presented al the 9y $1-3,1968)$.

D-Phase Fluw, Mr:(Sraw-1lill, lnc: (1969).

of a Single Component, Two-Phase Mixture, Trans. ASME, Journal of Heat Transier, es of Metal-Water Reactions at High Temperatures, ANL-6548 (May 1962).

ad R. H. LEYSE, PWR-FLECHT (Full Length Emergency Cooling Heat Transfer) Final

ARD, Emergency Cooling in BWR's Under Simulated Loss-of-Coolant Conditions 13197 (Juine 197i).

L, Brittle Behavior of Zircaloy in an Emergency Core Cooling Environment, IN-I3839

Simulations of Cladding - Steam Reactions Following Loss-of-Coolant Aceidents in 609 (January 1970).

ittlement During a Loss-of-Coolant Accident, NEDO-10674 (Oetober 1972).

mensional Time Dependent or Steady-State Heat Conduction Code, IJ)O-I6867 (April ysical Properties of High Temperature. Solid Materials - Volume I, 2-I, and 4-I, Ni:w

ique for Top Spray Cooling of a Boiling Water Reantor, AIChE Paper (Preprint 30), ransfer Conference, Denver, Colorado, August 6-9, 1972.

gputer Code for Core Heat Transfer Analysis, IN-1392 (August 1970).

BWR Core Thermal Response to LOSA Using MOXY Code, AIChE Paper (Preprint 31), ransfer Conference, Denver, Colorado, August 6-9, 1972.

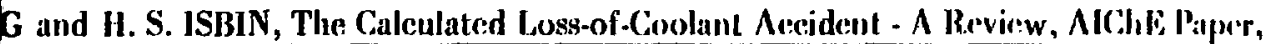
Meeting, San Franciseo, California.

- Description of Model for Equilibrium LOCA Analysis Program, BAW-10030 (Octolorer

Comprehensive Space-Time Dependent Analysis of Loss-of-Coolant (SATAN-4 Digital

N-2 Computer Code, WCAP-7593, October 1970 (proprietary).

ERSEN, Blowdown and Core Healup Compuler Codes, paper presented at CREST Couling for Light-Water Reactors, Munich, Germany, October 18-20, 1972.

oul Program lor the Study of Hydrodynamir Processes and Core Heatup of a Boiling - Funsient Conditions, paper presented at CREST Speciulist Meeting on Emergency Core ech, Germany, Ocloher 18-20, 1972. 


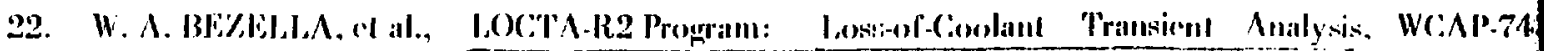
(propriclary).

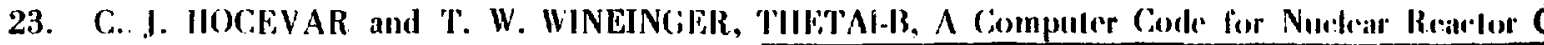
IN-1445 (Fobruary 1971).

24. D. S. ROWE, COBRA-III: A Digital Computer Program for Steady-State and Trásicnt Thermal-Hy Bundle Nuclear Fuel Elements, BNWL-B-82(1971).

25. R. W. BOWRING, HAMBO. A Computer Programme for the Subehannel Analysis of the $H$ Characterislics of Rod Clusters, Part l, General Description, AEEW-R524, Great Britain, (1967).

26. T. E. CURRY, Scmistale Projeel Test Data Report - Test 85I, ANCR-1065 (June 1972).

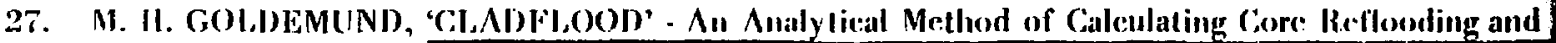

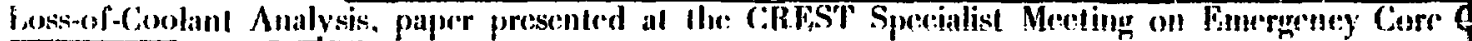
Reactors, Munich, Germany, Oclober 18-20, 1972.

28. Balscock \& Wileox Company, RFFLOOD - Deseription of Model for Multinode Core Reflood Analys 1971).

29. F. F. CADEK, J. A. BLAISDELI, and A. P. SUDA, PWR-FLECHT System Effects T'ests Program 1972).

30. L. T. LAKEY, et al., Deficient Cooling Eighth Quarterly Progress Report April I - June 30, 197l, GEAI

31. Personal eommunieation between J. A. DEARIEN, Aerojet Nuclear Company and A. R. EDWA Atomic Energy Authority, Risley, England (February 1971).

32. H. SHIMAMUNE, et al., Current Status of ROSA Program, paper presented at CREST Specialist Meet Cooling for Light-Water Reactors, Munich, Germany, Octoter 18-20, 1972.

33. E. HICKEN, E. KOCH and O. SCHAD, Heat Transfer During Blowdown with an Inside Cooled Tub presented at CREST Specialist Meeting on Emergency Core Cooling for Light-Water Reattors, Mun; 18-20, 1972.

34. I. FRIZ and R. RIFBOLD, Experimental Investigation of the Post-Crisis Heat Transfer in a Coolin During Depressurization, paper presented at CREST Specialist Meeling on Emergency Core $G$ Reactors, Munich, Germany, October 18-20, 1972.

35. B. RUDICER, Experimental Blowdown Studies of a Reactor Simulator Vessel Containing Simp presented at CREST Specialist Meeting on Emergency Core Cooling for Light-Water Reactors, Muni 18-20, 1972.

36. R. MARTINI and A. PREMOLI, Bottom Flooding with Simple Geometrics Under Different E presented at CRES'T Specialist Meeting on Emergency Core Cooling for Light-Water Reactors, Muni $18-20,1972$.

37. G. P. GASPARI, et al., Dryout Onset in Flow Stoppage Depressurization and Power Surge Transien C.RFST Specialist Meeting on Emergency Core Cooling for Light-Water Reactors, Munich, Germany, $\mathbf{0}$

38. R. B. DUFFY and D. PORTHOUSE, Experiments on the Cooling of High-Temperature Surfaces by palper presented at CREST Spccialist Meeting on Emergency Core Cooling for Light-Water Reacto Oclober 18-20, 1972.

39. P. A. LOWE and W. E. BURCHILL, Steam-Water Mixing Test Program Task D: Informal Report T CENPD-62, (October 1972).

40. A. CAMPANILE and G. P. POZZI, Low Rate Emergency Reflooding Heat Transfer Tests in Rod Bur CREST Specialist Meeting on Eınergeney Core Cooling for Light-Water Reactors, Munich, Germany, 0 


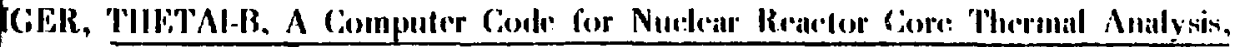

omputer Program for Steady-State and Transicnt Thermal-Hydraulic Analysis of Rod B-82(1971).

puter Programme for the Subchannel Analysis of the Hydraulic and Burnout General Deseription, AEEW-R524, Great Britain, (1967).

ata Report - Test 85], ANCK-I065 (June 1972).

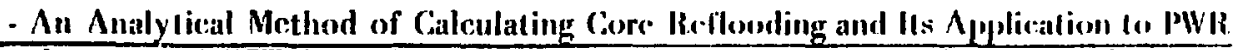

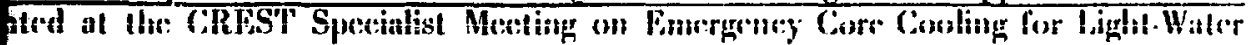
$3-20,1972$.

DD - Dreseription of Model for Multinode Core: Reflood Analysis, BAW-10031 (0) Lolorer

A. P. SUDA, PWR-FLECHT System Effects Tests Program Plan, WCAP-7906 (April

Eighth Quarterly Progress Report April I - June 30, 1971, GEAP-10221-8 (Junc 1971).

A. DEARIEN, Aerojet Nuclear Company and A. R. EDWARDS, United Kingdom and (February 1971).

of ROSA Program, paper presented at CREST Specialist Meeting on Emergency Core ch, Germany, October 18-20, 1972.

- Heat Transfer During Blowdown with an Inside Cooled Tube as Test Section, paper on Emergency Core Cooling for Light-Water Reactors, Munich, Germany, October

htal Investigation of the Post-Crisis Heal Transfer in a Cooling Subehamnel of a PWIR nted at CREST Specialist Meeting on Emergency Core Cooling for Light-Waler p-20, 1972.

wn Studies of a Reactor Simulator Vessel Containing Simplificd Internals, paper on Emergency Core Cooling for Light-Water Reactors, Munich, Germany, October

ttom Flooding with Simple Geometrics Under Different ECC Conditions, paper on Emergency Core Cooling for Light-Water Reactors, Munich, Germany, October

in Flow Stoppage Depressurization and Power Surge Transients, paper presented at y Corc Cooling for Light-Water Reactors, Munich, Germany, October 18.20, 1972.

ixperiments on the Cooling of High-Temperature Surfaces by Water Jets and Brops, Meeting on Emergency Core Cooling for Jighi-Water Reaetors, Munich, Grermany,

team-Water Mixing Test Program Task D: Informal Report T'est Matrix for T'ask C, 
41. K. RIISI)I.E and F. WINKLER, FCC.Rel7ooding Fixperiments with a 340-Rod Bundle, paper presented at CA Nerting on Simergeney Core Cooling for !ight-Waler Reatotor, Munich, Germany, Oclober 18-20, 1972.

42. G. W. BUIRNETT, D. W. DANIELSON, and K. A. NIISSON, Blowdown Ileal Transfier Program Task C-I I Preliminary System Design Deseription of Two-toop Test Apparatus, GEAP-13276, (March 1972).

43. M. TOKLIMITSU, Full-Scale Safely Experimmls of FUGEN, paper presented al the CREST Special Emergeney Core Cooling for lidint-Water Reactors, Munich, Germany, October 18-20, 1972. 
fiooding Experiments with a 340-Rod Bundfe, paper presented it C:REST Sprecialist I.ight-Water Reactors, Munich, Germany, Octobor 18-20, 1972.

and K. A. NIISSON, Blowdown Heal Transfer Program 'Task (i-l Inlormal Rupourt if Two-Loop Test Apparatus, GFAP.13276, (March 1972).

Jxperiments of FUGEN, paper presented al the CREST Specialist Mesting on Reactors, Munich, Germany, Octobor 18-20, 1972. 


\section{FMERGENCY CORE COOIING SYSTEM DESIGN CONCEPTS FOR CONTEMPORARY PWR's AND}

The treal ment of the design of emergency coolant supply systems is described for those plants of current designs. The description for PVR designs characterizes the generic fealures which typify the plants of several manuf

\section{PWR ECC DESIGNS}

A sehemalie: representation of two loops of a multiple loop U.S. PWR is shown in rough seale in Figure A-1; configuralion has all primary system componconts and all inlet and outlet pipes to the reactor vessel above the top o arrangement is intended to assire an enclosure arourd the reactor core that has no penetrations and thus has a hi auxiliary refill coolint to cover the core for all possible pipe breaks in the primary coolant circuit. The PWR ECC with injection into the inlet pipes or the upper regions of the inlet annulus, depending on the manufaclurer, a flooding the reactor vessel from the core bottom.
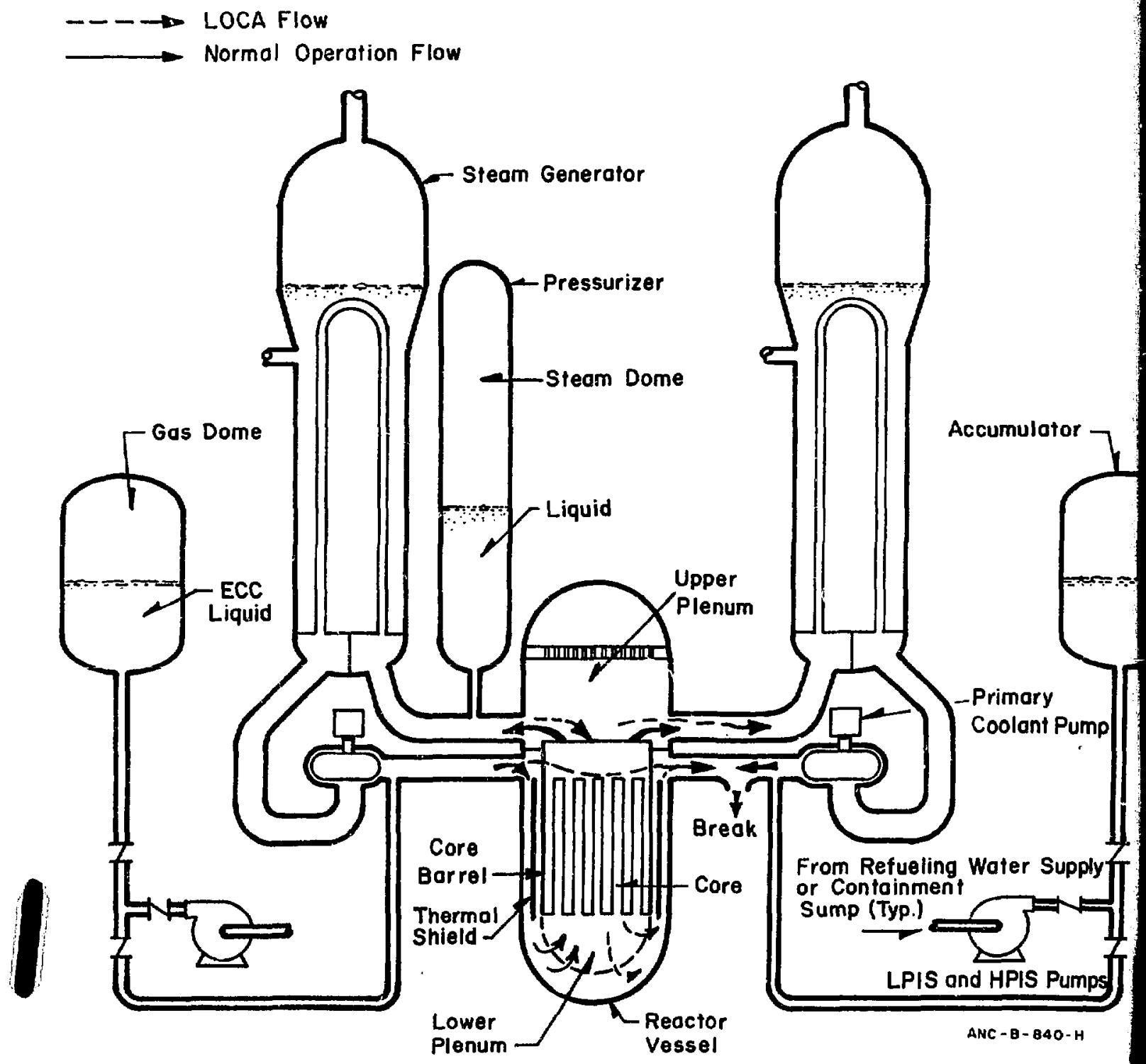

Figure A-1. Typical U.S. Multiple Loop PWR System. 


\section{G SYSTEM DESIGN CONCEPTS FOR CONTEMPORARY PWR's AND BWR's}

ergency coolant supply systems is described for those plants of current and near future characterizes the generic fealures which typify the plants of several manufacturers.

loops of a multiple loup U.S. PWR is shown in rough scale in Figure A.l. As shown, this ponents and all inlet and outlet pipes to the reactor vessel above the top of the core. This losure around the reaclor cure that has no penetrations and thus has a high potential for for all possible pipe breaks in the primary coolant circuit. The PWR ECC supply systems upper regions of the inlet annulus, depending on the manufacturer, are intended for ottom.

Flow

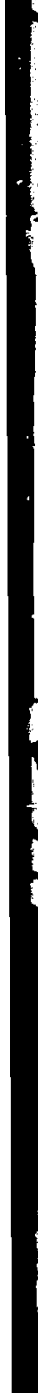

Steam Generator

-Pressurizer

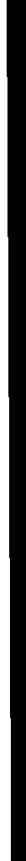

-Steam Dome

(1)

r

Liquid

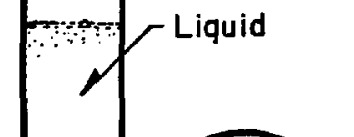

Upper

Plenum
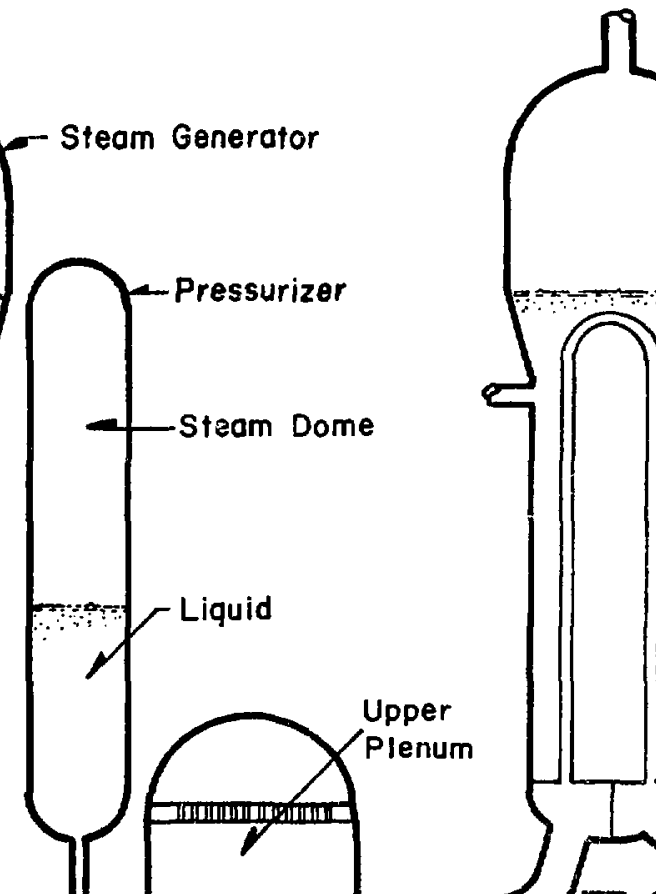
Passively artivaled (gas dome) accumulators (Atorape: lanks) and low capacity pumping systems do reactor primary system. Activation of the various FCC. subsystems depends on the sizs: of the primary pressure injection system (HPIS) pumps, although utilized for all hreak sizes, are intended primarily for small injretion system (LPIS) pumps are used when breaks are sufficiently large that the primary system) approximately 170 psia and are intended for long term core reflooding. The aerumulator sy stems, although are intended primarily for large break sizes for which the primary system depressurization falls below the pre? in the arcumulators. The accumulator pressure varies among reactor manufacturers and ranges from 750 psia psii.

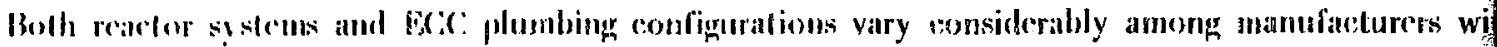

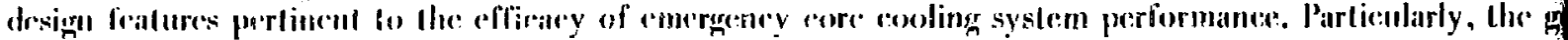

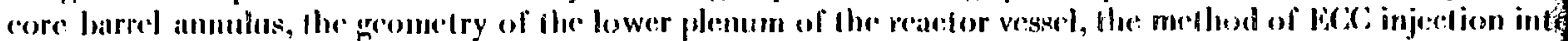
and the quantity of available aceumulalor waler ante imporlant fatures that vary. The varying configurat

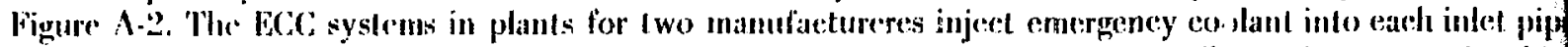
however, varies between 60 and 90 degrees for the two different plant designs. The ECC: system of a thir injects the comergency coolant directly into the upper region of the inlet annulus.

Figure A-3 is a lypical bar chart illustrating, for a range of break sizes, the various system componer reflooding of the corc for all prifuary system pipe break sizes. The typical unimpeded delivery capability for illustrated in Table A-I.

PWR configurations of other than U.S. designs are very similar in the design of the primary coolant circ The German version (Siemens) injects aceumulator coolant into both the outlet and inlet pipes.

\section{TABLE A-I}

TYPICAL DELIVERX CAPABILITY FOR THE VARIOUS PWR-DCC SYSTEMS

\begin{tabular}{|c|c|c|c|}
\hline $\begin{array}{c}\mathrm{TiCC}_{\mathrm{C}} \\
\text { Sys vem } \\
\end{array}$ & $\begin{array}{c}\text { Initiating } \\
\text { Pressure } \\
\text { (psid) } \\
\end{array}$ & $\begin{array}{l}\text { Total } \\
\text { Number of } \\
\text { Component.s }\end{array}$ & $\begin{array}{r}\text { Number } \\
\text { Assumed } \\
\text { Available } \\
\end{array}$ \\
\hline $\begin{array}{l}\text { Charging } \\
\text { pumps }\end{array}$ & $\begin{array}{l}1000 \text { to } \\
2750\end{array}$ & 2 & 1 \\
\hline HPIS pumps & 1500 & 2 & 1 \\
\hline Accumulators & 200 to 750 & $\begin{array}{l}2 \\
\text { or } 2 \\
\text { or } 3 \\
\text { or } 4\end{array}$ & $\begin{array}{l}2 \\
1 \\
2 \\
3\end{array}$ \\
\hline I.PIS pumps & 120 t.o 600 & 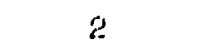 & 1 \\
\hline
\end{tabular}





\section{Thermal Shield}

Core Support Borrel

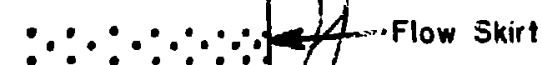

$\therefore \because \because \because \because \because \because$

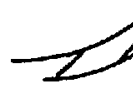

Combustion Engineering,Inc.

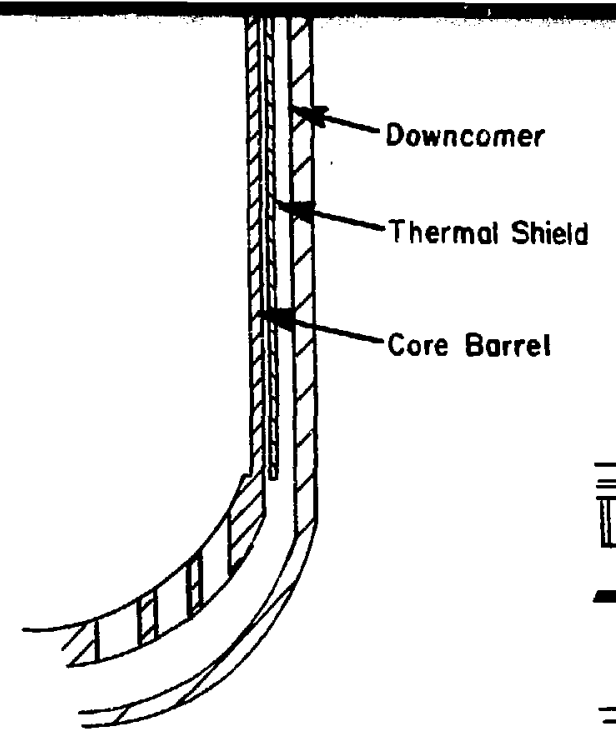

Westinghouse Electric Corporotion
Bobcock \& Wilcox

Company
Babcock \& Wilcox Company

$A N C-8-858-H$

Figure A-2. PWR Configurations for Various Manufacturers' Designs. 


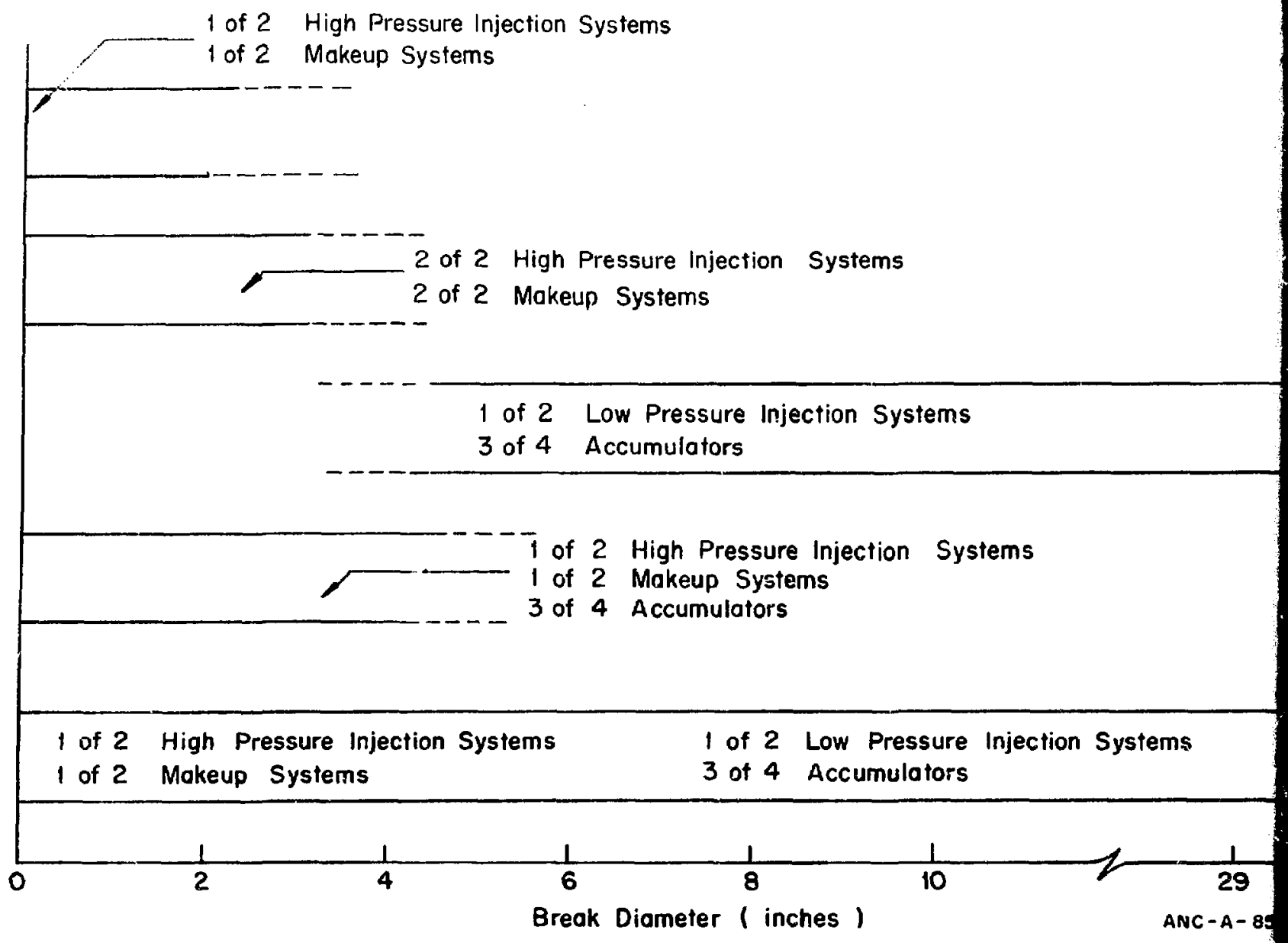

Figure A-3. Typical Range of Assumed Core Protection Provided by Action of Combination Systems.

\section{BWR ECC DESICNS}

$\Lambda$ schematio represenlation of a contemporary U.S. BWR system is shown in rough scalo; in Figure A.4 reactor eorr is enclosed within an inner vessel in an arrangement similar to that of the PWR in that the system can (without coolant penetration) to a level about two-thirds the core height. The actual level is dictated by the clevati the jet inumps.

Th. 1969) product line HWR cutergeney ceroling metwork consists of one high pressure core spray (HPCS

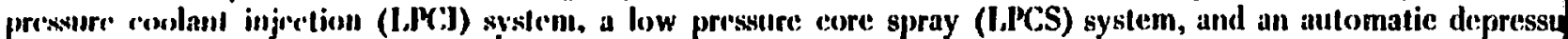
(AIS). 'Ilu two corr spray systems are designed (1) presvide both top spray cooling and bottom flooding, the acrumulal iun in the lower plenum of the coonlant not evaporated during spraying. The L.PCI system refloods the from llo" rore: top. All rmergency coolant injection subsystems utilize pumps for coolant injection in contrast to

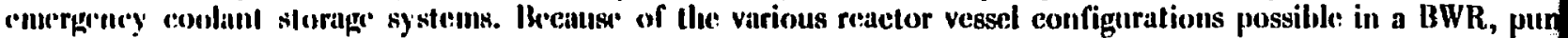

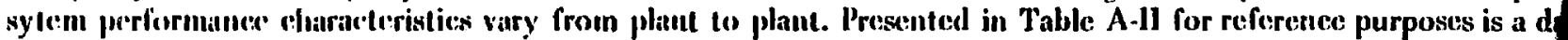
lhe comirerency cooling systems in a slliblard 2400 MW(t) BWR plant.

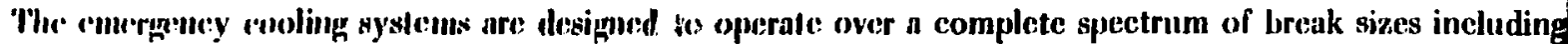
necidenI. $A$ prerformance copahility chart is shown in Figure A-5 for both a recirculation line break and a ste:am lin 


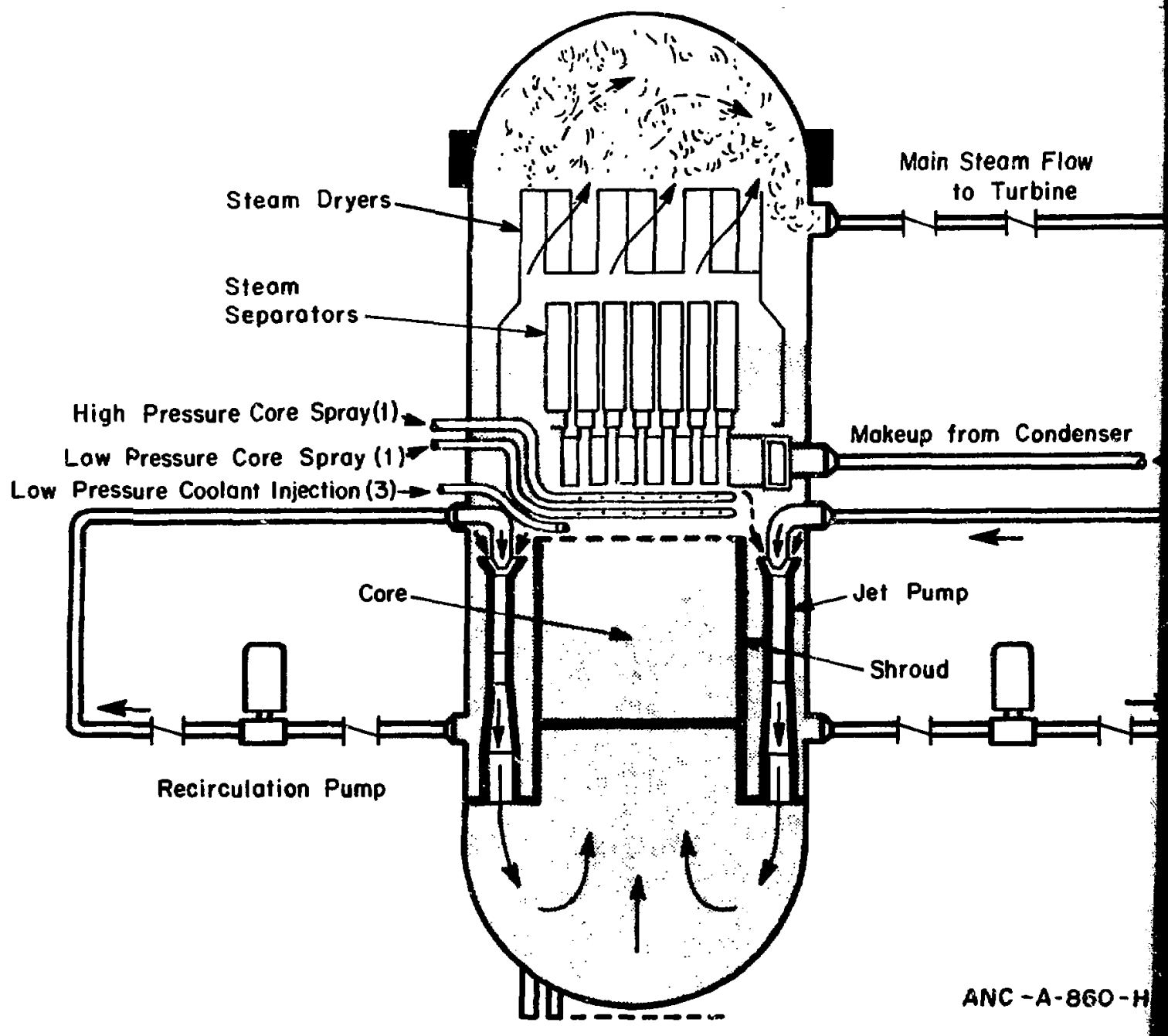

Figure A-4. Typical U.S. BWR System.

The current German (AFG) version of the BWR incorporates an integral mechanical pump in place of th eliminating the recirculating lines and thus also eliminating a reeirculating line brcak. Multiple coolant makeu powered from off-line sources act as the ECC supply in a fleoding mode similar to that of the PWR. A pip makeup water line or rupture of a stcam linc ereates a DBA condition which for this BWR concept resu depressurization time of several fundred seconds as compared to a calculated 30 -second depressurization time fo

Thr currint Swedish (ASES-ATOM) version of the BWR also incorporates internal medhanical pumps.

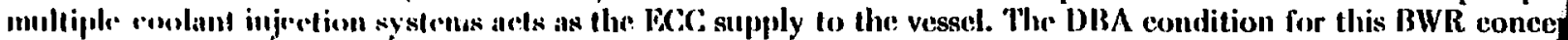

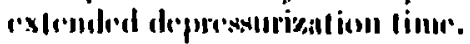




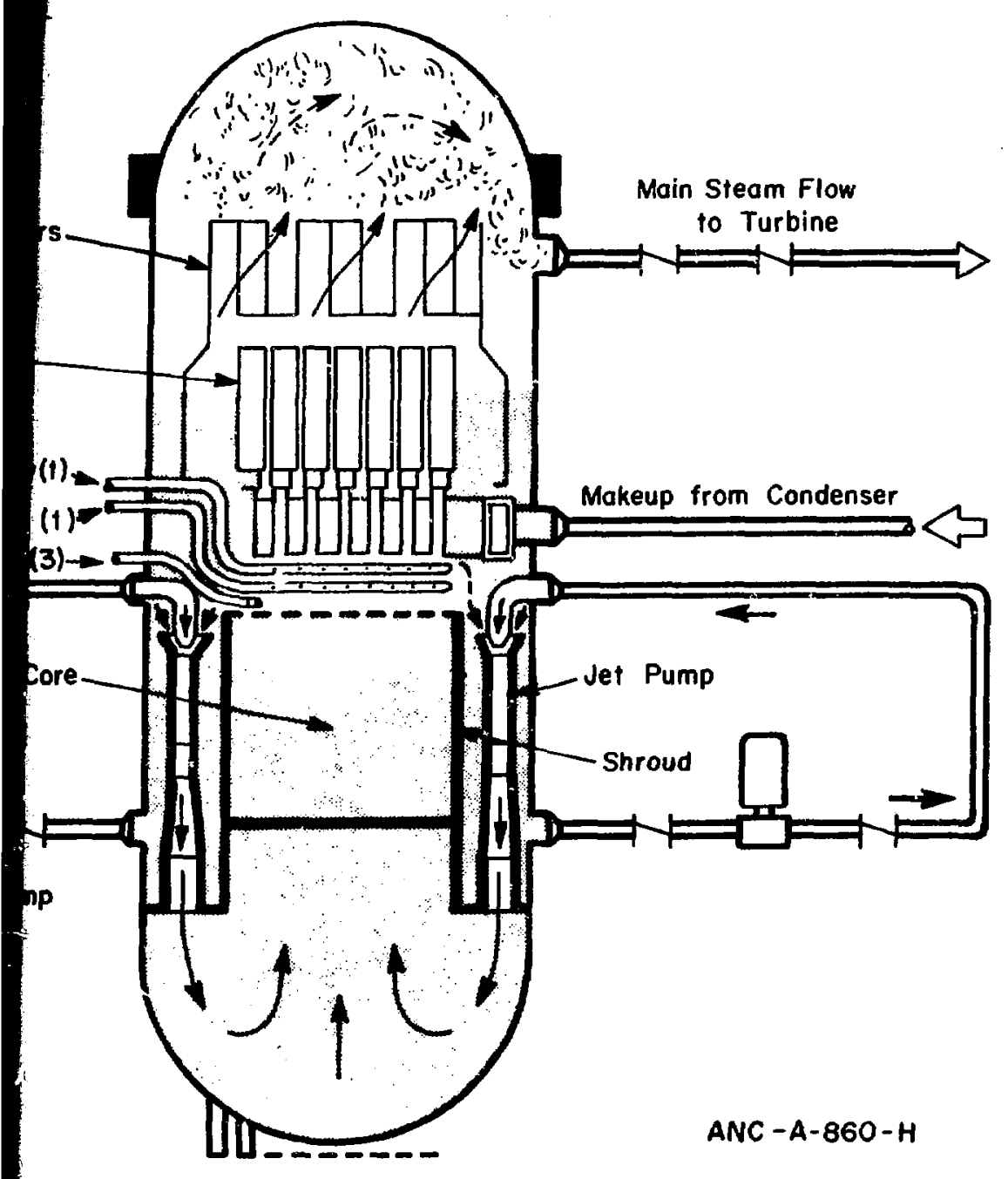

Figure A-4. Typical U.S. BWR System.

$n$ of the BWR incorporates an integral mechanical pump in place of the jet pump thereby us also eliminating a recirculating line brcak. Multiple coolant makcup systems normally e ECC supply in a flooding mode similar to that of the PWR. A pipe break of a single: eam line crcates a DBA condition which for this JWR concept results in a calculated seconds as compared to a calculated $\mathbf{3 0}$-second depressurization time for a U.S. IBWR.

M) version of the BWR also incorporates inlernal mechanical pumps. A combination of the WC.C supply (o the vessel. THe D)BA condition for this BWR conecpl also results in ant 
Design flow for L'acl] System

Nurnber

Huintion

Installed

Gapaseity (\%)

100

1130

200

Automatic

depressurizing

valves

6

20

100

$33-1 / 3$
$1300 \mathrm{gpm}$
$4625 \mathrm{gpm}$

\begin{tabular}{l}
\hline Flow \\
\hline $1300 \mathrm{gpm}$ \\
$4625 \mathrm{gpm}$
\end{tabular}

$800,000 \mathrm{lb} / \mathrm{hr}$

$4625 \mathrm{gpm}$

$4970 \mathrm{gpm}$
1125

119

20

[a] Tifferential pressure between the reactor vesisel and the primary containment, in sugure inch.

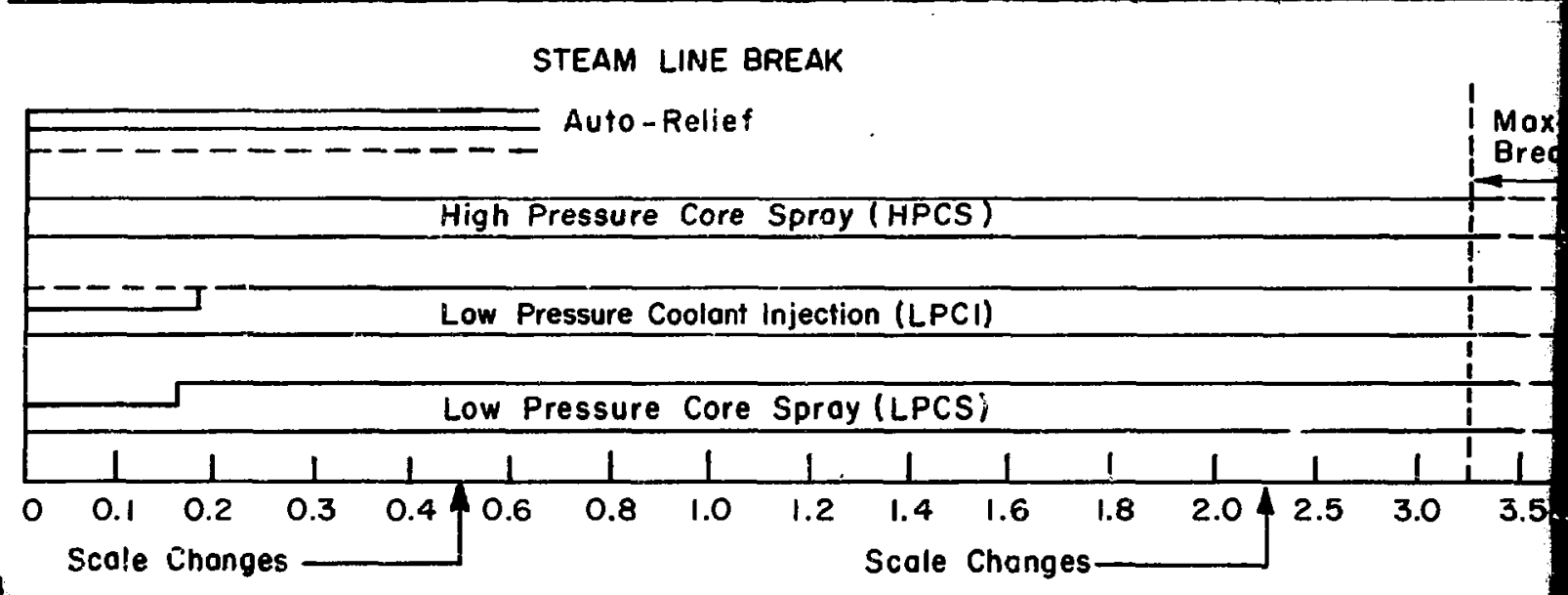

LIQUID LINE RELIEF

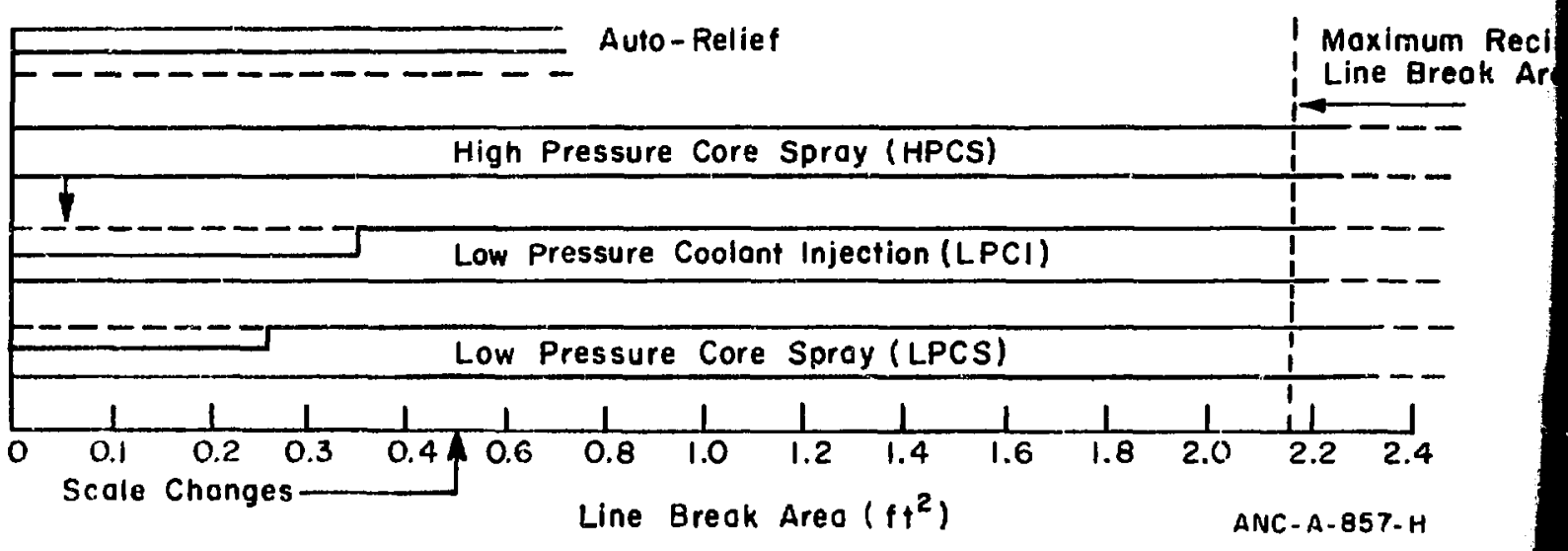

Figure A-5. Typical Range of Assumed Core Protection Provided by Action of Combinati? Sys teills. 
Design Flow for Lach Syitem

Capacity (\%)

100
$1300 \mathrm{gpm}$

$4625 \mathrm{gpm}$

20

100

$33-1 / 3$
$800,000 \mathrm{lb} / \mathrm{hr}$

$4625 \mathrm{gpm}$

4970 gpin
1125

119

20
Jressur: Ranese (pisid)

1130 t.o 0
1130 to 0

265 to 0

225 to 0

een the reactor vessel and the primary containment, in pounds per

\section{EAM LINE BREAK}

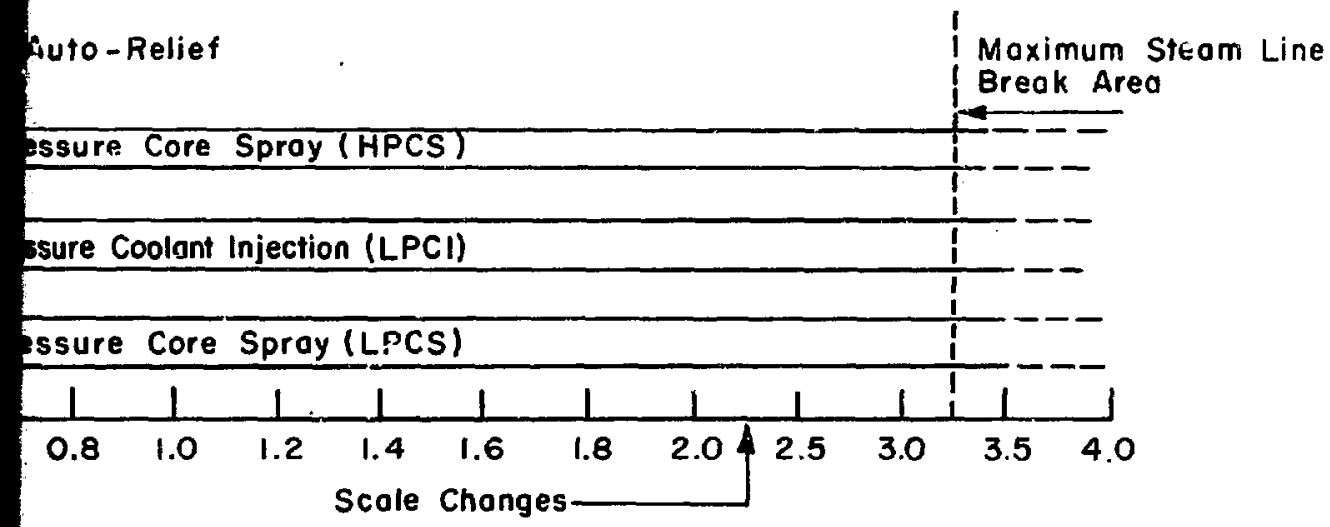

QUIO LINE RELIEF

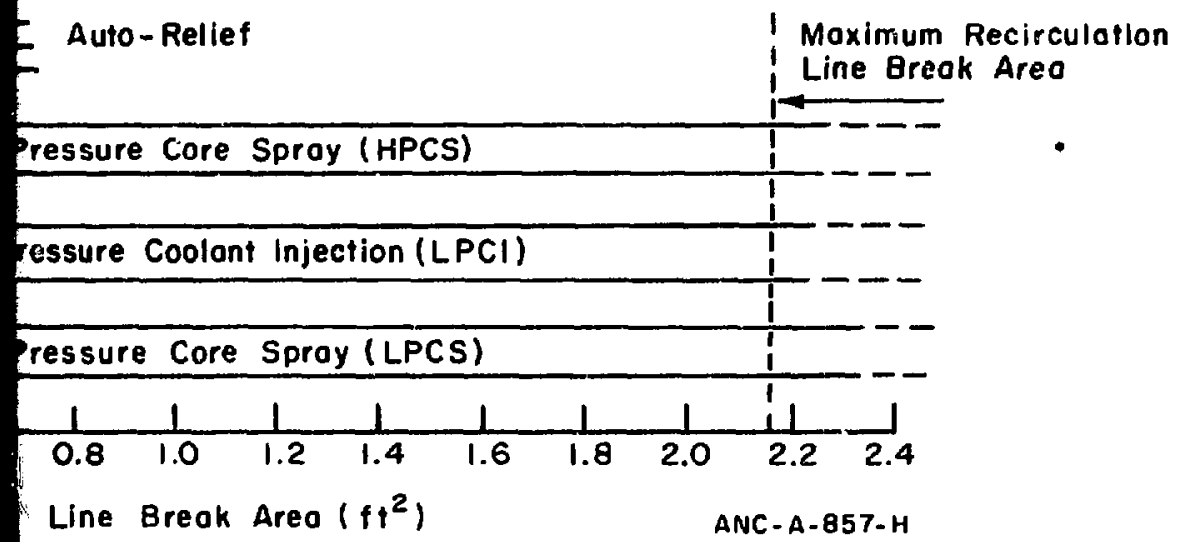


The events and processes of an I,OCA are devcloped to illustrate the system behavior and pheno accounted for by the calculationai methods in order to preseribe the design and performaner requirements fior

\section{PWR-L,OCA BEHAVIOR}

Figure B-I depiets the generalized LOCA behavior for a postulated large break in one loop of a mul coolant circuit. This characterization of the accident is derived from many calculations carried out for locations for current PWR designs. The numbers on the figure are indexed to the following description loss-of-roolant process.

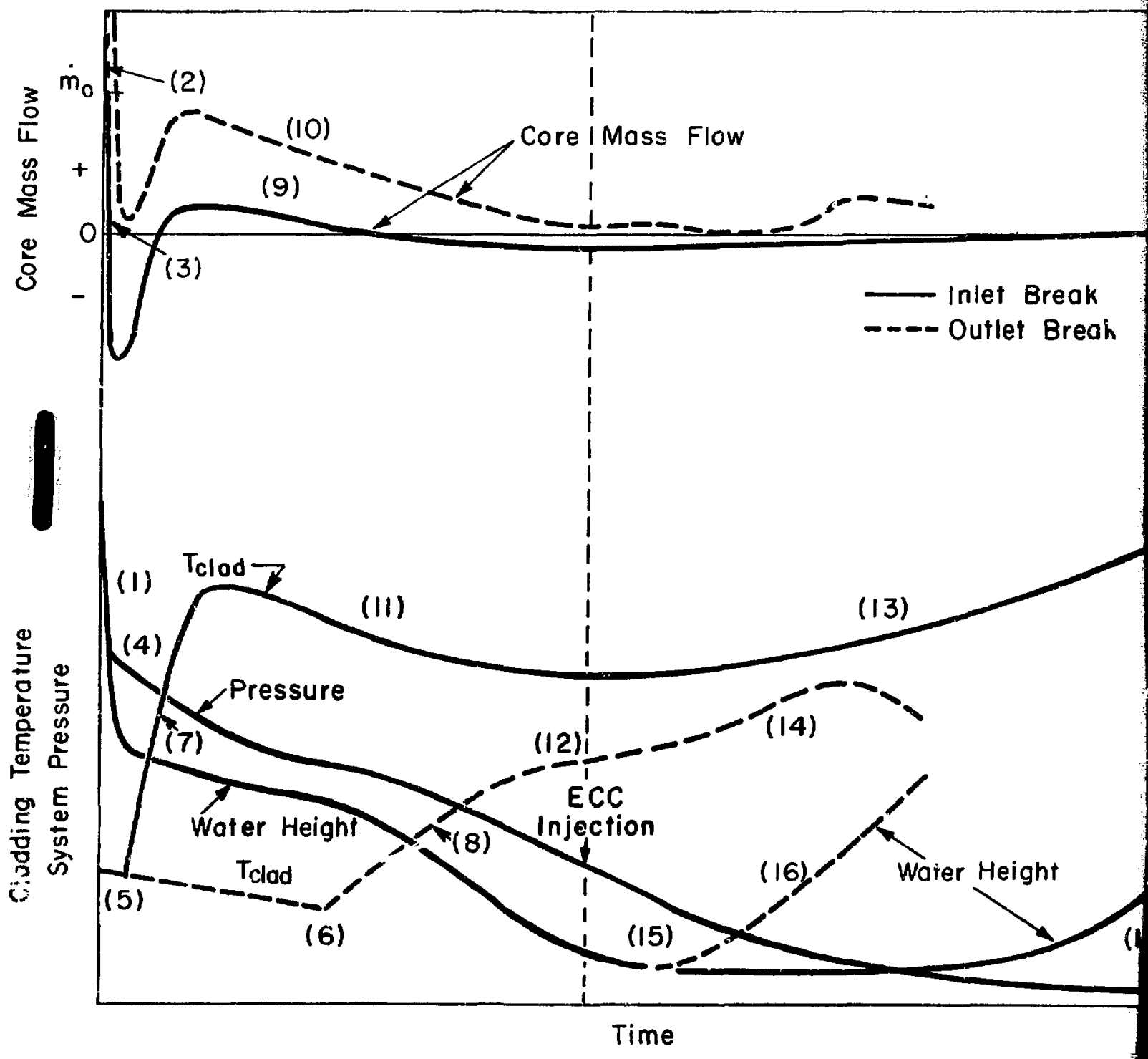

Figure B-1. Generalized Loss-of-Coolant Behavior for Large Pipe Breaks in 


\section{ION OF LOSS-OH-COOLANT ACCIWH'T FOH PWR'S AND HWR's}

A are developed to illustrate the system behavior and phenomena which must be a order to preseribe the design and performanee requirements for ECC systems.

CA behavior for a postulated large break in one loop of a multiloop PVR primary e accident is derived from many calculations carried out for different pipe break mbers on the figure are indexed to the following description of the course of the

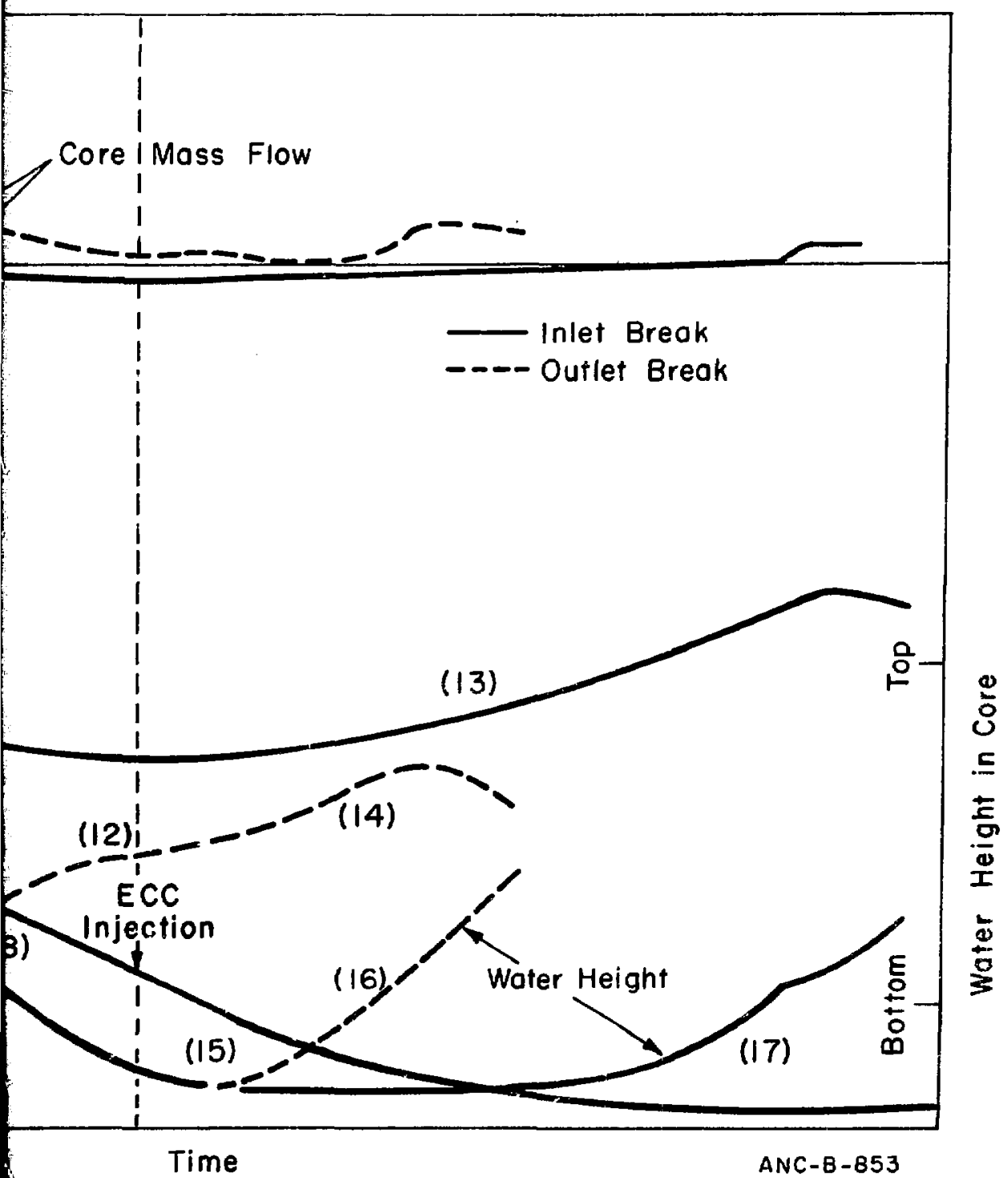


Immerliatcly following the pripe lareak, as Iloe primary coolant is expelled from the ruplute, the syster

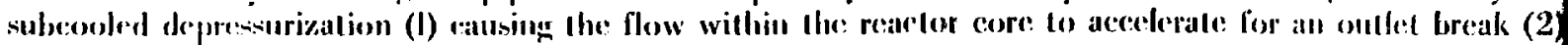
inlet break (3). A. the systeon drpiressurizalion continues (4) the local fluid saturation pressure is ceached an an allendant fluil density decrease, oceneurs in the core as stram bublle growth is initialed. Wilhin the corc fluid density (moderator loss) causes the core power gencration to decline within a few hundred milliseconds decay heat power level (approximately $6 \%$ of the operating power).

For the inlet break conditions the reduced core llow commensurate with coolant voiding in the core cal decreasc in heat transfer from the fucl to the coolant and initiate the critical heat flux (CIIF), or departure (DNB) (5). For the oullet break condition the core flow increase (2) tends to of fset the density decrease an presterved for an costented period until the local fluid conditions within the core are degraded sufficiently th: is reached. For cither break, the ahrupl decrease in heal transfer (5) (6) allows the large amount of stored ene redistribulc witl a resultant rapid increase in fuel cladding temperatures (7) (8).

For the inlet break condition, at several seconds into the depressurization process the core mass flow $r$ reduced because of nearly balanced fluid resistance paths to the break. For the outlet break condition, the break from the eore: region is markedly lower and resulis in a continued significant upward core flow (10). Th core flow hislories (9) (10) resperelively influence the elalding temperature histories for the inlet and outlet br

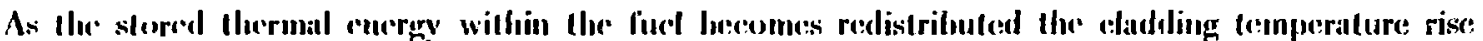

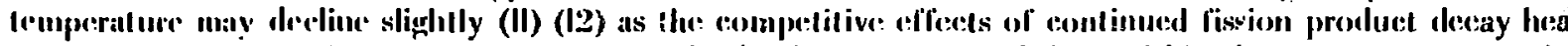

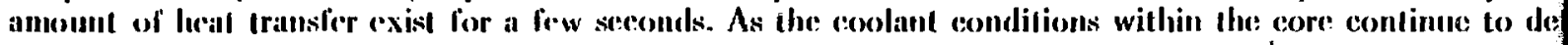
temperature risis (13) (14) (:ommensurate with adiabatic conditions dietated hy the local fission product decal

When the cladding temperature exceeds 1200'F lor cither break condition, structural distortion, zuc cladding, Inay develop. Ballooning is postulated to result from a combination of the decreased strength of temperaturc increases) and the increasing differential pressure between the internal fuel rod pressure and $t$, syslem pressire.

As the coolant is expelled into the containment structure surrounding the reactor, the primary depressurize with an accompanying decrease of liquid level within the reactor vessel (15). When the syst below the gis dome pressurc within the ECC accumulators (or core flooding tanks), relatively cold auxilia into the appropriate inlet pipjing (or upper core barrel region) in an attempt to replenish the liquid inventory of the reactor vessel.

For an outlet hreak condition, soon after aceunulator injection begins, the liquid inventory in $t$ replenished to the hollom of the core (16). Core flocoling is maintained by the low pressure coolant inject accunulator inventory is spent.

For an inlet break, some batekflow from tlee core and eontinued boiloff of the lipuid in the lower ple: up the downesmer which tends to inhibit the: entry of auxiliary eoolant to the lower plenum. In addition inlet pipes of the unbroken loops Iends to entrain some of the injected coolant and this entrained coolant the downcomer anmulus to the break. Thes: conditions lcad to the postulated "accumulator ECC decompression eontinues and the system steam flow rates decrease, the influence of gravity overcomes the $e$ the lower plenum begins to fill (17).

As the lower plenum fills and coolant reaches the bottom of the core, steam begins to be generated. some licuid, rises in the core and cools the cladding. For the inlet break, the steam must escape from througl Ihe steam generilors and pumps in order to reach the system vent, or pipe break (Figure A.I of $A p$ in passing throught Ilac various system components and particularly the steam generator where additional end serondary systcm, is impsedod by frictions. T'le frietional pressure drop can reach a value of several pounds pes bnchpressure on llic refloodiun proress which eompetes against the head of water in the downcomer attem inlo Ilu" core. 'I'he downcomer head in most current reactor designs can develop to a maximum head of $\sim 7$; process is relatively steady-state. If oseillatory effects occur as a result of the coupling between the iner? gravity on the liquid in the downeomer and the coupling between the inertance of the liquid in the complianc'c of the compressible stean volume above the flooding front, the average driving head could be les drivilig head, thus lowering still furlher the time-averaged flooding rate within the core. The oscillatory however, provicle improved heat transfer in the carly part of the flooding process. 
flant is expelled from the ruphure, the system rexperiences a rapid far core to accederate for an ondlel break (2) or decederale for an wa: Jowal fluid saturation pressure is reached and fluid flashing, wilh buthble growth is initiated. Within the eore region the decreasing of decline within a few hundred milliseconds to the fission product (r)

mensurate with coolant voiding in the core can cause a large abrupt ate the critical heat flux (C.HF), or departure from nucleate boiling ise (2) tends to offset the donsity decrease and high heat transfer is s within the core are degraded sufficiently that CIIF (6) ultimately (5) (6) allows the large amounl of stored encrgy within the fuel to cratures (7) (8).

atepressurization process the ure mass flow rate (9) is significantly te break. For the outlet break condition, the fluid resistanes to the ontirated significant upward toore low (10). These differences in thr: mperature histories for the inlet and outlet break conditions.

realistribuled the aladeling lemperature rise may torminate or the: fexter of contimed fission produce decaly heating and some limiled at eonditions withiu the core continus: to deteriorate the chaddling ons dietated loy the local fission produet denay heat rale.

her break condition, struetural distortion, such as hallooning of the: a sombination of the deerrased strength of the eladding (as the: between the internal fuel rod pressure and the decreasing extornal

fure surrounding the reactor, the primary system continues to ithin the reactor vessel (15). When the system pressure decreases core flooding tanks), relatively cold auxiliary coolant is injorted an attempt to replenish the liquid inventory in the bottom plenum

injertion legrins, the liquid inventory in the bollom plenum is aintained by the low pressure coolant injection systems when the

hinued bojloff of the liepuicl in the lower jolenum cause: ste:am flow y erolant to the lower plenum. In addition, the steam flow in the: injected coolant and this entrained coolant is then carried around fad to the postulated "aceumulalor ECC bypass" situalion. As zase, the influence of gravity overcomes the entrainment forces and

of the core, steam begins to be generated. The steam, cntraining inlet break, the steam must escape from the system by passing system vent, or pipe break (Figure A-I of Appendix A). The ste:am, arly the steam generator where additional energy is added from the drop can reach a value of several pounds per sefuare inch causing a the head of water in the downcomer attempting to drive coolint signis can develop to a maximum head of $\sim 7.1 / 2$ psi if the flooding 3 a result of the coupling between the inertance and the force of etween the inertance of the liquid in the downcomer and the front, the average driving head could be less than the stealy-state ding rate within the core. The oscillatory flooding front could, lawoding process.

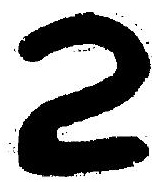




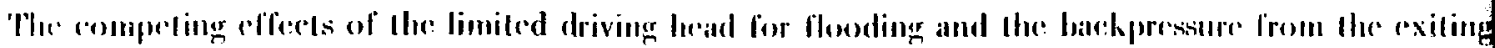

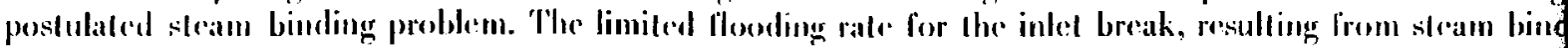
heat translier in the core relalive to that which would exist for higher flooding rales for an oullel break. W effeets are involved for the inlet break, additional subtheties. such as the effects of conlainment batekpressue on heat transfer and such as the compressible-flow acceleration-pressure drops due to energy being Iransferre side of the steam generator to escaping steam from the primary system, become imporlant.

The lemperature that the fuel eladding can atlain without loss of structural in Legrity is determined, for by the anount of oxygen taken up by the cladding during metal-water reactions which become significant $1800^{\circ} \mathrm{F}$. $111800^{\circ} \mathrm{F}$ the reaction rale is low lott as the temperature increases to $2000^{\circ} \mathrm{F}$ and above, the rapidly. At $2300^{\circ} \mathrm{F}$, for example, the oxygen uptake is such that reaction clurations exceeding several to sufficient combrittlement that upon quenching of the fuel eladding by ECC, the structural integrity of the clae assure a definable heat transfer geometry within the hotter regions of the core.

The forcoroing, intended to depict the general system behavior during an LOCA for a PWR, has conditions which are experted to establish the ultimate requirements for ECC system design. The magni "ffect of brak size and localion on the DBA is shown in Figgre B-2. The ealeulations for developing the f the reactor mamufieturers and those performed independently by $\Lambda$ crojet Nuclear Company in conjunetio

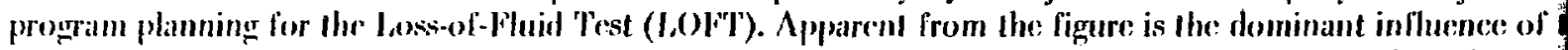
deternining the requirements of ECC designs for PWR's. llowever, the very largest break slould not be con demanding on ECC design for all PWIR's.

\section{BWR LOCA BEHAVIOR}

Figure B-3 depiets the generalized loss-of-coolant accident behavior for a postulated break in either t lines or the steam outlet lines of a rontemporary boiling water reactor system. The numbers on the figun? following alescription of the course of the loss-of'-conlant process.

Inmedialely following a steam line or recirculation line break of a BWR the system experiences a $v$ depressurization because a significant amount of the fluid in the system during operation is at saturation remainder being slightly subcooled. The loss of onc recirculating loop eauses the core mass flow to drop rap? the initial value (l) as the other systems continue to provide coolant supply to the lower plenum, since a larg contains steam, at the outset, the depressurization process is relatively slow (2), and at several seconds into th isolation valves in the outlet line close requiring that all system coolant exit from the pipe break region. Si version of the BWR. incorporates the internal jet pump design, all pipe breaks, including recirculation and gencral. produce the ceffecl of an outlet break in a l'WR; that is, the depressurizing coulant flows in the not through the core as illustraled in the tigure.

At the approximate time the liquid level within the reactor drops to an elevation at which the jet pum the mechanical pumps in the recirculation line are coasting down and shortly cavitate dropping the core ma These conditions promote coolant starvation within the reactor core and initiate CHF in the hotter regions liquid level in the: outer annulus around the core barrel drops to the elevation of the recirculation line ou. break beconics steam and the depressurization rate is increased (4). Simultaneously, the saturation pressur? plenum of the reactor vessel is reached and a process called lower plenum flashing is initiated (5). During tends to flasl, violently and surges into the core region. The potential for significant cooling exists st temperature rise may be terminated (6) and the cladding temperature may be restored to the fluid saturatio coolant inventory in the lowcr plenum is spent from flashing, the system pressure continues to decli temperaturc again rises in the hotter zones of the core and experiences DNB a second time (7). The cladd rapidly until the energy redistribution within the fuel pin is complete at which time decay lieat limits the rs. rise (8). Shown in the figure for completeness is the continued temperature rise from the carly event of CllF. temporal ure limit $\left(9^{\prime}\right)$ assuming no cooling due to lower plenum flashing. As the system pressure continass to spray system above the reactor is initiated and top sprily flow is developed at about 260 psiti. 'l'he spray? eanister walls providing a raciiation sink for heat removal from the fuel pins. The resulting steam from provides some convective heat removal from the cladding surface. This cooling process tends to slow the lowir reirtor vessel plenum is filled ly the aceumulated spray and LPCI system coolant inventories and a c similar lo Ihat for the PWR is initiated. 


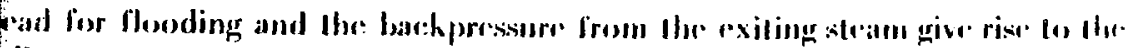

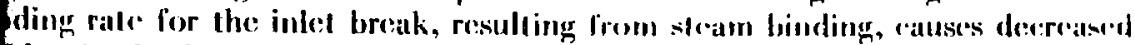
In exist for higher flooding rates for an outlel break. Where lhese compering abtleties, such as the effects of containment lackpressure on entrainment and ceceleration-pressure drops due to energy being transferred from the secondary he primary system, become important.

tain without loss of structural integrity is determined, for zirconium-ellad fucls. during metal-water reactions which become significant at temperatures alowe s the temperature increases to $2000^{\circ} \mathrm{p}$ and above, the reaction rate increasiss ake is such that reaction durations exceeding several tens of seconds cause: fuel cladding by ECC, the structural integrity of the cladding is insufficient Io hotter regions of the core.

ral system behavior during an LOCA for a PWR, has emplasizeal the: IBA timate requirements for ECC system design. The magnitude of the calculated own in Figure B-2. The calculations for developing the figure include those ly cependerotly by Aerojet Nuclear Company in conjumelion wilt the design and . Apparent from the figure is the deminant influenece of the large iule loreak in WR's. However, the very largest break should not be concluded to be: Hhe mest

lant accident behavior for a postulated break in cither the liguid recirculation boiling water reactor system. The: numbers on the ligures are indexed to the plant process.

ulation line break of a BWW the system experiences a very limiled subroulcol the fluid in the system during operation is at saturation conditions, with the e recirculating loop causes the core mass flow to drop rapidly to about one-half o provide coolant supply to the lower plenum, since a large volume of the vessill process is relatively slow (2), and at several seconds into the transient, the stcam at all system coolant cxit from the pipe break region. Since the contemporary pump design, all pipe breaks, including recirculation and stoam line breaks, in PWR; that is, the depressurizing coolant flows in the: normal upward diretion

hin the rearlor drops to an elevation at which the jet punips become uncovercel, coasting down and shortly cavitate dropping the core mass flow to nearly zero. in ihe reaclor corc and initiate CHF in the hotter regions of the eore (3). As Ille barrel drops to the elevation of the recireulation line outlet, the flow out the' e is increased (4). Simultaneously, the saturation pressure of fluid in the lower cess ealled lower plenum flashing is initiated (5). During this process the fluid e region. The potential for significant cooling exists sucli that the cladding ladding temperature may be restored to the fluid saturation temperature. As llie: from flashing, the system pressure continues to decline and the cladiling eore and experiences DNB a second time (7). The cladding temperalure rises fuel pin is complete at which time decay heat limits the rate of the temperalure e continued temperature rise from the early event of C.IIF (3) on through to the: lower plenum flashing. As the system pressure continues to drop, a high jressirurc op sprity flow is developed at about 260 psia. 'The spray lends to wet the fiucl removal from the fucl pins. The: resulting steam from canister wetting also cladding surface. This cooling process tends to slow the heatup rate until the ulated spray and LPCI system coolant inventories and a core reflooding process

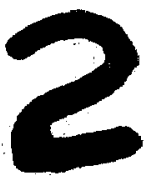




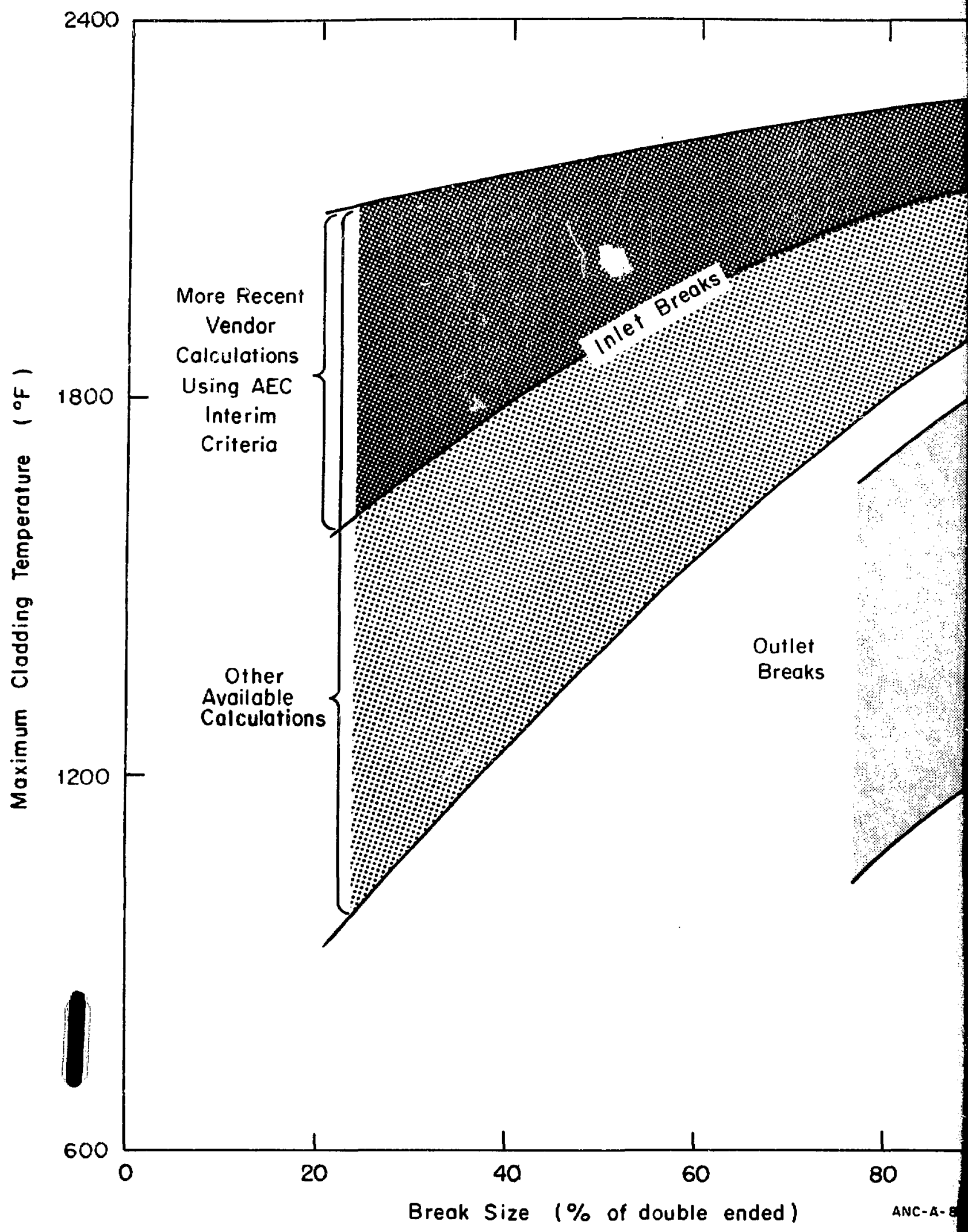

Figure [-2. Generalized Comparison of Maximum Cladding Temperature for Various Primary Break Conditions in a PWR. 


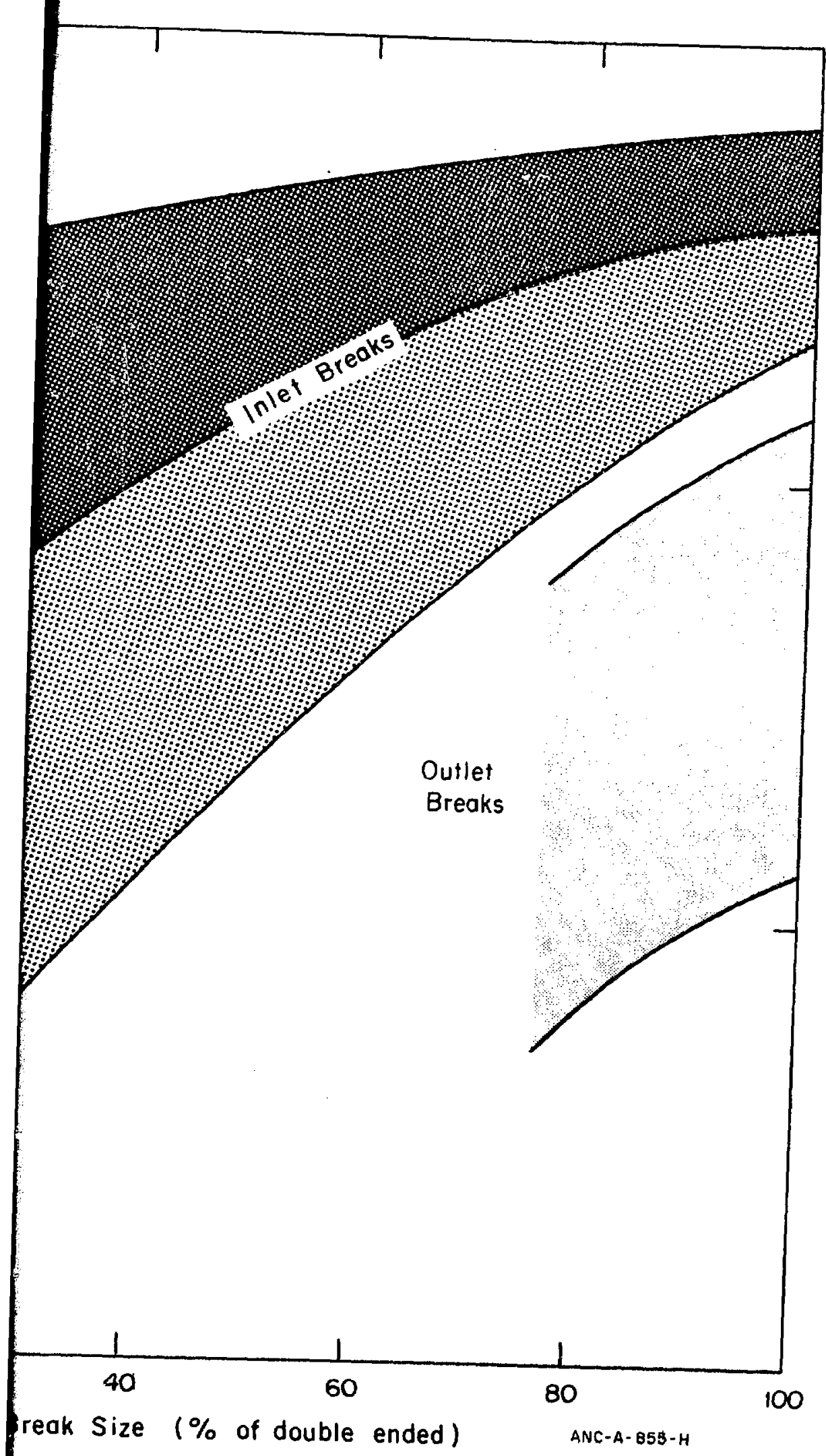




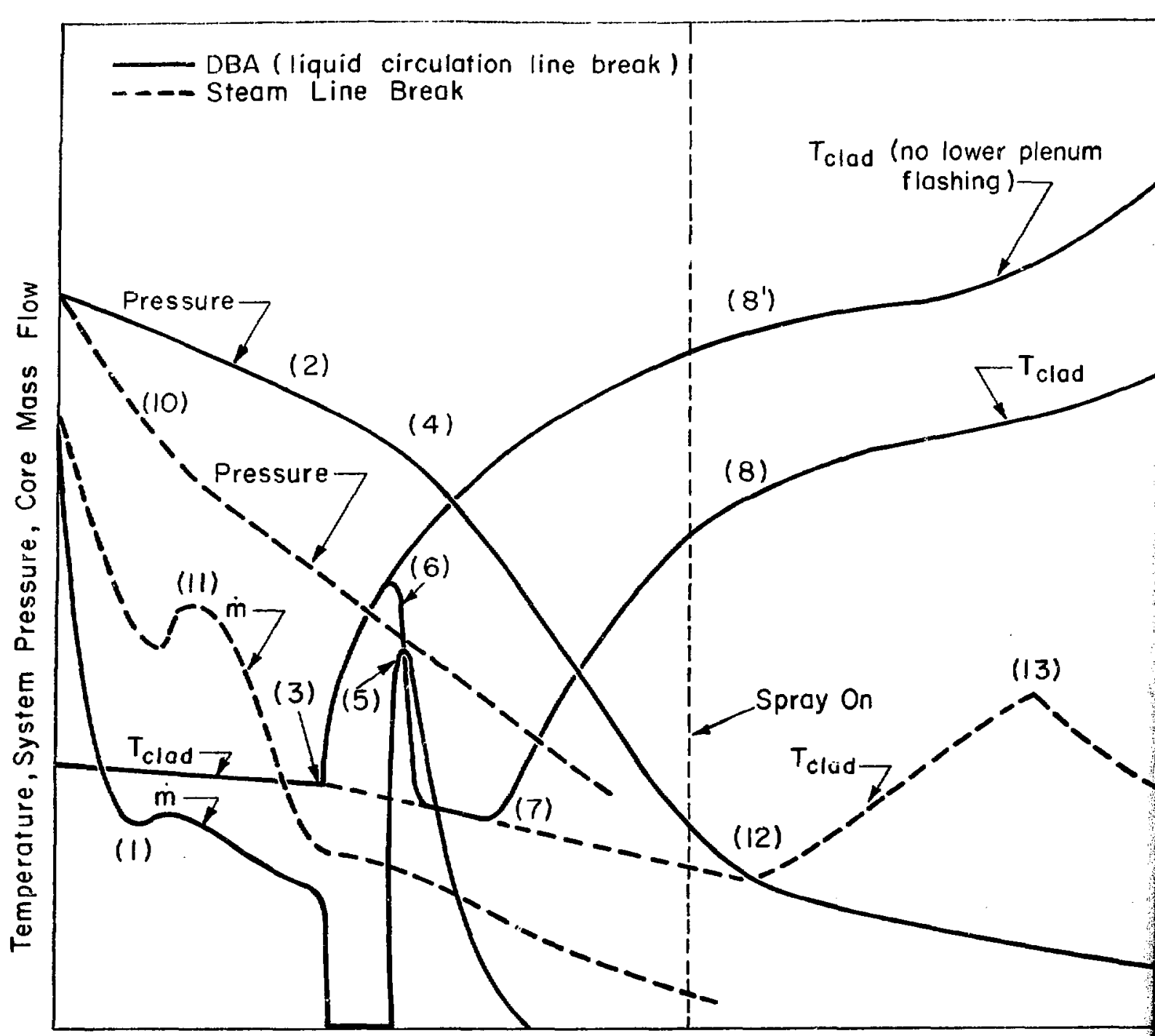

Time

Figure B-3. Generalized Loss-of-Coolant Behavior for Large Pipe Breaks in

For the lower cladding temperature history (8), the cladding temperature turnaround (9) results fr flooding at the bottom of the core. For the upper cladding temperature history $\left(8^{\prime}\right)$, the effects of metal-wat seen to cause a significantly increased rate of temperature rise prior to the event of flooding (9').

For the stram line loreak, the various events arre depicted by dashed lines in Figure B-3. The pressu considrrally more rapidly (I0) Iltan for the receireulation line break. Since steam venting is taking place at reartor veswel the lipuid fratetion in the system remains high and all recireulation line systems comtinue to op fow is thes secto lo comlinue (II): however, the flow eventually decreases as the pressure decay causes the ree pumps to cavitalte. 'The llashing process continues to provide reasonable core flow and at lcast sufficient stea. 'The attendant cladding temperature indicates that nearly all the stored energy within the fucl is removed uf the coolant conditions can no longer support the heat transfer required to keep the cladding temperat saluration temperature (12). At this point the cladding temperaturc begins to rise as a result of the small stored energy and decay heat energy. Up to this time most of the fluid lost from the system as a result of bern stram and some two-phase mixture; that fraction of liquid having insufficient enthalpy to flash remain The additionil inventory necessary to fill the Iower plenum to the bottom of the core and effect early tu tomperature rise (1 3) is, therefore, considerably less than for the recirculation line break. The general behavi effect of metnl-waler reaction, and embrittlement are sufficiently similar to those of a PWR that ad unw wirriunled. 


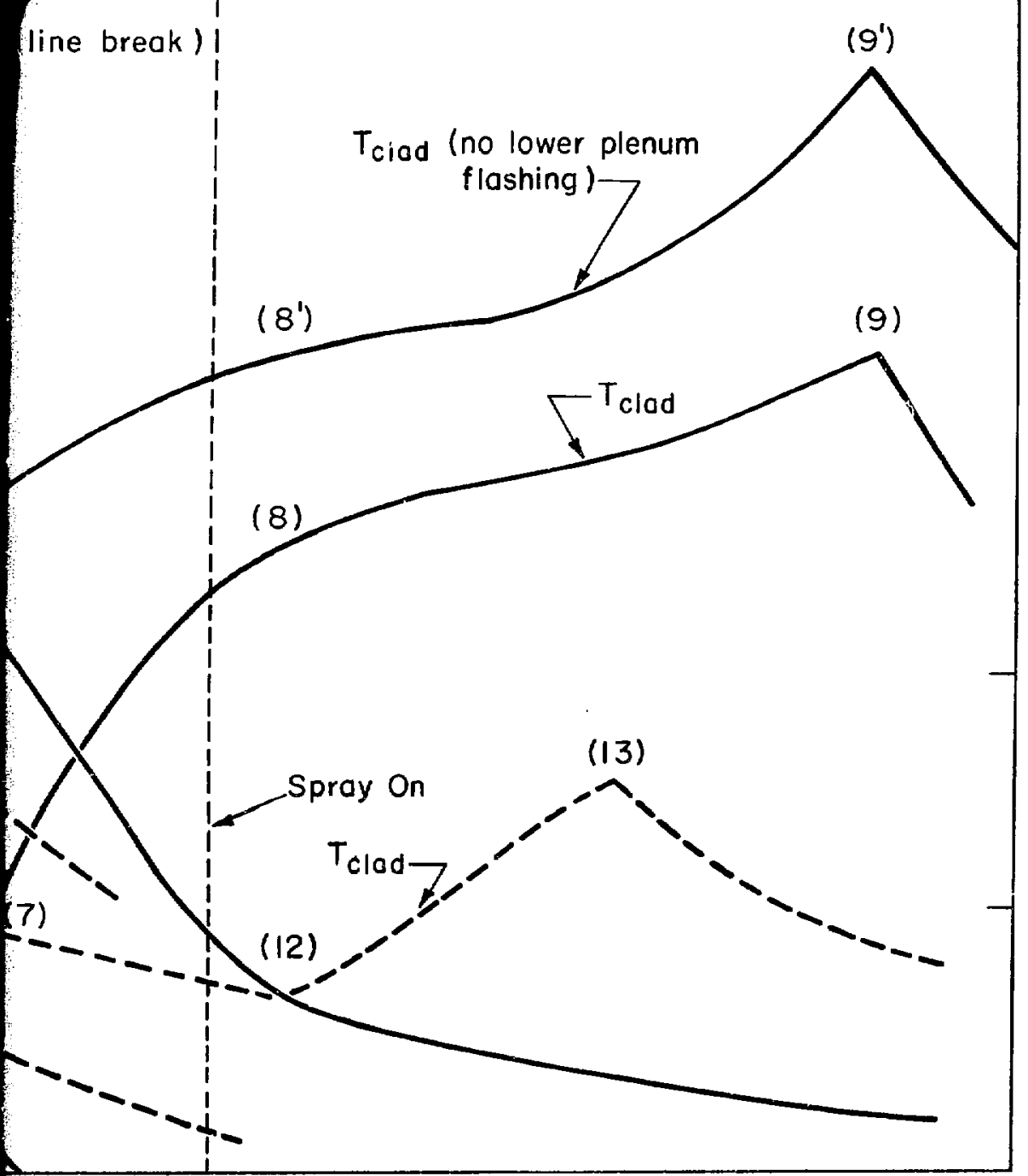

Time

$A N C-B-854-H$

s-of-Coolant Behavior for Large Pipe Breaks in a BWR.

fy (8), the cladding temperature turnaround (9) results from the initiation of r cladding temperature history $\left(8^{\prime}\right)$, the effects of metal-water reaction energy are perature rise prior to the event of flooding $\left(9^{\prime}\right)$.

nts arre depicted by dashed lines in Figure: B-3. The pressure is sech to decrease? culation line break. Sines steam venting is taking place at a higher region of the muins high and all recireulation line systems continue to operate. Significant core low eventually decreases as the pressure decay causes the recirculating mechanical to provide reasonable core flow and at least sufficient steam cooling to the core. it nearly all the stored energy within the fuel is removed until, at the worst case, he heat transfer required to keep the cladding temperatures near the coolant ?adding temperature begins to rise as a result of the small amount of remaining time most of the fluid lost from the system as a result of a steam line brcak has ction of liquid having insufficient enthalpy to flash remains in the lower plenum. yer plenum to the bottom of the core and offect early turnover of the cladding ss than for the recirculation line break. The general behavior of the fuel cladding, ent are sufficiently similar to those of a PWR that additional discussion is 


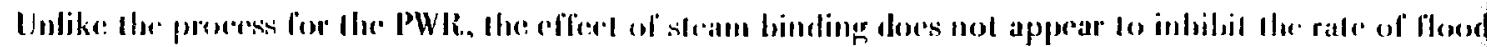

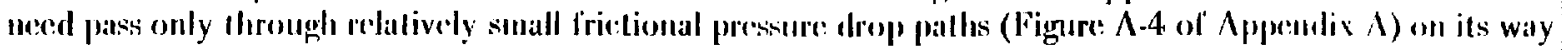

Finure B-4 presents the calculated peak cladding temperalure as a function of brealk arra for stoam linc breaks for two separate single lailure conditions in a contemporary BWR B-I. One case consillers failure of considers failure of a diesel generator. These graphs are considered representative of a single-lailure erilerion a chadding temperature and should not be considered to be restrietive in defining the capability of a syste systems. As would be expected, a general trend toward higher peak cladding temperatures oceurs as break smallest breaks, no core heatup oecurs. The exact shapes and magnitudes of the temperalure curves for this depend to a large extent on such factors as the analytical techniques used in the calculations, assumpt correlations, and the particular single failure condition considered.

\section{REFERENCE}

B-1 Core Standby Cooling Systems for the General Electric 1969 BWR Standard Plants, NEDO-10183

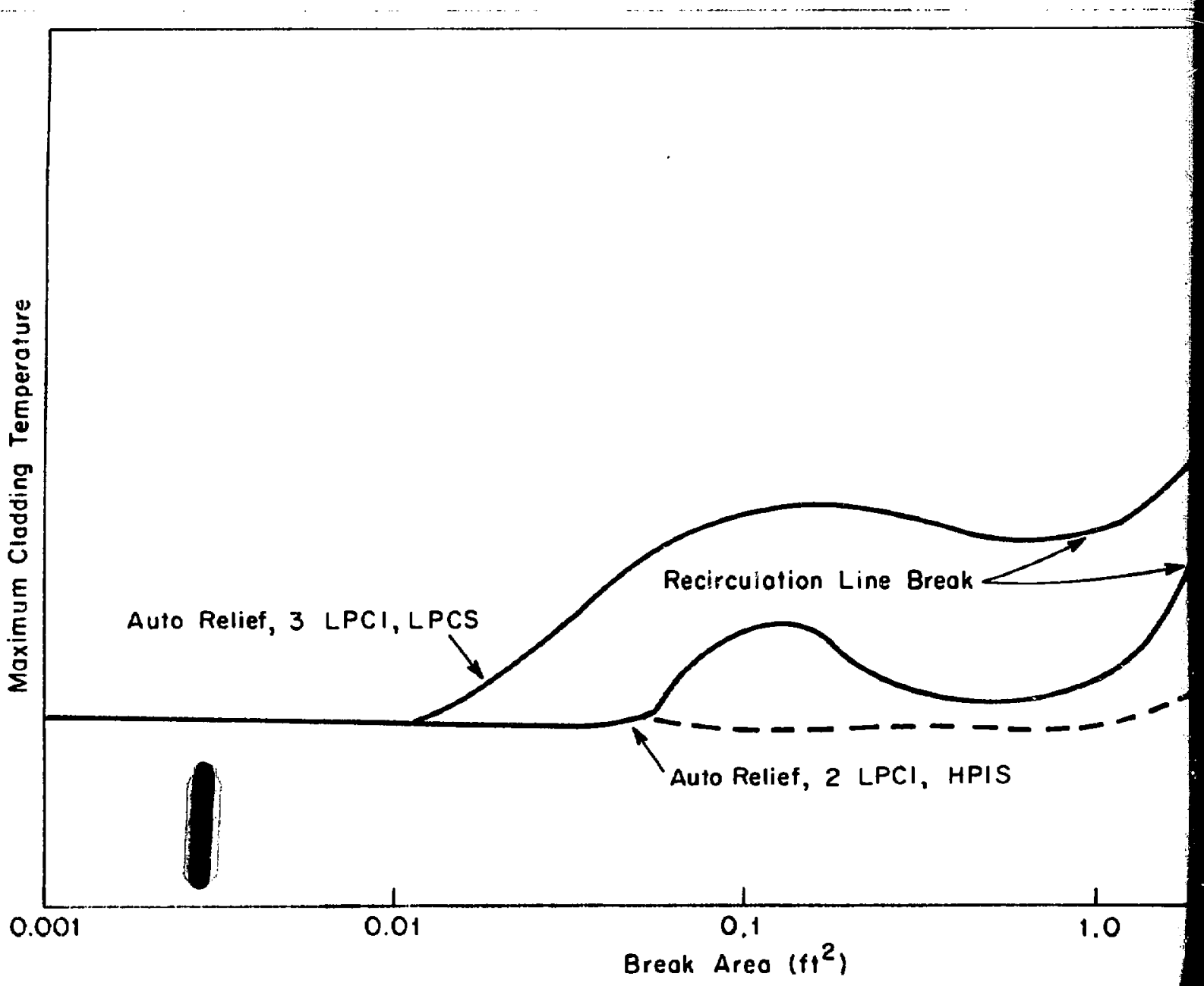

Figure B-4. Generalized Comparison of Maximum Cladding Temperature for Various Pipe in a BWR. 


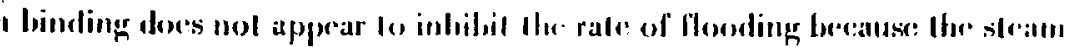
a drop pallos (Figure $\Lambda .4$ of $\Lambda$ ppendix $\Lambda$ ) on its way lo the break.

emperature as a function of break area for steam line and receireul:ation line ontemporary BWR B-1. One case considers failure of the IIPCS; the oltere onsidered representative of a singlr-failure erilerion approach lo maximum be restrictive in defining the capability of a system or combination of higher peak cladding temperatures oceurs as break arcas increase. For the ss and magnitudes of the temperalure curves for this type of representation ytical techniques used in the calculations, assumptions on heat transfer onsidered.

Flectric 1969 BWR Standard Plants, NEDO-10183 (May 1.970).
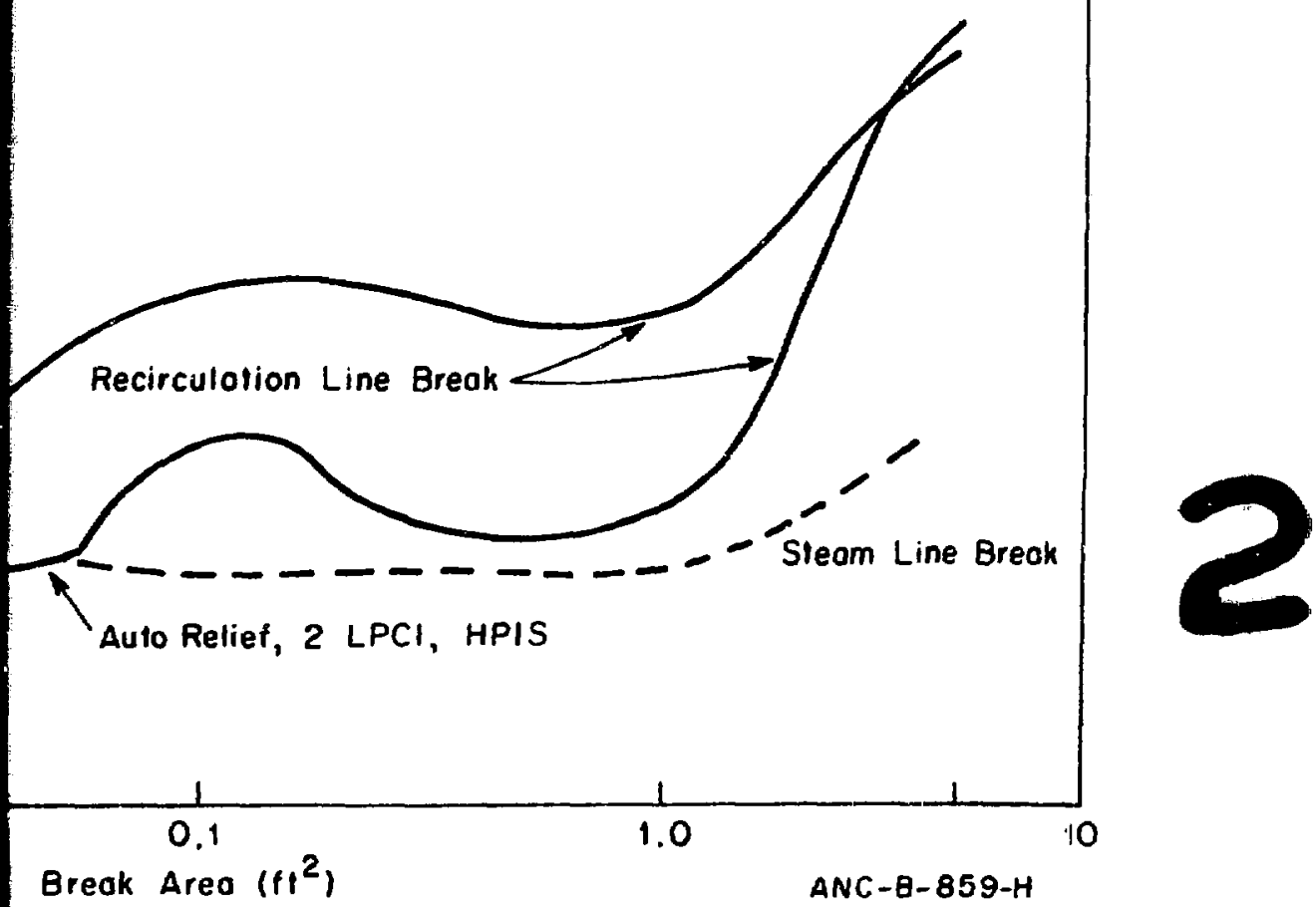